\title{
The Illegitimate President: Minority Vote \\ Dilution and the Electoral College
}

\author{
Matthew M. Hoffman ${ }^{\dagger}$
}

\section{CONTENTS}

I. INTRODUCTION ....................... 936

II. RAcial Politics AND THE Electoral SYSTEM . . . . . . . . . . . 942

A. The Constitutional Framework . . . . . . . . . . . . . . . . 942

B. The Winner-Take-All System . . . . . . . . . . . . . . 945

C. Race, Presidential Politics, and the Winner-Take-All Rule . . . 949

1. Strom Thurmond and the "Dixiecrat" Campaign of 1948.950

2. The Free Elector Movement of 1960 . . . . . . . . 954

3. The Wallace Campaign of 1968 and the Rise of the Republican South . . . . . . . . . . . . . 957

4. Racial Politics and Present-Day Campaigns ........ 959

III. APPLICATION OF THE VOTING RIGHTS ACT TO THE ELECTORAL SYSTEM $\ldots \ldots \ldots \ldots$. . . . . . . . . . 962

A. Constitutional Authority . . . . . . . . . . . . 965

B. Statutory Authority . . . . . . . . . . . . . . . . . 974

IV. THE $\S 2$ ANALYSIS . . . . . . . . . . . . . . . . . . . 978

A. Legal Standards . . . . . . . . . . . . . . . . . . 979

1. Numerosity and Geographical Compactness . . . . . . 980

2. Political Cohesion .................... 984

3. White Bloc Voting ................. 988

4. The Totality of the Circumstances . . . . . . . . . . 995

B. Some Specific Examples ................... . 999



2. California ........................ 1002

$\dagger$ A.B., Harvard University, 1991; J.D., Yale Law School, 1995. I would like to thank a number of people whose comments and suggestions either directly or indirectly contributed to the development of this Article. In alphabetical order, they are: Ian Ayres, Richard Engstrom, Gerald Hebert, Pamela Karlan, Allan Lichtman, Burke Marshall, Joseph R. Palmore, Richard Pildes, Tricia Small, and Brenda Wright. Of course, none of these people should be held responsible for anything that I say. 
3. Illinois ....................... 1005



V. Remedies . . . . . . . . . . . . . . . . . . . 1010

A. The Congressional-District System . . . . . . . . . . . 1011

B. The Proportional System . . . . . . . . . . . . . . 1013

VI. RETHINKING WINNER-TAKe-ALL: SOME Possible EFFECTS $\ldots 1015$

A. Political Realignments . . . . . . . . . . . . . . . 1016

B. Biases, "Wrong Winners," and the Direct-Vote Alternative .. 1019

VII. ConcLusion . . . . . . . . . . . . . . . . . . 1020

The Electoral College has served its purpose under the Constitution for more than 150 years. It has operated quietly, smoothly and effectively-so much so that the general public is hardly aware of its existence. But it is there behind the scenes as a great bulwark of our representative form of government.

$$
* * *
$$

Neither the Negroes nor any of the groups which support them can alone, or in conjunction with each other, give assurance of control of a single vote in the Electoral College.'

\section{INTRODUCTION}

African-American voters in the United States have never held much sway in the election of the President. Although they often exert considerable influence in presidential primaries, their status as a racial minority ensures that, in the general election, their voices are frequently drowned out by the majority. In the electoral college, where the President is actually chosen, the preferences of minority voters count for almost nothing. The overwhelming majority of states provide that the presidential candidate who wins the popular vote in the state claims all of its electoral votes. Thus, so long as minority voters have different political preferences than the majority-a fact that is almost selfevident in many parts of the country - their votes will be virtually meaningless in the final selection of the President. This problem is perhaps most acute in the South, where the political disparities between African-American and white

1. Charles Wallace Collins, Whither Solid South? A Study in Politics and Race RELATIONS 279, 258 (1947). 
voters have historically been most pronounced. ${ }^{2}$ As one pair of commentators has recently noted, African-American voters in the South "have had little more influence on most modern presidential general elections than Bulgarians. Their votes, although technically cast, have not usually counted."

This Article examines the mechanics of this phenomenon and advances a novel legal claim with potentially far-reaching implications for the American political system. I contend that many states-including California, New York, Illinois, and much of the South-may be conducting presidential elections in a manner prohibited by federal law. Specifically, I argue that, in these states, the so-called "winner take all" system of choosing presidential electors (sometimes referred to as the "general ticket" or "unit vote" system) ${ }^{4}$ potentially violates $\S 2$ of the Voting Rights Act of 1965 , which, as amended in 1982, prohibits electoral systems that limit or dilute the ability of racial and language minorities to elect candidates of their choice. ${ }^{5}$

As this Article will demonstrate, voting in presidential elections is highly polarized along racial lines. Consequently, choosing presidential electors through the winner-take-all system results in a paradigmatic example of the kind of discrimination that $\S 2$ was meant to eliminate. Its all-or-nothing character prevents the formation of politically cohesive blocs of AfricanAmerican voters-and possibly blocs of other minority voters as well-even in states where they clearly could choose one or more electors under an alternative system. ${ }^{6}$

2. For a recent study that thoroughly documents the persistence of racially polarized voting patterns in eight Southern states, see QUIET REVOLUTION IN THE SOUTH: THE IMPACT OF THE VOTING RIGHTS ACT 1965-1990 (Chandler Davidson \& Bernard Grofman eds., 1994) [hereinafter QuiEr REvoluTION].

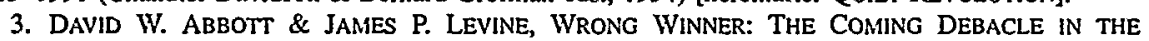
Electoral College 94 (1991); see also NeIL R. PEIRCE \& LAWrence D. LONGLeY, The PEOPLE'S President: The Electoral College in AMERICAN History and the DiReCt Vote Alternative 127-30 (rev. ed. 198I) (describing electoral college bias against African-Americans based on their geographical distribution).

4. Judith Best has implicitly suggested that the term "winner-take-all" has pejorative connotations. See Judith BEST. THE CASE AgAinst DiRECT ElECTION OF THE PRESIDENT: A DEFENSE OF THE Electoral COLLEGE 27 (1975). I disagree. This Article uses the term "winner-take-all" because it accurately describes the way in which the prevailing electoral system functions: The winner of a state takes all of that state's electoral votes. By contrast, the terms "general ticket" and "unit vote" seem vague and confusing.

5. See 42 U.S.C. $\$ 1973$ (1994).

6. The proper definition and labeling of minority groups present thorny problems in any context, but particularly in the context of voting behavior, where individual preferences must be analyzed in the context of group behavior. For the sake of simplicity, this Article focuses primarily on the behavior of AfricanAmericans, a group that is relatively well defined within the context of American society. I use the terms "African-American" and "black" interchangeably to refer to that group of people identified in the U.S. census as non-Hispanic black.

At times, however, this Article refers to other racial or ethnic groups protected by the Voting Rights Act, including Asian-Americans and Hispanics. I use the term "Hispanic" to refer to the group of people classified by the census as Hispanic, regardless of race. I have chosen this term, rather than alternate terms like "Latino" or "Chicano," because it emphasizes the linguistic link between the members of this large and diverse minority group, rather than any geographic or ethnic characteristics. Readers should be aware, however, that "Hispanic" is a catchall term comprising several ethric groups, including Cuban-Americans, Mexican-Americans, and Puerto Ricans, and that Hispanics may be of any race. 
The key to understanding this phenomenon is to recognize that, under the Constitution, the people do not vote directly for presidential candidates. Instead, they vote for slates of candidates for the office of presidential elector. Under the winner-take-all rule, the slate that receives the most votes statewide wins the election in that state. Although this method of election is not constitutionally required, it is currently used by forty-eight states and the District of Columbia. Since the slates are chosen by the political parties that nominate the presidential candidates, the net effect is to give the candidate who wins the statewide popular vote all of that state's electoral votes. Political minority groups are thus unable to choose even a single presidential elector. In the memorable phrase of Justice Douglas, their ballots are "counted only for the purpose of being discarded."

As a point of comparison, consider the following hypothetical. Suppose that a state with a large minority population decided to adopt the winner-takeall rule for elections to the House of Representatives-as, under the Constitution, states are entitled to do. ${ }^{8}$ Under this system, each party would nominate a slate of congressional candidates, and voters would simply vote for one party or the other. In that case, the majority faction in the state would be able to choose all of the state's congressional representatives in the House and the Senate. If voting were polarized along racial lines, it seems evident that the votes of racial minorities would be almost worthless, and that they would be virtually unrepresented in the national legislature. Such a system would seem patently unfair-and yet it is precisely the same system that we currently countenance for the selection of presidential electors.

Electors, of course, exercise a very different political function than members of Congress. Most voters are scarcely aware of their existence. Those few who do understand how the electoral system functions tend to dismiss the role of the electors as a mere formality. In a sense, these observations are valid. After all, electors customarily do not exercise any independent judgment, or perform any of the other tasks that one typically expects of elected representatives. Yet it is important to recognize that electors do perform a representative function. They cast ballots for President on behalf of the people of their states-or, more precisely, on behalf of those voters who chose them.

I use the term "Asian-Americans," by contrast, to refer to the group of people classified by the census as Asians or Pacific Islanders. Unlike Hispanics, the U.S. Census Bureau considers Asians and Pacific Islanders to be an identifiable race. Again, however, the reader should be aware that Asian-Americans are not a unitary group, but rather an aggregation of several ethnic and national groups.

7. Gray v. Sanders, 372 U.S. 368, 381 n.12 (1963). Justice Douglas was describing Georgia's countyunit method, similar to the electoral college system, for counting votes in a Democratic primary election for U.S. Senator and for statewide offices.

8. Although the Constitution permits at-large elections for House seats, a federal statute now requires election from districts. See 2 U.S.C. $\$ 2 c$ (1985) (requiring single-member congressional districts for all states with more than one House seat); see also discussion infra note 143 and accompanying text. 
Voters who cannot participate effectively in choosing the electors realistically have no voice in selecting the President.

This Article documents the severe racial polarization in American presidential elections in the 1980s and 1990s through a detailed analysis of primary and general election exit poll data. The fact that black and white voters consistently tend to prefer different candidates is readily apparent from national survey data. Exit polls indicate that, in the past five presidential elections, between $82 \%$ and $90 \%$ of black voters nationwide have voted for the Democratic candidate. By contrast, white voters have preferred the Republican candidate in every election since 1976, by margins ranging from $2 \%$ in 1992 to $29 \%$ in $1984 .^{9}$

Through an original analysis of exit poll data, this Article demonstrates that similar patterns of racial polarization hold true at the statewide level as well. This analysis also demonstrates that these divergent patterns cannot be explained on mere partisan grounds. Indeed, polls indicate that similar patterns hold true even among independent voters and among members of the same political party. ${ }^{10}$ Furthermore, the results of the 1984 and 1988 presidential primaries-in which an African-American candidate, Jesse Jackson, staged prominent bids for the Democratic nomination-clearly indicate that even in intraparty contests, black and white voters have distinct political preferences. Jackson was the overwhelming favorite among African-American Democrats in those races, frequently capturing more than $90 \%$ of the black vote, but he seldom received more than $10 \%$ to $15 \%$ of the white vote.

In fact, these disparities are not surprising, given the prominent role that race and race-related issues play in modern American presidential politics. Racial appeals, some direct and some more covert, have been a recurring feature of presidential campaigns during the last fifty years, from the "Dixiecrat" campaign of Strom Thurmond in 1948 to the third-party challenge of arch-segregationist George Wallace in 1968 to the infamous "Willie Horton" advertisements of George Bush's campaign in 1988.

Such carefully orchestrated racial appeals virtually ensure that voting in presidential elections will be polarized along racial lines. And the winner-takeall system works in conjunction with that polarization to shut the voices of African-American voters out of the political process. As noted above, this problem is most acute in the states of the former Confederacy, where racially polarized voting is particularly severe. In these states, African-American voters have little or no hope of choosing even a single member of the electoral

9. See Portrait of the Electorate, N.Y. TIMES, Nov. 5, 1992, at B9 (summarizing exit poll results from 1976-1992 and finding margin of 29\% in 1984); see also ABC News Exit Poll Results, WaSH. POST, Nov. 9. 1988, at A34 (finding margin of $11 \%$ in 1988); ABC News Exit Poll: Voting for President, WASH. POST, Nov. 7, 1984, at A40 (finding margin of $27 \%$ in 1984).

10. See discussion infra Subsection IV.A.3. 
college. ${ }^{11}$ Although they can step into a booth and pull a lever, their votes never really count. With respect to presidential elections, they are completely disenfranchised-just as they were for so many years in the eras of slavery and segregation.

The argument that the current electoral system tends to disadvantage voters who are members of political minority groups has been made many times before. ${ }^{12}$ Several legal challenges based on the Equal Protection Clause of the Fourteenth Amendment have fallen on deaf ears. ${ }^{13}$ The argument in this Article, however, rests on an alternative theory that addresses the system's inequities with respect to voters who are members of racial minority groups. The thread of this argument may seem initially to run counter to recent trends in voting rights law that have limited the reach of the Voting Rights Act. ${ }^{14}$ As this Article will demonstrate, however, application of the Voting Rights Act to the electoral college is particularly appropriate in light of these decisions because it does not require states to employ any race-conscious remedies.

In Part II of this Article, I outline the constitutional framework and historical roots of the electoral system and describe the legal mechanisms by which the winner-take-all system operates. I then turn to a discussion of some comparatively recent history, focusing on the efforts of various politicians to advance racist agendas, either explicitly or covertly, through the manipulation of the electoral college. Thurmond's 1948 campaign and Wallace's 1968 campaign are the clearest examples of this phenomenon. This Article contends that the legacy of these efforts lives on in the present day.

11. To be sure, the African-American candidate of choice, Bill Clinton, did win four Southern states in 1992: Arkansas, Georgia, Louisiana, and Tennessee. That apparent success does not necessarily mean, however, that African-American voters have a realistic opportunity to elect candidates of their choice in those states. The vote-dilution inquiry focuses on patterns of voting over several elections, rather than on the outcome of individual elections, and recognizes that "special circumstances . . . may explain minority electoral success in a polarized contest." Thornburg v. Gingles, 478 U.S. 30, 57 (1986).

Bill Clinton's Southern victories in 1992 must be analyzed in light of at least two such "special circumstances." First, he ran in an unusual, three-way race. Because the white vote was splintered among three candidates, the influence of black voters, who supported Clinton in overwhelming numbers, was correspondingly greater. Second, Arkansas and Tennessee are, respectively, the home states of Clinton and his vice-presidential running mate, Al Gore. Thus the Democratic ticket had a natural edge there.

To the extent that Clinton's victory in Louisiana and Georgia is not reflective of any special features of the three-way race, it might indicate that African-Americans have a viable opportunity to elect candidates of their choice. These results must be viewed in conjunction with the results of other elections, however. See id. at 49 (holding that legally significant vote dilution requires that "a bloc voting majority must usually be able to defeat candidates supported by a politically cohesive, geographically insular minority group").

12. See, e.g., Michael J. O'Sullivan, Artificial Unit Voting and the Electoral College, 65 S. CAL. L. REV. 2421, 2431 (1992).

13. In 1966, the State of Delaware filed an original-jurisdiction action in the Supreme Court alleging, among other things, that the winner-take-all system violated the Equal Protection Clause by "canceling" the votes of political minorities. See Brief for Plaintiff at 56-68, Delaware v. New York. 385 U.S. 895 (1966) (No. 28 Original). The Court declined to hear the case. In other cases, courts have explicitly rejected equal protection challenges to the winner-take-all system. See Penton v. Humphrey, 264 F. Supp. 250 (S.D. Miss. 1967); Gray v. Mississippi, 233 F. Supp. 139 (N.D. Miss. 1964).

14. See, e.g., Miller v. Johnson, I15 S. Ct. 2475, 2485-94 (1995) (finding Georgia's race-based districting invalid absent compelling state interest). 
Part III then turns to a discussion of $\S 2$ of the Voting Rights Act and its application to the electoral system. After a brief overview of the statutory language and its origin, $I$ argue that $\S 2$ places limits on state discretion over the mode of appointment of presidential electors. First, I assert that Article II of the Constitution, which appears to give states exclusive control over the appointment of electors, does not preclude enforcement of the Voting Rights Act. Second, I argue that minority vote dilution in the selection of presidential electors falls within the scope of the practices that $\$ 2$ prohibits.

In Part IV, I employ the analytical framework developed by the federal courts in Thornburg $v$. Gingles ${ }^{15}$ and subsequent cases in an attempt to identify which states might be vulnerable to a $\S 2$ challenge. This part also includes detailed analyses of voting behavior in four states with differing demographic and political characteristics: Alabama, California, Illinois, and New York. Part V then discusses the comparative strengths and weaknesses of two remedial options that states might employ as alternatives to the winnertake-all system. Finally, Part VI briefly discusses the effects that a move away from the winner-take-all system might have on the structure of American politics.

At the outset, I wish to make it clear that the purpose of this Article is not to advocate any constitutional amendment that would modify or abolish the electoral system. ${ }^{16}$ Instead, this Article considers the electoral system within its current constitutional framework. My goal is simply to examine the methods the states currently use to administer that system in light of the national standards in $\S 2$ of the Voting Rights Act. My analysis would be incomplete, however, if I did not point out that a fair and nondiscriminatory electoral system might well be superior to the alternative most frequently proposed by modern-day critics of the current system: direct election of the President by the people. More than 200 years ago, the Framers adopted the electoral system in an effort to ensure a rough balance of interests between various constituencies in the selection of our nation's Chief Executive. Properly administered, the electoral system might help us to achieve a similar balance today.

15. 478 U.S. 30 (1986).

16. For arguments in favor of abolishing the electoral system and replacing it with a direct vote for President, see ABBOT \& LEVINE, supra note 3; PEIRCE \& LONGLEY, supra note 3. For arguments in favor of maintaining the current system, see BEST, supra note 4; MARTIN DIAMOND, THE ELECTORAL COLLEGE AND THE AMERICAN IDEA OF DEMOCRACY (1977). See also AlEXANDER M. BICKEL, THE NEW Age OF POLITICAL Reform: THE Electoral College, THE CONVENTION, AND THE PARTY SySTEM 8-20 (1968) (discussing and critiquing arguments in favor of abolishing the present system). 


\section{RACIAL POLITICS AND THE ELECTORAL SYSTEM}

To comprehend fully the way in which the winner-take-all system dilutes minority voting strength, one must first come to terms with a simple, though little-recognized, historical fact. For nearly fifty years, white Southern politicians have repeatedly and deliberately attempted to manipulate the machinery of the electoral college to influence national policy on race and civil rights. This part details that history, with particular emphasis on the presidential elections of 1948, 1960, and 1968-each of which saw a significant bloc of Southern electoral votes cast for an openly racist third-party candidate. A full consideration of this history is impossible, however, without some understanding of the complex array of constitutional, federal statutory, and state-law provisions that govern the selection of presidential electors. Accordingly, Section A discusses the historical roots of the electoral system and the constitutional framework in which it operates, while Section B examines the mechanics of the winner-take-all system and explores the reasons for its dominance. Section $\mathrm{C}$ then analyzes the peculiar interaction of race, presidential politics, and the electoral college in the latter half of the twentieth century.

\section{A. The Constitutional Framework}

To anyone who is at all familiar with modern American presidential elections, what is perhaps most striking about the Constitution's discussion of the electoral college is that it makes no mention of a "winner-take-all" rule. Indeed, the constitutional text makes no explicit provision for the election of the President by the people at all. Instead, Article II provides simply that:

Each State shall appoint, in such Manner as the Legislature thereof may direct, a Number of Electors, equal to the whole Number of Senators and Representatives to which the State may be entitled in the Congress: but no Senator or Representative, or Person holding an Office of Trust or Profit under the United States, shall be appointed an Elector. ${ }^{17}$

In short, the Constitution simply provides that the President will be chosen by a group of presidential electors and allocates the electors among the states. The choice of how the electors are appointed is explicitly left to the legislatures of the individual states.

17. U.S. CoNST. art. II, $\S 1$, cl. 2. 
Currently, the states are authorized to appoint a total of 538 presidential electors. ${ }^{18}$ People frequently speak of this group as the "electoral college," but, in reality, that term is something of a misnomer. In fact, it is hard to imagine any body less collegial. Strictly speaking, the "electoral college" is not a single body at all, but rather an aggregation of fifty-one different bodies, each of which meets and votes separately. This configuration is not a historical accident, but a well-considered constitutional requirement. Both Article II and the Twelfth Amendment specifically mandate that the electors meet to cast their ballots "in their respective states." In part, this requirement may be seen as a holdover from the early days of the Republic, when interstate travel was time-consuming, expensive, and potentially dangerous. As a practical matter, it was much easier for the electors to travel to their state capitals than to travel to the nation's capital. But the requirement that the electors meet separately also served an important political function. Article II grants Congress power to determine when the electors vote, but explicitly mandates that they must all vote on the same day. ${ }^{20}$ By spreading the electors out over a large geographic area and requiring them to vote at the same time, the constitutional scheme theoretically minimizes the opportunity for individual factions or interest groups to lobby for votes among the electors in an attempt to influence the choice of President. ${ }^{21}$

It was a desire to avoid precisely this kind of politicking that led the Framers to adopt the electoral scheme..$^{22}$ At the time, it was common practice for state legislatures to choose governors, and several delegates at the

18. Today, the size of the House of Representatives is set by law at 435 members. See generally 2 U.S.C. § 2 a (1994) (providing reapportionment method whereby total number of House members remains constant). There are 50 states, each with two Senators. The states are thus authorized to choose a total of 535 presidential electors. In addition, the Twenty-Third Amendment allows the District of Columbia to appoint "[a] number of electors . . . equal to the whole number of Senators and Representatives in Congress to which the District would be entitled if it were a State, but in no event more than the least populous state." U.S. CONST. amend. XXIII, § 1. The least populous state is Wyoming, which has two Senators and one Representative in Congress. Consequently, the District is authorized to appoint three electors, bringing the grand total to 538 .

19. U.S. CONST. art. II, § 1, cl. 3; id. amend. XII.

20. See id. art. II, $\$ 1, \mathrm{cl} .4$ ("The Congress may determine the Time of chusing the Electors, and the Day on which they shall give their Votes; which Day shall be the same throughout the United States."). 1987):

21. See THE FEDERALIST No. 68, at 393-94 (Alexander Hamilton) (Isaac Kramnick ed., Penguin Books

[A]s the electors, chosen in each State, are to assemble and vote in the State in which they are chosen, this detached and divided situation will expose them much less to heats and ferments, which might be communicated from them to the people, than if they were all to be convened at one time, in one place.

... The business of corruption, when it is to embrace so considerable a number of men requires time as well as means. Nor would it be found easy suddenly to embark them, dispersed as they would be over thirteen States, in any combinations founded upon motives which, though they could not properly be denominated corrupt, might yet be of a nature to mislead them from their duty.

22. For a detailed account of the process by which the Constitutional Convention settled on the electoral scheme, see TADAHISA KURODA, THE ORIGINS OF THE TWELFTH AMENDMENT: THE ELECTORAL COLLEGE IN THE EARLY RePUBLIC, 1787-1804, at 7-15 (1994). 
Constitutional Convention initially argued that, in keeping with that practice, Congress should choose the President. ${ }^{23}$ James Madison and others vigorously objected to that idea, arguing that it would make the President entirely beholden to the Congress that selected him. ${ }^{24}$ The use of presidential electors, who served no function other than to elect the President, would, the Framers believed, reduce the opportunity for "cabal, intrigue, and corruption."25 Article II reflects this concern over political corruption and deal making in other places as well. For example, it specifically commands that "no Senator or Representative, or Person holding an Office of Trust or Profit under the United States, shall be appointed an Elector." ${ }^{26}$ In theory, then, the electors were meant to form an independent body, beholden to no one, that could "enter upon the task free from any sinister bias."27

The concept of an "electoral college" is misleading in another way. Unlike, say, the Vatican's College of Cardinals, which keeps voting until it settles on a Pope, the electoral vote is a one-time proposition. Once the electors cast their votes, the statewide tallies are sealed and sent to Washington, where the President of the Senate opens them and counts them "in the presence of the Senate and House of Representatives." 28 If no candidate receives a majority, the House of Representatives chooses the President from among "the persons having the highest numbers [of electoral votes] not exceeding three." 29 This backup plan is a variation of the legislative-selection plan that the Framers had earlier rejected-but with a twist. In a House contingency election, the individual Members do not vote. Instead, Article II specifies that the House will choose the President by majority vote of the states, with the delegation from each state getting a single vote. ${ }^{30}$

Strange as this system may sound to the modern ear, the electoral scheme was well received initially, even by some vigorous opponents of the Constitution. $^{31}$ Supportive comments from Anti-Federalists led Alexander Hamilton to crow in Federalist No. 68 that "if the manner of [presidential election] be not perfect, it is at least excellent. It unites in an eminent degree all the advantages the union of which was to be desired." ${ }^{\text {32 }}$ As it happened,

23. See id. at 8 .

24. Michael J. Glennon, When no Majority Rules: The Electoral College and PRESIDENTIAL SUCCESSION 7-8 (1992). The delegates also had difficulty agreeing whether, in a congressional-selection scheme, the Senate and the House would make their choice by joint vote, with the two houses meeting as a single body, or by concurrent vote, with each house voting separately. KURODA, supra note 22 , at $13-14$.

25. THE FEDERALIST No. 68, at 393 (Alexander Hamilton) (Isaac Kramnick ed., Penguin Books I987).

26. U.S. CONST. art. II, $\S 1$, cl. 2.

27. THE FEDERALIST No. 68, at 394 (Alexander Hamilton) (Isaac Kramnick ed., Penguin Books 1987).

28. U.S. CONST. amend. XII.

29. Id. It is unclear from the constitutional text whether the House must consider the top three candidates, or whether it can limit itself to two.

30. See id. art. II, \& 1, cl. 3.

31. See KURODA, supra note 22 , at 17,21 .

32. THE FEDERALIST No. 68, at 393 (Alexander Hamilton) (Isaac Kramnick ed., Penguin Books 1987). 
Hamilton's enthusiasm was entirely uncalled for. The electoral scheme enacted by the Framers was so deeply flawed that a constitutional amendment-the Twelfth-was needed to shore up the system after only the fourth presidential election. ${ }^{33}$ Rather than abolishing the electoral system, however, the framers of the Twelfth Amendment were content merely to tinker with it. The basic framework survives to this day.

\section{B. The Winner-Take-All System}

Although the winner-take-all rule is a familiar feature of modern-day presidential elections, it is not required by the Constitution, and states are free to adopt alternative systems. One can imagine a number of techniques by which legislatures might exercise their constitutional authority. The simplest of these is direct appointment, in which the legislature simply names the electors on its own, without holding a popular election. This was a common technique in early presidential elections; even as late as 1820 , nine states still chose presidential electors by legislative appointment. ${ }^{34}$

Alternatively, the legislature might exercise its power of appointment by putting the choice to a popular vote. A number of such schemes are possible, of which three are particularly important for the purposes of this Article. The first is the winner-take-all, or general-ticket, system. In this system, each

33. The problem was that under the original electoral scheme prescribed by Article II, each elector voted for two different candidates for President, instead of one candidate for President and one for Vice President. The candidate with the most votes was elected President, and the runner-up became Vice President. As long as George Washington remained the clear national consensus choice for President, this system worked fine. But when Washington announced his intention to retire and the leaders of the nascent Federalist and Republican parties began vying to succeed him, a problem emerged. Because of the undifferentiated vote, a party had to manipulate the electoral machinery carefully to ensure that its vicepresidential candidate did not defeat its presidential candidate. Certain electors had to be directed not to cast their votes for their party's vice-presidential candidate to avoid a tie. That practice, however, created the risk that the opposing party's presidential candidate would be elected Vice President. This is precisely what happened in the election of 1796. John Adams, the Federalist candidate, won the election, but his running mate, Thomas Pinckney, lost by nine votes to Adams's Republican opponent, Thomas Jefferson. Thus Adams became President, and his chief rival, Jefferson, became Vice President.

The defects in the system became even more apparent in the election of 1800 . In that campaign, Jefferson and his running mate, Aaron Burr, ran against Adams and his new vice-presidential candidate, Charles Pinckney, the brother of Thomas. The Republicans had a clear majority in the electoral college. One elector in South Carolina, however, was instructed not to vote for Burr, to avoid the possibility of a tie. The South Carolina elector failed to carry out these instructions, however, with the result that Jefferson and Burr each received 73 electoral votes, forcing a contingency election in the House. Although the Republicans had won a majority in the new Congress, the lame duck Federalist House controlled the presidential selection. After bitter contention and 36 ballots, the House finally settled on Jefferson. This tumultuous affair led to adoption of the Twelfth Amendment, which reformed the system by providing that, in future elections, the electors would vote separately for President and Vice President.

For a detailed account of the early presidential elections and the adoption of the Twelfth Amendment, see KURODA, supra note 22. See also GLENNON, supra note 24, at 14-15 (discussing election of 1800 and Twelfth Amendment); PEIRCE \& LONGLEY, supra note 3, at 33-44 (discussing elections of 1792, 1796, and 1800 and Twelfth Amendment).

34. PEIRCE \& LONGLEY, supra note 3, at 247. Florida also adopted legislative selection for the 1868 election, and Colorado did the same for the 1876 election. GLENNON, supra note 24, at 13. 
political party nominates a slate of candidates for the office of presidential elector. Each voter then casts a vote for one of the slates. All of the members of the slate that receives the most votes statewide are then elected.

Another alternative is frequently described as the "district system," but will be referred to in this Article as the "congressional-district system" to distinguish it from a "pure" system of single-member districts. In a pure single-member-district scheme, a state would be divided into a number of districts equal to the number of electors it appoints, and each district would choose one elector. Under the congressional-district system, by contrast, two electors are chosen at large to represent the state, and one additional elector is chosen for each congressional district. As in the winner-take-all system, the parties nominate a slate of candidates for the presidential-elector positions. Once again, voters do not vote for individual candidates, but rather for one slate or another. The difference lies in the way the votes are counted. A vote for one party's slate is counted as a vote for that slate's two statewide candidates and the slate's candidate for that district. The winning candidates are the two at-large candidates who receive the most votes statewide, and the district candidates who receive the most votes within each district. Thus, one state may elect candidates from two or more different party slates.

A third alternative will be referred to in this Article as the "proportional system." Under this system, the parties would choose slates of candidates for elector and rank them in order of preference. Again, voters would not vote for individual electors, but for party slates. Under this system, however, the electoral seats would be allocated among the parties in proportion to the statewide vote. Thus, if a state had ten electoral votes, and the Republican presidential candidate received $60 \%$ of the vote, while the Democratic presidential candidate received $40 \%$ of the vote, the first six electoral candidates from the Republican slate and the first four from the Democratic slate would be appointed as electors. ${ }^{35}$

In early presidential elections, the congressional-district system and the winner-take-all system were both quite common ${ }^{36}$ By 1832 , however, the winner-take-all system had become predominant. The only states that did not use it were South Carolina, which retained the legislative-appointment system until 1860, and Maryland, which retained the congressional-district system. ${ }^{37}$

35. The term "proportional system" is also used to describe a reform proposal sponsored in the Senate by Massachusetts Senator Henry Cabot Lodge and in the House of Representatives by Texas Representative Ed Gossett in 1950. Under that plan, the individual electors would have been abolished, but each state would have retained its electoral votes. Those electoral votes would have been divided among the various candidates based on the statewide vote, with the resulting possibility that candidates might receive fractions of electoral votes. See PEIRCE \& LONGLEY, supra note 3, at 289-90 (providing text of proposed constitutional amendment). Since this version of the proportional plan requires a constitutional amendment, it is beyond the scope of this Article.

36. Id. at 247.

37. See id. at $248-49$ (describing methods used in various states from 1789 to 1836 ). 
The growth of the winner-take-all system is generally attributed to two factors. First, the system tends to benefit the political party in power in any given state by ensuring that the minority party will get none of that state's electoral votes. More generally, the system tends to favor established political parties over smaller, fringe parties and independent candidates. ${ }^{38}$ Second, use of the winner-take-all system tends to increase the voting power of citizens within a state. ${ }^{39}$ Consequently, once some of the states began to adopt the winner-takeall scheme, voters in the other states were at a competitive disadvantage, which placed pressure on their legislatures to adopt the winner-take-all method. ${ }^{40}$

With a few variations, the winner-take-all system is currently in use in forty-eight of the fifty states, as well as the District of Columbia. ${ }^{41}$ The remaining two states, Maine and Nebraska, use congressional-district systems for appointing electors. ${ }^{42}$ The Supreme Court has expressly held that both methods are constitutional. ${ }^{43}$

How precisely does the statutory winner-take-all system work? With minor variations, the system is essentially the same in all states. Take, for example, the State of Alabama. Alabama law prescribes that presidential candidates can be nominated by the national convention of a political party or a petition signed by 5000 qualified Alabama voters. ${ }^{44}$ To get on the ballot, the party or other organization must deliver a certificate of nomination, or, in the alternative, its nominating petition, to the Alabama secretary of state. ${ }^{45}$ Accompanying the petition must be a list of the names and addresses of

38. GLENNON, supra note 24 , at 12.

39. This observation is based upon a mathematical analysis of the electoral college performed in the 1960 s, which also demonstrated that citizens in larger states tend to have more infiuence over the outcome of elections in a winner-take-all system than they would have in a direct election. See John F. Banzhaf III, One Man, 3.312 Votes: A Mathematical Analysis of the Electoral College, 13 VILL. L. Rev. 304, 315-16 (1968).

40. See Akhil Reed Amar \& Vik Amar, President Quayle?, 78 VA. L. Rev. 913, 927-28 (1992) (attributing predominance of winner-take-all system to "prisoners' dilemma" faced by states).

41. GLENNON, supra note 24 , at 12.

42. See ME. REv. StAT. ANN. tit. 21-A, § 802 (West 1994) ("One presidential elector shall be chosen from each congressional district and 2 at large."); id. tit. 21-A, § 805(2):

The presidential electors at large shall cast their ballots for the presidential and vice-presidential candidates who received the largest number of votes in the State. The presidential electors of each congressional district shall cast their ballots for the presidential and vice-presidential candidates who received the largest number of votes in each respective congressional district;

NEB. REV. STAT. § 32-1038(1) (1994):

Receipt by the presidential electors of a party or a group of petitioners of the highest number of votes statewide shall constitute election of the two at-large presidential electors of that party or group of petitioners. Receipt by the presidential electors of a party or a group of petitioners of the highest number of votes in a congressional district shall constitute election of the congressional district presidential elector of that party or group of petitioners.

43. See McPherson v. Blacker. 146 U.S. 1 (1892) (holding that Michigan's use of congressional-district system, rather than winner-take-all system, was constitutional). For further discussion of McPherson, see infra Section III.A.

44. ALA. CODE § 17-19-2(a) (1995).

45. Id. § 17-19-2(b). 
candidates for the office of presidential elector equal in number to the state's electoral vote. ${ }^{46}$

In Alabama, as in many states, candidates for the office of presidential elector are required by law to sign a "pledge" promising to vote for the presidential candidate supported by their party ${ }^{47}$ In some states, the parties themselves extract pledges from the electoral candidates, while in other states, the electoral candidates are not pledged at all. Whether pledges are enforceable under state law is an open question..$^{48}$ It is likewise unclear whether Congress must count the vote of a "faithless" elector. From a constitutional standpoint, electors are free to vote for whomever they choose. ${ }^{49}$ Although Congress does have statutory authority to reject an electoral vote that is not "regularly given, ${ }^{, 50}$ it has never rejected a vote merely because it was cast for a candidate other than the one for whom the elector was expected to vote. ${ }^{51}$ As a practical matter, then, electors are bound primarily by their own consciences and their political loyalties.

46. Id. § 17-19-2(c).

47. See id. (requiring pledge); see also GLENNON, supra note 24, at 32 (reporting that 24 states and District of Columbia pledge their electors).

48. In Ray v. Blair, 343 U.S. 214 (1952), the Supreme Court held that Alabama's statute requiring electoral candidates to pledge their support for the party nominee did not violate the Constitution. The Court reserved judgment, however, as to whether such promises are "legally unenforceable because violative of an assumed constitutional freedom of the elector under the Constitution . . . to vote as he may choose in the electoral college." Id. at 230.

49. The Framers clearly contemplated that the electors would be prominent citizens who would exercise some independent judgment. See THE FEDERALIST No. 68, at 393 (Alexander Hamilton) (Isaac Kramnick ed., Penguin Books 1987) ("[T] ime immediate election should be made by men most capable of analyzing the qualities adapted to the station and acting under circumstances favorable to deliberation, and to a judicious combination of all the reasons and inducements which were proper to govern their choice."); ThE FEDERALIST No. 64, at 376 (John Jay) (Isaac Kramnick ed., Penguin Books 1987) (arguing that electors will be "the most enlightened and respectable citizens" and that their appointments will "bear at least equal marks of discretion and discernment").

As a practical matter, however, electors have almost never exercised this kind of independent judgment. Since they serve only a single, limited function, the only useful criterion for selecting one electoral candidate as opposed to another is the way in which that candidate plans to vote. Whatever authority makes the selection thus has a strong incentive to choose people who can reliably be expected to vote a particular way. In Ray v. Blair, Justice Jackson, in dissent, described the electors' function with an apt paraphrase from Gilbert and Sullivan's H.M.S. Pinafore:

They always voted at their Party's call

And never thought of thinking for themselves at all.

343 U.S. at 232 (Jackson, J., dissenting).

50. 3 U.S.C. $\$ 15$ (1988) (authorizing Congress to reject votes not "regularly given" by concurrent vote). The constitutional authority for this provision is unclear, although the Twelfth Amendment does specify that the President of the Senate shall count the electoral votes "in the presence of the Senate and House of Representatives." U.S. CONST. amend. XII.

51. It is unclear whether the vote of a faithless elector would be "regularly given" under the statute. In the past, Congress has only rejected votes for technical or procedural violations. such as votes cast on the wrong day or for candidates who had since died. GLENNON, supra note 24, at 36-37.

A significant dispute over this issue arose in the election of 1968, when Lloyd Bailey, an unpledged elector from North Carolina, voted for the third-party ticket of George Wallace and Curtis Lemay instead of the statewide winners, Richard Nixon and Spiro Agnew. See id. at 37-39. Although some members of Congress objected to the vote, neither the House nor the Senate sustained the objection. Id. 
In the Alabama general election, the names of the electoral candidates do not appear on the ballot. ${ }^{52}$ Instead, voters only see the name of the party and its candidates for President and Vice President. ${ }^{53}$ The statute provides that "[a] vote for a candidate for President or Vice-President shall be counted as a vote for the electors of the political party or independent body by which such candidates were named, as listed on the certificate of nomination or nominating petition." President is in fact a vote for a single, indivisible slate of presidential electors.

Once the state tallies the results of the popular election, the governor notifies the winning electoral candidates that they have been appointed to the office of presidential elector. ${ }^{55}$ On the date fixed by Congress-the first Monday after the second Wednesday in December-the electors meet at the state capital to vote for President and Vice President. ${ }^{56}$ In accordance with the Constitution, the votes are then transmitted to Washington to the President of the Senate. If for any reason, one or more electors fail to show up, the remainder must choose a substitute by plurality vote. ${ }^{57}$ Since presidential electors have overwhelmingly tended to cast their ballots for their party's nominees, ${ }^{58}$ as a practical matter, the presidential candidate who receives the most votes within a state will receive all of that state's electoral votes.

\section{Race, Presidential Politics, and the Winner-Take-All Rule}

The political realignment of the South is unquestionably the single most striking development in American presidential politics since 1948. Once a solid bloc of Democratic electoral votes, ${ }^{59}$ the South is now a more-or-less solid bloc of Republican electoral votes. Although the reasons for this shift are complex, it is beyond question that one of the principal forces driving it has been the violent opposition of white Southern politicians to the civil rights policies of the national Democratic party. ${ }^{60}$ This section argues that this shift is intimately bound up with the politics of the electoral college, and in

52. ALA. CODE \& 17-19-3 (1995).

53. Id.

54. Id.

55. Id. $\S 17-19-5$. If the two leading candidates receive the same number of votes, the governor is authorized to break the tie. Id. \$ 17-19-6.

56. 3 U.S.C. § 7 (1988) (fixing date of vote); ALA. CODE § 17-19-7 (1995) (instructing electors to vote on date authorized by Congress); see also U.S. CONST. art. II, $\$ 4$ (providing that day of choosing electors shall be uniform throughout United States).

57. ALA. CODE $\S 17-19-7$ (1995).

58. GLENNON, supra note 24 , at 32 (noting that more than $99 \%$ of electors have voted in accordance with pledges).

59. See CONGRESSIONAL QuARTERLY'S Guide to U.S. Elections 286-303 (2d ed. 1985).

60. Thomas Byme Edsall has identified several other factors that contributed to this shift, including taxation and redistribution of income; a "rights revolution" mandating federal protection of the rights of criminal defendants and other politically disempowered groups; and a procedural reform movement within the Democratic party. THOMAS B. EDSALL, CHAIN REACTION: THE IMPACT OF RACE, RightS, AND TAXES ON AMERICAN POLITICS 3-4 (2d ed. 1992). 
particular with the dominance of the winner-take-all system, which tends to ensure that the South will vote as a bloc. The national Republican party's efforts to control this bloc have forced it to move much farther to the right on issues of race, while the national Democratic party has scrambled to solidify its base of African-American voters. ${ }^{61}$ Modern presidential politics-not just in the South, but in the nation as a whole-can therefore only be understood in the context of this history. Accordingly, this section examines the ways in which Southern politicians have attempted to use their influence in the electoral college to exert control over national issues relating to race and civil rights.

\section{Strom Thurmond and the "Dixiecrat" Campaign of 1948}

The presidential campaign of 1948 marked the first in a series of efforts by white Southern politicians to manipulate the machinery of the electoral college to influence the national debate on civil rights. In that year, Southern Democrats in four states abandoned their party's nominee, President Harry S. Truman, and threw their support behind a segregationist ticket headed by $\mathrm{J}$. Strom Thurmond, the Democratic governor of South Carolina. ${ }^{62}$

Although "states' rights" was the rallying cry of the Southern Democrats-or "Dixiecrats," as they became known in common parlance-the true force that bound them together was their violent opposition to any measure of social and political equality for African-Americans. In 1948, the pressures that would ultimately crack the prevailing segregationist power structure of the South were just beginning to mount. Late in December 1947, the Fourth Circuit had upheld a federal court decision ordering the South Carolina Democratic party to allow blacks to vote in its primary. ${ }^{63}$ In February 1948, President Truman delivered a civil rights message to a joint session of Congress, calling for abolition of poll taxes, enactment of a federal anti-lynching law, creation of a permanent federal employment commission, and new measures to end discrimination in interstate transportation facilities. ${ }^{64}$ White Southerners were enraged. They responded with angry denunciations and threats to abandon the Democratic party, as well as with Ku Klux Klan rallies and cross burnings throughout the South. ${ }^{65}$

Southern politicians were determined to use their influence in the electoral college to defeat Truman's agenda. The intellectual blueprint for their strategy

61. See Edward G. Carmines \& Robert Huckfeldt, Party Politics in the Wake of the Voting Rights Act, in CONTROVERSIES IN MINORITY VOTING 117, 127-34 (Bernard Grofman \& Chandler Davidson eds., 1992).

62. For an account of Thurmond's 1948 presidential campaign, see NADINE COHODAS. STROM THURMOND AND THE POLITICS OF SOUTHERN CHANGE 126-93 (1993); PEIRCE \& LONGLEY, supra note 3. at 59-63.

63. See Rice v. Elmore, 165 F.2d 387 (4th Cir. 1947), cert. denied, 333 U.S. 875 (1948).

64. COHODAS, supra note 62, at 129.

65. Id. at 129-35. 
was an unabashedly racist political manifesto by Charles Wallace Collins, a Harvard-educated Alabama lawyer with an extensive background in federal government service, including stints as the law librarian of Congress and the librarian of the Supreme Court. ${ }^{66}$ His book, entitled Whither Solid South? A Study in Politics and Race Relations, portrayed the South as a region under legislative siege by a conspiracy of, among others, "the Negroes and the New York City radicals." ${ }^{167}$ With undeniable candor and considerable prescience, Collins wrote that:

These groups, with ever increasing pressure during the past ten years, are attempting to drive the South into a corner of moral isolation on the Negro race question, as a vantage point for hostile action. I have shown how these organizations ... are rallying to a new philosophy the slogan of which is the word "democracy" which in its very concept condemns in one breath the whole southern system, and how the whole movement is anchored to a craftily conceived legislative program to make the Negro equal to the white man economically, politically and socially. ${ }^{68}$

Collins proposed that white Southerners should combat these efforts by abandoning the Democratic party and allying themselves with conservative Republicans in the North and West. ${ }^{69}$ Failing that, he called on Southern Democrats simply to break away from the Northern Democrats and form their own political party. ${ }^{70}$

66. 32 WHO's WHO IN AMERICA 614 (1963). On the influence of Collins's book, see CoHODAs, supra note 62 , at 133 . Collins apparently remained an influential figure in segregationist political circles well into the next decade. Shortly after the Supreme Court's Brown decision, he offered quite cogent legal advice to Judge Leander Perez, the political boss of Plaquemines Parish in Louisiana, on the methods of circumventing school desegregation by abolishing public schools. GLEN JEANSONNE, LEANDER PEREZ: BOSS OF THE DELTA 230-31 (2d ed. 1995). Perez, a figure noted in Louisiana history for both his vicious racism and his remarkable career of political corruption, was apparently quite taken with Collins's books, and quoted from them during a televised debate with William F. Buckley in 1968 to prove that he was not a racist. Id. at 337,428 n.45. Buckley, unpersuaded, was left more-or-less speechless, although he did comment that Perez's ignorance was "'staggering." Id. at 337.

67. Collins, supra note 1 , at 258 . The following passage is typical of the flavor of Collins's book: In spite of the marked progress which they have made in the last twenty-five years, I do not see any chance for the Negro people ever to attain the full gratification of their desires in the American republic in the continental United States. There are now many happy Negroes in this country but they are on the southern plantations. They are ignorant, carefree and irresponsible-but happy. Last summer I saw on the streets of Los Angeles hundreds of these gay and happy-go-lucky Negroes fresh from the cotton fields of the Deep South. ... In San Francisco I was riding in a crowded streetcar packed with standing passengers. I had to worm my way through to get off. In my path was a little black pickaninny standing beside her jet black fat young mother. I said: "Look out, little sister, I am coming through." They both spontaneously looked me in the face and flashed a broad white-toothed smile as though happy to hear the sound of a voice from back home.

Id. at 303. Among other things, Collins also proposed establishment of a forty-ninth state in Africa where American blacks would be encouraged to live. Id. at 315-20.

68. Id. at vii.

69. Id. at 255-57.

70. Id. at 258. 
Manipulation of the electoral college was the crux of Collins's strategy. He noted that:

[T] here are two ... weapons of respectability available to the South which cannot be taken away from her without her consent-namely, her almost certain ability to prevent the Constitution from being amended and her power in the Electoral College. I have pointed out the logic of the conversion of the present Republican-Southern Democratic coalition into a new conservative political party. If that cannot be done it would be better for the South to fight independently in the Electoral College than to continue to keep political company with the left-wing New Dealers who are at heart the South's most bitter enemies. ${ }^{71}$

Collins proposed three distinct methods by which the South might tinker with the electoral machinery to block civil rights legislation. The first would be for Southern Democrats simply to nominate their own candidates for President and Vice President, along with slates of electors pledged to support them. By controlling a large bloc of electoral votes, a Southern Democratic party could force the election into the House of Representatives, and possibly control the outcome. ${ }^{72}$ Collins acknowledged that this plan had drawbacks. The principal one was that "the old Democratic Party in the North" might also try to run candidates in the South, and that "old loyalties" might prevail. ${ }^{73}$ To avoid this possibility, Collins proposed an alternative: abolition of the popular vote and direct appointment by the states of presidential electors pledged to support a Southern party nominee. ${ }^{74}$ As a third strategy, he suggested that Southern Democrats appoint electors who were not pledged to support the national party's nominee. ${ }^{75}$ The unpledged electors would then hold a convention after the popular vote in December and decide whom to support. ${ }^{76}$

The reaction of white Southern politicians to Truman's civil rights initiatives bears the unmistakable imprint of Collins's ideas. Four days after Truman's announcement, Southern governors met at Wakulla Springs, Florida, and denounced the President's efforts to end segregation. They adopted a resolution, written largely by Thurmond, which condemned efforts to undermine "the racial integrity and purity of the white and the negro races alike," and promised that white Southerners would not

71. Id. at ix.

72. Id. at $261-62$.

73. Id. at 262.

74. Id.

75. Id. at $262-63$.

76. Id. As we shall see, Southern politicians attempted a variant of this third strategy in 1960. See infra Subsection II.C.2. 
stand idle and let all of this happen, for the sole purpose of enticing an infinitesimal minority of organized pressure blocs to vote for one or another candidate for the Presidency. It is thought that we have no redress. This assumption ignores the electoral college set up in the Constitution of the United States. ${ }^{77}$

Determined to use their influence in the electoral college to deny Truman the Democratic nomination, party officials in Alabama, Mississippi, and South Carolina were soon in open rebellion. The Alabama Democrats adopted a new emblem for their state party: a rooster emblazoned with the words "White Supremacy" and "For the Right." Southern Democrats arrived at the national party convention in Philadelphia intending to keep any pro-civil rights language out of the party platform. When their efforts failed and a civil rights plank was included in the platform, half of the Alabama delegation and the entire Mississippi delegation walked out of the convention. ${ }^{79}$ At a rump convention in Birmingham, Southern Democrats nominated Thurmond as their candidate for President. The new nominee delivered a fiery acceptance speech, declaring, "'[T]here's not enough troops in the army to force the southern people to break down segregation and admit the Negro race into our theaters, into our swimming pools, into our homes, and into our churches."

Thurmond's aim was to force the election into the House, where Southern influence would either lead to his election as President or force the major parties to adopt conciliatory policies on civil rights. ${ }^{81}$ The dominance of the winner-take-all rule was crucial to this strategy. Rather than running Thurmond as a third-party candidate, the Dixiecrats sought to use the existing Democratic

77. CoHODAs, supra note 62 , at 133 (quoting text of resolution).

78. Id. at 139; see also PEIRCE \& LONGLEY, supra note 3, at 284-85 (reproducing 1960 presidential election ballot with rooster emblem on it, and noting that white supremacy slogan was discontinued in 1966).

79. COHODAS, supra note 62 , at 167 .

80. Id. at 177 (quoting Strom Thurmond, Acceptance of Presidential Candidacy at Southem Democratic convention (July 17, 1948)).

81. This strategy had an important historical antecedent. In 1876, much of the South was still under military control as part of Congress's Reconstruction program. In the presidential election that year, Democrat Samuel J. Tilden won a popular-vote victory over Republican Rutherford B. Hayes. The electoral vote results, however, were unclear-largely because of confusion and allegations of fraud in three Southern states. A special commission consisting of five Senators, five members of the House of Representatives and five Supreme Court Justices was set up to investigate the vote; it ultimately awarded all of the disputed electoral votes to Hayes, making him the apparent winner. In order for Hayes to be formally elected, however, Congress had to approve the count. With less than three days to go before the inauguration, Democrats in the House threatened to block approval. Ultimately, Hayes agreed to remove federal troops from the South and end Reconstruction in exchange for Democratic agreement to accept him as President. Shortly after the election, Hayes kept his part of the bargain-resulting in the near-total loss of all civil and political rights for Southern blacks. In 1948, a successful challenge by Thurmond could have perpetuated that result. Southem civil rights opponents were well aware of the outcome of the 1876 election, even if some of them were a bit hazy as to the details of what had actually taken place. See JEANSONNE, supra note 66, at 315-16.

On the election of 1876, see GLENNON, supra note 24, at 16-17; PEIRCE \& LONGLEY, supra note 3, at $52-57$. 
party machinery. Because of the Democrats' nearly total domination of state politics, its slate of electors was assured victory. Hence if the Democrats in a Southern state nominated a slate of electors pledged to Thurmond, rather than Truman, Thurmond would win that state.

By August, the Democratic party in four states-Alabama, Louisiana, Mississippi, and South Carolina-had nominated slates of presidential electors who were pledged to support Thurmond, rather than Truman. ${ }^{82}$ Truman did get on the ballot in three of those states, but was shut out in Alabama. ${ }^{83}$ In the general election, Thurmond won all four states, receiving a total of thirtynine electoral votes. Despite the Southern defection, however, Truman managed to eke out an unexpected win over his Republican opponent, Thomas E. Dewey.

Although these events may seem like ancient history, they are not. One example of how recent they are in our nation's political development is the fact that Thurmond, now a Republican and the senior Senator from South Carolina, is currently serving as President of the Senate pro tem ${ }^{84}$ - a position that, ironically enough, puts him fourth in line to succeed to the Presidency. ${ }^{85}$ The election of 1948 set the stage for a drama that was played out again in the South in the presidential elections of 1960 and 1968 and that, in many respects is still going on today.

\section{The Free Elector Movement of 1960}

By 1960, civil rights issues had erupted into the foreground of American politics. With Congress beginning to place antidiscrimination laws at the top of its agenda ${ }^{86}$ and the White House using federal troops to enforce the Supreme Court's integration decree ${ }^{87}$ the fears that Collins had expressed ten years earlier of a "Second Reconstruction" seemed to be coming true. ${ }^{88}$ And once again, Southerners attempted to use the electoral college to block it.

By 1958, white Southern politicians were laying the groundwork for what they described as a "free elector" plan-essentially a variant of the third

82. COHODAS, supra note 62 , at 181 .

83. Id. at 182 .

84. See S. Res. 4, 104th Cong., Ist Sess., 141 CoNG. REC. S418 (daily ed. Jan. 5, 1995) (enacted).

85. See 3 U.S.C. \$ 19 (1988).

86. Congress enacted a civil rights bill in 1957 despite vigorous opposition from Southern Democrats, including a record-length filibuster by Thurmond lasting 24 hours and 18 minutes. See COHODAS, supra note 62, at 294-300; see also TAYLOR BRANCH, PARTING THE WATERS: AMERICA IN THE KING YEARS $1954-63$, at 220-22 (1988).

87. In 1954, the Supreme Court had decided Brown v. Board of Education, 347 U.S. 483 (1954), holding that segregation in public schools was unconstitutional. Faced with widespread Southern resistance, President Eisenhower had ordered federal troops into Little Rock, Arkansas, in 1957 to carry out the Court's integration decree. See, e.g., BRANCH, supra note 86, at 222-25 (1988); see also Cooper v. Aaron, 358 U.S. 1 (1958) (upholding desegregation plan set out in Brown).

88. ColliNS, supra note 1 , at 262-63; see supra notes $72-76$ and accompanying text. 
scheme proposed by Collins. ${ }^{89}$ Rather than running their own candidate for President, however, proponents of this plan sought to change state law and party rules to allow the Democrats in Southern states to nominate a slate of presidential electors not pledged to support the national party nominee. ${ }^{90}$ Although support for the free-elector plan initially ran strong in several Southern states, ${ }^{91}$ the Democratic nominee, John F. Kennedy, managed to defuse the rebellion by selecting a Southerner, Senate Majority Leader Lyndon B. Johnson of Texas, as his running mate. ${ }^{92}$

Even with Johnson on the ticket, however, the unpledged-elector movement scored significant victories in two Southern states. In Alabama, Democratic voters chose the eleven members of the Democratic electoral slate in a primary election and a runoff. Only five of the winning candidates were pledged to support the national party's nominee; the remaining six were unpledged..$^{93}$ In Mississippi, Governor Ross Barnett, a leading backer of the free-elector plan and an ardent segregationist, succeeded in a move to have two slates of Democratic electors-one pledged to Kennedy and Johnson and one unpledged-placed on the ballot. ${ }^{94}$ All told, then, fourteen unpledged

89. See W.H. Lawrence, South Maps Move for 1960 Victory, N.Y. TIMES, June 5, 1958, at 26.

90. One of the leading backers of this plan in Louisiana was Judge Leander Perez, the political boss of Plaquemines Parish and a vicious opponent of integration. See JEANSONNE, supra note 66, at 313-22. As noted above, see discussion supra note 66 , Perez was quite familiar with Collins's work. This suggests that Collins's ideas had a direct influence on the 1960 unpledged-elector movement, as well as the subsequent campaign of George Wallace, in which Perez also played an important role. JEANSONNE, supra note 66 , at $315,344-45$.

91. By the spring of 1960 , the necessary changes had been adopted in Alabama, Arkansas, Georgia, Louisiana, Mississippi, and South Carolina. See Arthur Krock, Growth of 'Free Elector' Movement in South, N.Y. TIMEs, Mar. 4, 1960, at 24; Claude Sitton, Dixiecrat Move Gains Adherents, N.Y. TimEs, Mar. 22, 1959, at 1; see also Act of Mar. 21, 1958, \$ 6, $1958 \mathrm{Ga}$. Laws 208, 211 (amending prior law to provide that names of candidates for elector and their party be placed on ballot, but that name of presidential candidate be omitted).

92. See Most Southern Governors Cool to Suggestion They Bolt Ticket, N.Y. TIMES, July 20, 1960, at 16 (reporting view of Georgia governor that choice of Johnson strengthened ticket in Georgia, as well as increasing support for ticket from governors of Kentucky, Alabama, and Tennessee); see also PEIRCE \& LONGLEY, supra note 3, at 64 ("Johnson's presence on the ticket was probably an essential element in holding most of the South behind Kennedy and effecting Democratic victory in one of the closest elections of U.S. history.").

Had Kennedy chosen the more liberal Senator Hubert H. Humphrey of Minnesota, a strong supporter of civil rights, Southern states would certainly have been more inclined to bolt the party, as they had in 1948. See Arthur Krock, Darkening Party Prospect for the South, N.Y. TIMES, June 28, 1960, at 30 (reporting "consternation" among Southern Democrats at prospect that Humphrey might be vice-presidential nominee).

93. PEIRCE \& LONGLEY, supra note 3, at 66.

94. Claude Sitton, Democrats to Offer 2 Mississippi Slates, N.Y. TIMES, Aug. 17, 1960, at 1.

In other Southern states, party loyalty prevailed over antipathy toward civil rights. In Georgia, voters approved a referendum releasing electors from their pledges. Claude Sitton, Georgia Electors 'Freed' By Voters, N.Y. TIMES, Sept. 16, 1960, at 22 . The referendum was essentially an empty formality, however, since it was nonbinding, and most electors on the Democratic slate had already expressed their loyalty to Kennedy and Johnson. Id: see also Vandiver Backs His Party Slate. N.Y. TIMES. Aug, 23, 1960, at 20. In South Carolina, Governor Emest F. Hollings, a Kennedy backer, initially supported the idea of having both a pledged and an unpledged-elector slate on the ballot, as in Mississippi, but subsequently reversed his position. Claude Sitton, South Carolina in Kennedy Shift, N.Y. TIMES, Aug. 15. 1960, at 14 (noting that Hollings endorsed Kennedy but submitted resolution providing for unpledged-elector slate to state party 
Democratic electors were elected from the South: six from Alabama, and eight from Mississippi, where the unpledged slate defeated the Kennedy-Johnson slate. $^{95}$

Efforts to manipulate the electoral system to block civil rights initiatives did not cease after the popular vote, however. Although Kennedy appeared to have defeated Nixon in the popular vote and to have gained a slight electoral vote majority, allegations of fraud and widespread irregularities at the polls meant that the results were far from certain. If Kennedy had lost Illinois, he would have had only 273 electoral votes-only four more than he needed to win the election. In that scenario, if the unpledged electors could have persuaded at least four other electors to join them, they could have denied Kennedy the White House, or more likely, could have wrested concessions from him on civil rights. ${ }^{96}$ Shortly after the election, an Alabama lawyer called for all of the Southern electors to meet with Kennedy to point out the " vital importance of Southern electoral votes in his attaining the Presidency." ${ }^{\prime 97}$ Alabama newspapers backed the idea of an electoral revolt on openly segregationist grounds, condemning "[f]ederal efforts to force racial mixing in New Orleans" and the "enslavement" of Southern children as a result of school integration efforts. ${ }^{98}$ Mississippi Governor Barnett sent out letters to electors in six other states asking them not to vote for Kennedy. ${ }^{99}$ In Louisiana, leaders of the White Citizens Council sought to have the state's electors withhold votes from Kennedy, stating that he had "gone wild on integration." 100

Ultimately, the fourteen unpledged electors decided to cast their votes for Senator Harry F. Byrd of Virginia, ${ }^{101}$ the man who four years earlier had pledged "massive resistance" to the Supreme Court's school desegregation

convention); Claude Sitton, South Carolina Assists Kennedy, N.Y. TimEs, Aug. 16, 1960, at 18 (observing Hollings's reversal and plea for party unity and convention's defeat of resolution). State party officials rejected a move to place unpledged electors on the ballot-but made it clear that Democrats unsatisfied with the ticket were free to support the Republican ticket of Richard Nixon and Henry Cabot Lodge. Id. In Louisiana, a sharply divided Democratic State Central Committee voted 51-49 to pledge its electors to Kennedy and Johnson. Claude Sitton, Democrats Block Bolt in Louisiana, N.Y. TIMES, Aug. 12, 1960, at 1.

95. See PEIRCE \& LONGLEY, supra note 3, at 65-66, 69; see also Claude Sitton, Kennedy Scores Heavily in South, N.Y. TIMES, Nov. 9, 1960, at 1 ("Mississippi voters wandered off into an uncharted political wasteland behind a slate of independent Democratic electors. Those pledged to Mr. Kennedy ran second and the Republicans a poor third.").

96. See Mississippi Vote Held for $3 d$ Man, N.Y. TIMES, Nov. 12, 1960, at 11; see also PEIRCE \& LONGLEY, supra note 3, at 69.

97. Elector Parley Urged, N.Y. TimEs, Nov. 13, 1960. at 86 (quoting Montgomery attomey Lea Harris).

98. 2 Alabama Papers Ask Kennedy Upset, N.Y. TIMES, Nov. 19, 1960, at 13.

99. See Kennedy Bolt Urged, N.Y. TimES, Nov. 30, 1960, at 31; see also PEIRCE \& LONGLEY, supra note 3 , at 69 .

100. Louisianan Continues Fight, N.Y. TIMES, Dec. 6, 1960, at 30; see also PEIRCE \& LONGLEY, supra note 3, at 69; Louisiana Shift Blocked, N.Y. TIMES, Nov. 29, 1960, at 25.

101. PEIRCE \& LONGLEY, supra note 3, at 69. 
decisions. ${ }^{102}$ Resistance to civil rights reforms was the guiding principle behind their choice. Calling on electors from other states to join them, the unpledged electors declared that Byrd's election would depend "upon whether or not the people of the South who have expressed their dedication to the principles of constitutional government and to the right of a state to determine for itself the questions of segregation and freedom of association are sincere in the continued expressions of such dedication." ${ }^{103}$ In announcing their decision not to vote for Kennedy, Alabama electors called for "the preservation of racial and national integrity" and voiced vehement opposition to efforts to

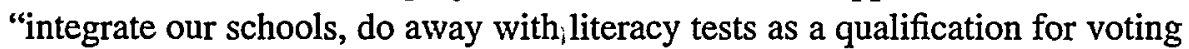
[and] otherwise undermine everything we hold dear in the South." 104

The free-elector movement of 1960 thus represents another deliberate effort by Southern segregationists to use the electoral system to change the course of the national debate over race and civil rights. Ultimately, of course, Byrd received only fifteen electoral votes. ${ }^{105}$ Kennedy won the election, with 303 electoral votes to Nixon's 219. Thus, the segregationist electors were not able to alter the outcome of the election as they had hoped. However, they were able to demonstrate the central importance of racial issues in controlling the Southern vote in the electoral college-a lesson that Nixon would take to heart eight years later in his next bid for the presidency.

\section{The Wallace Campaign of 1968 and the Rise of the Republican South}

Overt racist appeals and efforts to manipulate the electoral system materialized again in the election of 1968. That election saw yet another attempt by an openly segregationist third-party challenger to manipulate the electoral system. This time the challenger was Alabama Governor George C. Wallace, who had become notorious for his no-holds-barred stance against integration when, in his 1963 inaugural address, he proclaimed that, "In the name of the greatest people that have ever trod this earth, I draw the line in the dust and toss the gauntlet before the feet of tyranny ... and I say ... segregation now ... segregation tomorrow ... segregation forever."'106

102. J. HaRvie Wilkinson III, HaRry Byrd and the Changing Face of Virginia Politics, $1945-1966$, at 113 (1968).

103. 14 Electors Vow to Vote for Byrd, N.Y. TIMES, Dec. 13, 1960, at 23.

104. Six Electors Bar Kennedy Support, N.Y. TIMES, Dec. 11, 1960, at 56.

105. The 14 Democratic Byrd electors were joined by one Republican, an Oklahoma man from a winning slate pledged to Nixon and Lodge. Shortly after the popular vote, the Oklahoma elector, Henry Irwin, had telegraphed other Republican electors and suggested that they join forces with Southern Democrats and support Byrd for President. PEIRCE \& LONGLEY, supra note 3, at 70.

106. Dan T. Carter, THE Politics of Rage: George Wallace. THE ORIgins of the NeW CONSERVATISM, AND THE TRANSFORMATION OF AMERICAN POLITICS 11 (1995) (ellipses indicate purposeful pauses in address); see also id. at 9-10,109. Wallace's notoriety grew when, in a carefully arranged media event, he defied President Kennedy's orders and physically blocked Assistant Attorney General Nicholas Katzenbach from entering a campus building at the University of Alabama to register black students. See, e.g., BRANCH, supra note 86, at 821-22 (noting that Alabama governor's "contemptuous nationwide 
Furthermore, the 1968 election marked the beginning of the modern period of Republican domination of the South, as an increasing number of one-time Dixiecrats began to shift their allegiance to Nixon and the GOP. ${ }^{107}$

In many respects, Wallace's campaign was similar to Thurmond's campaign in 1948. Blatant racism and continued support for segregation were integral to the message delivered by both men. ${ }^{108}$ There was one key difference, however. Wallace, unlike Thurmond, was determined to wage a nationwide campaign. His supporters were highly organized, and they managed to get his name placed on the ballot in all fifty states-a logistical feat that many had thought impossible for a third-party candidate. ${ }^{109}$ Wallace was aided in this effort by the fact that, by 1968 , race was no longer simply a Southern issue. Beginning with the 1965 Watts riots in Los Angeles, a series of violent disturbances in urban black neighborhoods had forced race to the forefront of the nation's political consciousness. ${ }^{110}$ In 1968, the assassination of Martin Luther King touched off a wave of riots in more than 100 cities throughout the nation, resulting in thirty-nine deaths and almost 20,000 arrests. ${ }^{111}$ This tide of violence prompted both Wallace and the Republican candidate, Richard Nixon, to make "law and order" a prominent theme of the presidential campaign - a theme that in Wallace's rhetoric had none-too-subtle racial overtones. ${ }^{112}$ School desegregation efforts, once limited to the South, were gathering strength in other areas, offering Wallace and Nixon another campaign theme. ${ }^{113}$

address ... helped elevate Wallace from the marginal stature of a Ross Barnett into a presidential contender"); CARTER, supra, at 142-53. Wallace's standing in racist political circles increased even further with the brutal crackdowns by Alabama authorities on civil rights protesters in Birmingham in 1964, see id. at 114-17, 124-28, and Selma in 1965, see id. at 246-50.

107. The beginnings of the Southern shift to the Republican party can actually be traced back to the election of 1964, in which Republican Barry Goldwater carried five Southern states-Alabama, Georgia, Louisiana, Mississippi, and South Carolina-as well as his home state of Arizona. See EDSALL, supra note 60 , at 7,32-46. Goldwater's popularity in the South was primarily due to his opposition to the Civil Rights Act of 1964 and other federal efforts to end segregation. Id. at 38-41. Nixon, however, unlike Goldwater, was able to integrate his Southem strategy into a successful national campaign.

108. See, e.g., CARTER, supra note 106, at photo insert (reproducing flyer used by Wallace in 1970 gubernatorial campaign, containing photograph depicting white girl surrounded by African-American children, with caption reading, "This Could Be Alabama Four Years From Now! Do You Want It?").

109. Peirce \& LONGLeY, supra note 3, at 73-74; TheOdoRe H. White, THE MAKING of THE PRESIDENT, 1968, at 346-47 (1969); see also Williams v. Rhodes, 393 U.S. 23, 26 (1968).

110. See CARTER, supra note 106, at 301-08; WhITE, supra note 109, at 23-29, 199-206.

111. WHITE, supra note 109, at 207-09.

112. See CARTER, supra note 106 , at $347-49$. With respect to Nixon's stance on the law-and-order issue, Carter notes one occasion on which the candidate's carefully planned race-neutral facade slipped, and he told his staff that a television commercial was "all about law and order and the damn Negro-Puerto Rican groups out there."' Id. at 348.

113. Id. at 349-50. Theodore $\mathrm{H}$. White quotes an interview in which Wallace proclaimed:

"By the fall of 1968, the people of Cleveland and Chicago and Gary and St. Louis will be so god-damned sick and tired of Federal interference in their local schools, they'll be ready to vote for Wallace by the thousands. The people don't like this triflin' with their children, tellin' 'em which teachers to have to teach in which schools, and bussing little boys and girls half across a city just to achieve "the proper racial mix."

WHITE, supra note 109 , at 346. 
Wallace's strategy was also similar to that of his Dixiecrat predecessorbut with one important twist. As he revealed in an interview after the election, he never had any intention of letting the election go into the House, where he would not have controlled a single state delegation. If he had collected enough electoral votes to block either of the two major party nominees-Hubert Humphrey for the Democrats, or Richard Nixon for the Republicans-from getting an electoral college majority, Wallace would have attempted to strike a bargain with Nixon, throwing the support of Wallace's electors to the Republican in exchange for concessions on civil rights. ${ }^{114}$

The 1968 election also solidified Republican domination of the "Solid South." Prodded by Thurmond, who had become a Republican in 1964, ${ }^{115}$ the GOP began to bid heavily for the support of the Dixiecrats. ${ }^{116}$ In the presidential election, Thurmond and other one-time Democrats threw their support behind Nixon. ${ }^{117}$ The "Southern strategy" paid off, not just for Nixon in 1968, but for the Republican party. By appealing to the white segregationist bloc that had controlled Southern politics since the end of Reconstruction, Nixon captured six Southern states: Florida, Kentucky, North Carolina, South Carolina, Tennessee, and Virginia. Wallace won another five states: Alabama, Arkansas, Georgia, Louisiana, and Mississippi. Once again, the winner-take-all system ensured that African-American voters, unlikely to support either Wallace or the Thurmond-backed Nixon, could not choose a single elector in these eleven states.

\section{Racial Politics and Present-Day Campaigns}

In the four most recent presidential elections, the South has been solidly in the Republican camp, notwithstanding a dramatic surge in the number of African-Americans registered to vote. ${ }^{118}$ But as the gradual realignment of white Southerners from 1948 to 1968 makes clear, the current Republican domination of the electoral college in the South is no accident. Rather, it is in large part the result of a conscious effort by white Southern politicians-first by segregationist Democrats, and later by racially conservative Republicansto make race a focal point of presidential politics. ${ }^{119}$

114. PEIRCE \& LONGLEY, supra note 3, at 75.

115. COHODAS, supra note 62 , at 318 .

116. See id. at 385 (describing racial appeals by Republican party and pro-Thurmond "Independents" in Thurmond's 1966 Senate campaign).

117. See id. at 396-400: WHITE, supra note 109, at 137-38.

118. See BERNARD GROFMAN ET AL., MINORITY REPRESENTATION AND THE QUEST FOR VOTING EQUALITY 21-23 (1992) (describing surge in black political participation in South in wake of 1965 Voting Rights Act and its 1970 and 1975 extensions).

119. See Carmines \& Huckfeldt, supra note 61, at 120-25 (arguing that, while racial positions of national Democratic and Republican parties were similar in 1960, parties and public perceptions of party positions diverged starkly along racial lines after 1964). 
Today, race remains a polarizing force in presidential politics. ${ }^{120}$ The realignment of the bloc of white racial conservatives from the Democratic party to the Republican party has altered the political picture, however. Because of this shift, racial conservatives no longer need to manipulate the electoral college in the manner that Thurmond and Wallace attempted. Instead, they rely on the discriminatory mathematics of the winner-take-all system, which ensures that racial minorities have no voice in determining the composition of the electoral college. Republicans today often refer to their party as having a "lock" on the electoral college by virtue of its dominance in the South. ${ }^{121}$ Such terminology echoes-though perhaps unconsciously-the language used by Collins nearly fifty years ago.

Racial appeals continue to be a staple of presidential politics. Rather than relying on overt racist imagery, as Thurmond did in 1948, modern politicians generally play the "race card" through subtle use of code words and careful manipulation of racial imagery. ${ }^{122}$ For example, George Bush's victory over Michael Dukakis in 1988 is frequently attributed to his campaign's skillful handling of racial imagery-most notably the infamous "Willie Horton" episode.$^{123}$ Indeed, many of the rhetorical devices and subtle racial images employed by modern-day Republicans are essentially variations on themes developed by Wallace in his 1968 campaign. ${ }^{.24}$ Issues of race are frequently closely tied to a number of "social issues," ranging from crime to welfare to affirmative action. ${ }^{125}$

120. For a thorough account of the fundamental role race plays in modem presidential politics, see EDSALL, supra note 60 .

121. See, e.g., E.J. Dionne Jr., Analyzing the Electoral Vote: Does G.O.P. Have a 'Lock'?, N.Y. TIMES, Oct. 12, 1988, at A1.

122. See, e.g., EDSALL, supra note 60, at 203-06, 213-14, 221-27.

123. Horton was a convicted murderer who had been released from a Massachusetts prison for a weekend furlough during Dukakis's tenure as governor. While free, he fled the state and committed a violent rape. See, e.g., JACK W. GERMOND \& JULES WITCOVER, WHOSE BROAD STRIPES AND BRIGHT Stars? The Trivial Pursuit of the PREsidenCy, 1988, at 10-12 (1989). This incident subsequently became the subject of a nationally broadcast Bush campaign commercial. Although the commercial did not show a picture of Horton, it was well known that he was African-American, and his picture was prominently displayed on flyers distributed by a state committee and in at least one television commercial put out by an independent group. Bush also made frequent references to the Horton incident in campaign appearances and speeches. Id. at $11,357-58,411,422-23$.

124. See EDSALL, supra note 60, at 10-11; see also CARTER, supra note 106, at 466-68. Carter ends his analysis of Wallace's contribution to American political discourse with the pithy observation that the Alabama governor is "the most influential loser in twentieth-century American politics." Id. at 468.

It is worth noting that even some of Thurmond's 1948 rhetoric survives to this day. A prominent element of the Republican party's agenda in the 1994 campaign was support for "states' rights"-a term that, from 1948 on, has been closely associated with supporters of segregation. I do not mean to suggest that supporters of states' rights are necessarily racists-merely that the term has quite distinct racial overtones.

125. Early in the 1996 presidential race, several Republican candidates said that ending affirmative action was one of their primary goals. See, e.g., Richard L. Berke, Politicians Start Yearlong Siege of New Hampshire, N.Y. TIMES, Feb. 20, 1995, at A1 (noting Senator Robert Dole's, Senator Phil Gramm's, and former Governor Lamar Alexander's statements that ending affirmative action is at top of their list of goals). 
Race surfaces in other unexpected ways in our national politics. In the current presidential campaign, many members of the media enthusiastically touted General Colin Powell, a prominent African-American and the former chairman of the Joint Chiefs of Staff, as a possible Republican candidate for President. In many ways, this phenomenon was curious, because Powell had never sought public office or offered any hint of a political agenda. While the origins of the Powell noncandidacy are complex, it seems undeniable that one of the primary reasons for the media fascination with him was his race. As an African-American Republican (or at least, a presumed Republican), Powell did not fit into established categories. He was seen as someone who might be able to attract the support of both black Democrats and white Republicans. In this respect, Powell's backers were tacitly acknowledging the stranglehold that race has on the American electorate. Indeed, Powell acknowledged as much in his speech announcing that he would not run for President, commenting that he wanted "'to help the party of Lincoln move, once again, close to the spirit of Lincoln.""126

Racial politics also play an important role on the other side of the political aisle. Democratic candidates frequently try to walk an almost impossibly fine line, desperately trying to distance themselves from black political interests without alienating their African-American political base. ${ }^{127}$

In short, race has by no means been a trivial or incidental issue in presidential politics of the modern era. Far from it, race has been a central issue in the most important political trend of the last fifty years: the conversion of the South from a Democratic bastion to a Republican one, and the

126. Excerpts from General Powell's News Conference on Political Plans, N.Y. TIMES, Nov. 9, 1995, at B13. In response to a question, Powell amplified this comment by stating that:

[A] very large percentage of blacks don't believe the Republican party appeals to them and they vote consistently Democratic. And I think it would be in the interest of minorities, and especially for African-Americans, to have other choices. And I think it would be an important Id. thing for the Republican party to broaden its appeal.

In an earlier interview, Powell's wife made a comment that further highlights the central importance of race in presidential politics. In response to the question, "Do you fear for your husband's safety should he run?" Alma Powell responded: "'Yes, he would probably be at much more risk than any other candidate because of the-of being a black man in this society. There's a lot of crazy people out there." 20/20 (ABC television broadcast, Sept. 15, 1995), available in LEXIS, News Library, ABCNews File. The suggestion that an African-American running for President in the United States in 1995 would face special perils is disturbing, and should not be lightly discounted. Indeed, threats and violence directed at potential AfricanAmerican candidates have historically been two of the principal methods by which Southerners deprived minorities of political power. See Chandler Davidson, Minority Vote Dilution: An Overview, in MINORITY VOTE DILUTION 1, 3-4 (Chandler Davidson ed., 1984) (discussing problem of candidate discouragement).

127. An interesting example of this phenomenon occurred in 1992, when Democratic candidate Bill Clinton made a point of publicly criticizing remarks made by a black rap singer, Sister Souljah, at a meeting of Jesse Jackson's Rainbow Coalition shortly before the Democratic convention. The remarks were widely viewed as part of a Clinton strategy to keep from being too closely identified with Jackson, and with black interests, in the minds of white voters. See, e.g., R.W. Apple Jr., Jackson Sees a 'Character Flaw' in Clinton's Remarks on Racism, N.Y. TIMES, June 19, 1992, at Al (describing Clinton's remarks as "part of an effort to suggest that unlike the Democratic nominees who have lost five of the last six Presidential elections, he could stand up to minorities and interest groups"). 
Republican party's corresponding shift from a moderate stance on racial policies to a much more extreme position. ${ }^{128}$ In effect, the battle between the parties for control of the South has led to their severe divergence with respect to racial issues-a change that has been felt not just in the South, but nationwide.

For nearly five decades, politicians have been relying on the primacy of the winner-take-all scheme as a means of excluding African-American voters from the political process. The efforts of Strom Thurmond and George Wallace to inject race into the presidential contests in 1948 and 1968 help to illustrate the logic of George Bush's attempts to do much the same thing in 1988. This recurring emphasis on race all but guarantees the continued occurrence of racially polarized voting, and consequently ensures that minority voters will not enjoy an equal opportunity to participate in the selection of their Chief Executive.

\section{APPLICATION OF THE Voting RIGHTS ACt to THE ELECTORAL SYSTEM}

Section 2 of the Voting Rights Act of 1965, as amended by Congress in 1982 , is one of the most powerful and far-reaching civil rights statutes enacted in our nation's history. In its current form, the statute reads as follows:

(a) No voting qualification or prerequisite to voting or standard, practice, or procedure shall be imposed or applied by any State or political subdivision in a manner which results in a denial or abridgement of the right of any citizen of the United States to vote on account of race or color ... as provided in subsection (b) of this section.

(b) A violation of subsection (a) of this section is established if, based on the totality of the circumstances, it is shown that the political processes leading to nomination or election in the State or political subdivision are not equally open to participation by members of a class of citizens protected by subsection (a) of this section in that its members have less opportunity than other members of the electorate to participate in the political process and to elect representatives of their choice. The extent to which members of a protected class have been elected to office in the State or political subdivision is one circumstance which may be considered: Provided, That nothing in this section establishes a right to have members of a protected class elected in numbers equal to their proportion in the population. ${ }^{\text {i29 }}$

128. See Carmines \& Huckfeldt, supra note 61 , at 121-25.

129. 42 U.S.C. $\$ 1973$ (1988). The language I have omitted from subsection (a) stems from the 1975 amendments to the Act, which extended its protection to language minorities, such as Hispanics. as well as to racial groups like African-Americans. See id. §1973b(f)(2). 
Congress designed this statute, with its heavy emphasis on results, to put an end to the use of a category of discriminatory practices known as vote dilution. Vote dilution occurs when an electoral scheme functions in such a way as to limit the ability of members of a minority group to influence the political process as a practical matter. Thus, even a scheme that appears to be fair from a purely formal standpoint may violate $\S 2$ if it tends to minimize minority voting power in its operation.

For instance, consider a hypothetical town of 1000 voters, 700 of whom are white and 300 of whom are black. Suppose that this town is governed by a ten-member city council elected at large by majority vote. In any election, each voter is entitled to vote for one candidate for each of the city council seats to be filled. If the council terms are not staggered, each voter will thus be able to cast one ballot for each of ten different candidates in the typical election. At-large electoral schemes of this type were once quite common in this country, and still exist in many places. ${ }^{130}$ Municipal reformers at the turn of the century argued that at-large systems would produce better governments by forcing candidates to run for office citywide rather than trying to appeal to one particular faction. ${ }^{131}$ One problem with this argument is that voting is often polarized along racial lines. ${ }^{132}$ Suppose that the 700 white voters, or at least a significant portion of them, tend to vote as a bloc. Under an at-large electoral scheme, they will be able to pick all ten council members. AfricanAmerican voters may have very different preferences, but no matter how strongly cohesive they are, they will never be able to elect any candidate other than one supported by the white majority. They can vote, but they do not have a real influence on the outcome of the election.

Congress enacted the 1982 amendments to $\S 2$ in response to a 1980 Supreme Court decision dealing with just this type of discrimination. In City of Mobile v. Bolden, ${ }^{133}$ the Court had held that neither the Fourteenth nor the Fifteenth Amendment barred the use of a dilutive at-large system absent a showing that it was adopted or maintained for a discriminatory purpose. ${ }^{134}$

130. See Richard L. Engstrom \& Michael D. McDonald, The Effect of At-Large Versus District Elections on Racial Representation in U.S. Municipalities, in EleCtORAL LAWS AND THEIR POLITICAL CONSEQUENCES 203, 204-05 (Bernard Grofman \& Arend Lijphart eds., 1986); see also Holder v. Hall, 114 S. Ct. 2581, 2594-95 (1994) (Thomas, J., concurring in judgment) (noting that multimember districts were once "a common feature of our political systems" and "continue to be a feature on the American political landscape").

131. Engstrom \& McDonald, supra note 130, at 203-04.

132. Many of the "reformers" who backed at-large government were quite aware of this drawback. At-large election systems were seen as a way to keep recently arrived immigrant groups in the North and African-Americans in the South from gaining political power. See Chandler Davidson \& Bernard Grofman, Editors' Introduction to QUIET REVOLUTION, supra note 2, at 3, 7.

133. 446 U.S. 55 (1980).

134. The Court later backtracked from this position in Rogers v. Lodge, 458 U.S. 613, 620-22 (1982). holding that the showing of intent could be evidenced indirectly through the type of evidence considered in White v. Regester, 412 U.S. 755 (1973) and Zimmer v. McKeithen, 485 F.2d 1297 (5th Cir. 1973), aff'd on other grounds sub nom. East Carroll Parish School Board v. Marshall, 424 U.S. 636 (1976) (per curiam). 
Congress responded by adding $\S 2(b)$ and the "results" language of $\S 2$ (a), creating a generally applicable statutory basis for vote-dilution claims. ${ }^{135}$ Four years later, in Thornburg v. Gingles, ${ }^{136}$ the Court held that the amended $\S 2$ incorporated a results test, and invalidated a multimember system of election to the North Carolina state legislature. In the wake of Gingles, courts have routinely used $\S 2$ to strike down at-large systems and multimember districts where plaintiffs have been able to show sufficient levels of racially polarized voting. ${ }^{137}$ In recent years, courts have held the statute applicable against single-member districts as well, ruling that it prohibits jurisdictions from drawing plans that are intentionally or inadvertently gerrymandered in a manner that unduly limits the ability of minority voters to elect candidates of their choice. ${ }^{138}$

Thus far, no court has faced a claim applying $\S 2$ to the winner-take-all system of choosing presidential electors. Certain functional similarities between the winner-take-all system and the type of electoral scheme addressed in Gingles are readily apparent, however. In both types of scheme, candidates run for office at large. As a consequence, a cohesive voting majority can pick all of the winning candidates, leaving the minority with no voice at all in the system. Whether this will actually happen, of course, depends on the precise

135. See S. REP. No. 417 , 97th Cong., 2d Sess. 15 (1982) ("The proposed amendment to Section 2 of the Voting Rights Act is designed to restore the legal standard that govemed voting discrimination cases prior to the Supreme Court's decision in Bolden.").

Prior to the 1982 amendment, the primary statutory basis for vote-dilution claims was $\$ 5$ of the "Voting Rights Act, 42 U.S.C. $\$ 1973 \mathrm{c}$ (1988). Section 5 bars certain "covered" jurisdictions from enforcing any change in their electoral laws without first obtaining "preclearance" from the U.S. Justice Department or a declaratory judgment from the U.S. District Court for the District of Columbia stating that the proposed change was not enacted for a discriminatory purpose and will not have a discriminatory effect. In Allen v. State Board of Elections, 393 U.S. 544 (1969), the Supreme Court interpreted this provision broadly to apply to any change in an electoral scheme. It explicitly held that a covered jurisdiction could not change its form of government from a single-member-district scheme to an at-large one without getting either judicial or administrative preclearance. $I d$. at 569 . The Court noted that

[v]oters who are members of a racial minority might well be in the majority in one district, but in a decided minority in the county as a whole. This type of change could therefore nullify their ability to elect the candidate of their choice just as would prohibiting some of them from voting.

Id. Section 5, though a powerful weapon, is also a limited one. It applies only to changes in electoral systems. Jurisdictions that had at-large systems prior to the effective dates of the Voting Rights Act are not affected. Furthermore, $\$ 5$ applies only to "covered" jurisdictions-principally, but not exclusively, the Southern states. By contrast, $\$ 2$ applies to all states and political subdivisions.

136. 478 U.S. 30 (1986).

137. See, e.g., Meek v. Metropolitan Dade County, 985 F.2d 1471 (11th Cir. 1993); Westwego Citizens for Better Gov't v. City of Westwego, 946 F.2d 1109 (5th Cir. 1991); Campos v. City of Baytown, 840 F.2d 1240 (5th Cir. 1988), cert. denied, 492 U.S. 905 (1989); Citizens for a Better Gretna v. City of Gretna, 834 F.2d 496 (5th Cir. 1987), cert. denied, 492 U.S. 905 (1988); Brown v. Board of Comm'rs, 722 F. Supp. 380 (E.D. Tenn. 1989).

138. See, e.g., Johnson v. De Grandy, 114 S. Ct. 2647, 2655-63 (1994) (applying Gingles analysis to single-member-district scheme but finding no $\$ 2$ violation because scheme achieved rough proportionality).

Recent Supreme Court decisions may sharply curtail the applicability of $\$ 2$ to single-member-district schemes. See, e.g., Miller v. Johnson, I15 S. Ct. 2475 (1995) (holding that redistricting plan violated Constitution because drawn predominantly to benefit minorities and lacked compelling state interest). Thus far, however, these decisions do not appear to alter the Court's basic analytical framework with respect to at-large plans. 
dynamics of the community: the racial preferences of its voters, the strength of particular candidates, the importance of the office being sought, and so forth. In one important respect, however, the winner-take-all system is potentially much more discriminatory. In the typical at-large system, voters have the freedom to split their vote among candidates from different parties. For example, in an at-large city council election, a loyal Democrat might be willing to support one or two strong Republican candidates, even if she favored the Democratic slate overall. ${ }^{139}$ Under a winner-take-all rule, voters do not have the option to split their vote. They must vote for one slate or another as a unit. Consequently, if a sufficiently strong correlation exists between race and voter preference, a racial minority will automatically be denied the opportunity to choose even a single representative.

A question thus naturally arises: Does $\S 2$ apply to a state's decision to employ the winner-take-all system for choosing electors rather than one of the alternative methods? This inquiry may be broken into two parts, one a question of constitutional law and the other a question of statutory interpretation. First, does Congress have any constitutional power to regulate the appointment of electors? And second, if Congress does have authority to regulate the electoral process, has it actually exercised that power in $\S 2$ ? Section A addresses the first of these questions, and Section B addresses the second.

\section{A. Constitutional Authority}

At the outset, it seems clear that nothing in the original Constitution gave Congress any power to regulate the manner in which states appoint presidential electors. As noted above, Article II appears to grant state legislatures exclusive power over the appointment of electors. ${ }^{140}$ Comparing Article II with Article I, which governs the selection of Members of Congress, suggests that the absence of congressional authority in Article $\Pi$ was no mere oversight on the part of the Framers. Article I specifies how Representatives are to be apportioned among the states, but does not specify a manner of election. ${ }^{141}$ Instead, it leaves it in the first instance to the state legislatures to determine the "Times, Places and Manner of holding Elections for Senators and Representatives." 142 Hence, under the original constitutional framework, states were free to adopt a winner-take-all or other at-large scheme for choosing House Members. In fact, several states did use the general-ticket

139. Such "ticket splitting" is an increasingly important feature of American politics. See MARTIN P. Wattenberg, The Decline of American Political Parties 1952-1992, at 17-23, 162-66, 177-78, 189-93 (1994); Amar \& Amar, supra note 40, at 914-16.

140. See U.S. CONST. art. II, \& 1, cl. 2 ("Each State shall appoint, in such Manner as the Legislature thereof may direct, a Number of Electors .....").

141. Unlike presidential electors, however, Representatives must be chosen "by the People," and thus may not be appointed by the state legislatures. Id. art. I, § 2, cl. 1 .

142. Id. art. I, \$ 4, cl. 1 . 
system for electing Representatives prior to $1842 .{ }^{143}$ Article I, however, gives Congress a power with respect to the election of Representatives that Article II does not grant with respect to presidential electors; it specifically states that Congress may override state decisions concerning the times, places, and manner of congressional elections. ${ }^{144}$ By contrast, Article II gives Congress the power to determine only the time of choosing the electors and the day on which they vote. ${ }^{145}$

But any reading of Article II must be tempered by the realization that we no longer live under the original Constitution. The adoption of the Fourteenth, Fifteenth, Nineteenth, Twenty-Fourth, and Twenty-Sixth Amendments has vastly increased the power of Congress to regulate state elections. The question, then, is whether these provisions, and in particular the Fourteenth and Fifteenth Amendments, give Congress any authority over the states' choices of electoral systems. The Supreme Court's precedents on this subject clearly suggest that, although the states' power to regulate the manner of appointment of electors is extensive, it is not absolute.

The Court first considered the applicability of the Reconstruction amendments to the electoral system in McPherson v. Blacker. ${ }^{146}$ That case dealt with the constitutionality of the Michigan legislature's decision to abandon the winner-take-all system of choosing presidential electors and to adopt a congressional-district system. The plaintiffs argued that this decision violated Article II and the Fourteenth and Fifteenth Amendments. First, they contended that Article II compelled the use of the winner-take-all system because it specified that the "State" must appoint the electors, and that the

143. In early elections, Alabama, Georgia, Mississippi, Missouri, New Hampshire, New Jersey, and Rhode Island used the general-ticket system for choosing House members. Joel F. Paschal, The House of Representatives: "Grand Depository of the Democratic Principle"?, 1952 LAW \& CONTEMP. PROBS. 276. 281; see also DE ALVA S. AlEXANDER, HISTORY AND PROCEDURE OF THE HOUSE OF REPRESENTATIVES 4 (1916); Clarence G. Hoag \& George H. Hallett JR., Proportional Representation 34, 40 (1926). Concern that larger states might try to enhance their influence by adopting the system led Congress to mandate in 1842 that states choose Representatives from contiguous single-member districts. Paschal, supra, at 281. This decision touched off something of a constitutional crisis when four states, Georgia, Mississippi, Missouri, and New Hampshire, refused to comply with the law. Id. at 281-82. Congress has subsequently altered and amended the single-member-district requirement numerous times. The current version, adopted in 1967, is codified at 2 U.S.C. \$ $2 \mathrm{c}$ (1983). Although states have in the past elected Representatives at large in violation of these statutes, Congress has never refused to seat anyone so chosen. Paschal, supra, at 285.

144. See U.S. CONST. art. I, $\S 4, \mathrm{cl}$. I. The one exception to this power is that Congress may not determine the place of choosing Senators, who under the original Constitution were chosen by the legislatures. See U.S. CONST. art. I, § 3, cl. 1, amended by id. amend. XVII (providing for direct election of Senate).

145. Id. art. II, \$ 1, cl. 4.

146. 146 U.S. 1 (1892). 
state was an individual unit. The court soundly rejected this argument, reasoning that:

If the legislature possesses plenary authority to direct the manner of appointment, and might itself exercise the appointing power ... it is difficult to perceive why, if the legislature prescribes as a method of appointment choice by vote, it must necessarily be by general ticket and not by districts. ... [T] he act of appointment is none the less the act of the State in its entirety because arrived at by districts, for the act is the act of political agencies duly authorized to speak for the State, and the combined result is the expression of the voice of the State, a result reached by direction of the legislature, to whom the whole subject is committed. ${ }^{147}$

Noting that the district system had been contemplated by the Framers and that it and the legislative-selection method had been used in several past elections, ${ }^{148}$ the Court concluded that

the appointment and mode of appointment of electors belong exclusively to the States under the Constitution of the United States. ... Congress is empowered to determine the time of choosing the electors and the day on which they are to give their votes, .... but otherwise the power and jurisdiction of the State is exclusive. ${ }^{149}$

If this language were the Supreme Court's final word on the interpretation of Article II, it would clearly suggest that Congress has no power to regulate the electoral process. Carried to its logical extreme, however, this argument would produce some very dubious results. Suppose, for example, that a state enacted a literacy test or poll tax for potential voters in presidential elections expressly designed to disenfranchise racial minorities. Or, for that matter, suppose that a state simply banned African-Americans from voting for President. Such an enactment would clearly violate Section 1 of the Fifteenth Amendment. Under Section 2 of the Amendment, Congress is empowered to enforce Section 1 by "appropriate legislation." Such legislation is clearly constitutional when applied to elections for other state offices. Yet, a strict reading of McPherson would mean that the enforcement provision of the Fifteenth Amendment is invalid in the case of presidential elections-surely an anomalous result.

Indeed, in its analysis of the plaintiffs' Fourteenth and Fifteenth Amendment claims, the McPherson Court immediately qualified its strict

147. Id. at 25-26.

148. Id. at $28-35$.

149. Id. at 35 . 
reading of Article II. Although it found no violation of either amendment, ${ }^{150}$ it left no doubt that the Fourteenth Amendment does place limits on the Article II powers of state legislatures:

Whenever presidential electors are appointed by popular election, then the right to vote cannot be denied or abridged without invoking the penalty [in Section 2 of the Fourteenth Amendment], and so of the right to vote for representatives in Congress, the executive and judicial officers of a State, or the members of the legislature thereof. ${ }^{151}$

The Court did not return to this issue for another seventy-six years. When it did, however, it clearly confirmed the applicability of the Fourteenth Amendment to the electoral system. In Williams $v$. Rhodes, ${ }^{152}$ two independent parties in Ohio-George Wallace's American Independent party and the Socialist Labor party-challenged a series of election laws that made it "virtually impossible" for minor parties to be placed on the presidential ballot. ${ }^{153}$ The plaintiffs argued that such restrictions violated the Equal Protection Clause. In response, the state relied on McPherson, claiming that Article $\Pi$ gave it "absolute power to put any burdens it please[d] on the selection of electors." 154

The Williams Court rejected the state's argument for a broad interpretation of its Article II power, reasoning that

[t]here, of course, can be no question but that this section does grant extensive power to the States to pass laws regulating the selection of electors. But the Constitution is filled with provisions that grant Congress or the States specific power to legislate in certain areas; these granted powers are always subject to the limitation that they may not be exercised in a way that violates other specific provisions of the Constitution.... [I]t [cannot] be thought that the power to select electors could be exercised in such a way as to violate express constitutional commands that specifically bar States from passing certain kinds of laws. Clearly, the Fifteenth and Nineteenth Amendments were intended to bar the Federal Government and the States from denying the right to vote on grounds of race and sex in presidential elections. And the Twenty-fourth Amendment clearly and literally bars any State from imposing a poll tax on the right to vote "for electors for President or Vice President." Obviously, we must

150. The plaintiffs' argument was that the congressional-district system abridged the right of votingage male citizens to vote for electors, in that the winner-take-all system allowed them to vote for the entire slate, rather than only for three electors. Id. at 17 (discussing argument for Plaintiffs in Error). The Court rejected this argument on the grounds that the district system treated all voters equally. Id. at 40 .

151. Id. at 39 .

152. 393 U.S. 23 (1968).

153. Id. at 25 .

154. Id. at 28. 
reject the notion that Art. II, $\S 1$ gives the States power to impose burdens on the right to vote, where such burdens are expressly prohibited in other constitutional provisions. We therefore hold that no State can pass a law regulating elections that violates the Fourteenth Amendment's command that "No State shall ... . deny to any person ... the equal protection of the laws."155

Williams thus leaves no room for doubt that the Fourteenth and Fifteenth Amendments place affirmative restrictions on states' discretion to choose the manner in which they appoint presidential electors.

Neither Williams nor McPherson, however, directly addressed the scope of Congress's power to regulate state selection of presidential electors under the Fourteenth and Fifteenth Amendments. The fact that the amendments do place limits on state discretion, however, strongly suggests that Congress has authority to enact "appropriate legislation" under Section 5 of the Fourteenth Amendment and Section 2 of the Fifteenth Amendment. ${ }^{156}$

Does that authority extend to regulation of the electoral system? The most logical reading of the Constitution suggests that it does. After all, under the original Constitution, Congress had no explicit power to regulate any aspect of state or local elections, whether for governor, city councillor, or dogcatcher. The Framers certainly intended that such matters would remain the domain of the states, and that the federal government would not get involved. ${ }^{157}$ In this respect, there is nothing unusual about Article II. Appointment of presidential electors is the exclusive domain of the states to precisely the same degree as is the election of legislators and other state officers.

Essentially, then, the question of the applicability of the Voting Rights Act to the electoral system is no different from the question of the underlying constitutionality of the Act as a whole-a question that the Court settled long ago in Katzenbach v. Morgan. ${ }^{158}$ In Katzenbach, voters in New York City challenged the constitutionality of $\S 4(e)$ of the Act, ${ }^{159}$ which restricted the use of literacy tests as a prerequisite to voter registration. The state argued that the Act exceeded the scope of Congress's enforcement power because the

155. Id. at 29 (final two omissions in original); see also Anderson v. Celebrezze, 460 U.S. 780, 794-95 n.18 (1983) (citing Williams approvingly).

156. See, e.g., City of Richmond v. J.A. Croson Co., 488 U.S. 469, 490 (1989) (noting that Congress "has a specific constitutional mandate to enforce the dictates of the Fourteenth Amendment").

157. See Oregon v. Mitchell, 400 U.S. 112, 125 (1970) (opinion of Black, J., announcing judgments of the Court):

It is a plain fact of history that the Framers never imagined that the national Congress would set the qualifications for voters in every election from President to local constable or village alderman. It is obvious that the whole Constitution reserves to the States the power to set voter qualifications in state and local elections, except to the limited extent that the people through constitutional amendments have specifically narrowed the powers of the States.

158. 384 U.S. 641 (1966).

159. 42 U.S.C. $\S 1973 \mathrm{~b}(\mathrm{e})(1988)$. 
judiciary had not found a Fourteenth or Fifteenth Amendment violation. ${ }^{160}$ The Court soundly rejected that argument, holding that:

A construction of $\S 5$ [of the Fourteenth Amendment] that would require a judicial determination that the enforcement of the state law precluded by Congress violated the Amendment, as a condition of sustaining the congressional enactment, would depreciate both congressional resourcefulness and congressional responsibility for implementing the Amendment. It would confine the legislative power in this context to the insignificant role of abrogating only those state laws that the judicial branch was prepared to adjudge unconstitutional, or of merely informing the judgment of the judiciary by particularizing the majestic generalities of $\S 1$ of the Amendment. ${ }^{161}$

Instead, the Court held that Congress's power under the Fourteenth Amendment is as broad as its power under the Necessary and Proper Clause of Article I: "Correctly viewed, $\S 5$ is a positive grant of legislative power authorizing Congress to exercise its discretion in determining whether and what legislation is needed to secure the guarantees of the Fourteenth Amendment." 162

Katzenbach, of course, does not deal specifically with congressional protection of the right to vote in presidential elections, but rather with protection of the right to vote in general. A strict interpretation of McPherson would have required the Court to hold that, while Congress may ban literacy tests as a prerequisite for voting in other state elections, it may not ban them in presidential elections. Although this would be a strange result, it would certainly be a plausible reading of Article II. Nowhere in Katzenbach, however, does the Court explicitly state that its holding does not apply to presidential elections.

Moreover, in Oregon v. Mitchell, a case involving the constitutionality of several amendments that Congress added to the Voting Rights Act in 1970, the Court reached just the opposite result, holding that Congress had more power to regulate presidential and congressional elections than elections for state and local office. ${ }^{163}$ The 1970 amendments to the Act lowered the voting age to eighteen in both state and federal elections, barred the use of literacy tests in all elections, and barred states from disqualifying voters in national elections for failure to meet state residency requirements. All of the Justices agreed that

160. Katzenbach, 384 U.S. at 648.

161. Id. at $648-49$ (internal quotations and citations omitted).

162. Id. at 651; see also Jones v. City of Lubbock, 727 F.2d 364, 373-75 (5th Cir. 1984) (upholding constitutionality of 1982 amendments to $\S 2$ of Voting Rights Act and noting that "Congressional power to adopt prophylactic measures to vindicate the purposes of the fourteenth and fifteenth amendments is unquestioned"); United States v. Uvalde Consol. Indep. Sch. Dist., 625 F.2d 547, 553 (5th Cir. 1980) (holding pre-1982 language of $\S 2$ to be within Congress's Fourteenth Amendment power).

163. 400 U.S. 112, 117-18 (1970) (opinion of Black. J., announcing judgments of the Court). 
the ban on literacy tests was constitutional as applied to all elections. Eight of the nine agreed that the regulations relating to residency requirements and absentee voting in presidential elections were constitutional. ${ }^{164}$ Four Justices held that the voting-age requirements were constitutional as applied to all elections, while another four concluded that Congress had no authority to override state voting-age requirements. Justice Black, who cast the deciding vote, agreed with the first group with respect to "national elections, such as congressional, senatorial, vice-presidential and presidential elections," but with the second group concerning elections for state and local offices. ${ }^{165}$ Hence the majority was willing to extend more power to Congress over presidential elections than over state elections.

Justice Black, who had written the majority opinion in Williams just two years earlier, was not troubled by the notion that Article II constrains congressional power over presidential elections. His Mitchell opinion dismissed this proposition out of hand, claiming that "it cannot be seriously contended that Congress has less power over the conduct of presidential elections than it has over congressional elections." ${ }^{166}$ Congressional power over presidential elections, in Justice Black's view, is obvious since "inherent in the very concept of a supreme national government . . . is a residual power in Congress to insure that those officers [electors] represent their national constituency as responsively as possible. This power arises from the nature of our constitutional system of government and from the Necessary and Proper Clause."167

Justice Black's invocation of the Necessary and Proper Clause, rather than the enforcement clauses of the Fourteenth and Fifteenth Amendments, is significant. His objection to the eighteen-year-old voting age was that it was not sufficiently linked to race to come within the ambit of the Reconstruction amendments. ${ }^{168}$ Like all of the other Justices, however, he believed that Congress's specific findings concerning the racially discriminatory impact of

164. Justice Farlan was the lone dissenter on this issue. Id. at 154, 213-16 (Harlan, J., concurring in part and dissenting in part).

165. Id. at 117-18 (opinion of Black, J.). This holding was overturned by the Twenty-Sixth Amendment, which provides: "The right of citizens of the United States, who are eighteen years of age or older, to vote shall not be denied or abridged by the United States or by any State on account of age." U.S. CONST. amend. XXVI, $\$ 1$.

166. Mitchell, 400 U.S. at 124 (opinion of Black, J.)

167. Id. at 124 n.7 (opinion of Black, J.). Justice Black also relied on the Court's opinion in Burroughs v. United States, 290 U.S. 534 (1934), which held that Congress had the power to enact criminal statutes requiring the treasurer of a political committee involved in a presidential election to report contributions and other financial information.

168. Mitchell, 400 U.S. at 130 (opinion of Black, J.) ("Congress made no legislative findings that the 21-year-old vote requirement was used by the States to disenfranchise voters on account of race. I seriously doubt that such a finding, if made, could be supported by substantial evidence."). 
literacy tests provided an ample basis for a ban on these tests in all elections-including, presumably, presidential elections. ${ }^{169}$

The absentee voting provisions-which applied exclusively to presidential elections-similarly met with no objection from eight of the nine Justices. Justice Black again concluded that the absentee voting provisions were justified under the Necessary and Proper Clause. ${ }^{170}$ Justice Stewart, joined by Chief Justice Burger and Justice Blackmun, agreed. ${ }^{171}$ With respect to Article II, Justice Stewart noted that setting voter qualifications in presidential elections is generally a state prerogative. ${ }^{172} \mathrm{He}$ concluded, however, that this provision was "not sufficient to prevent Congress from protecting a person who exercises his constitutional right to enter and abide in any State in the Union from losing his opportunity to vote, when Congress may protect the right of interstate travel from other less fundamental disabilities." "173 Justice Douglas considered the provisions a valid exercise of congressional power under the Fourteenth Amendment, ${ }^{174}$ and Justices Brennan, White, and Marshall reached a similar conclusion. ${ }^{175}$ Justice Harlan, dissenting on this point, argued that the Fourteenth Amendment did not protect the right to vote. ${ }^{176}$

The primary disagreements in Mitchell thus did not revolve around whether Congress had the power to enact appropriate legislation that would regulate state elections-including presidential elections. Rather, the split among the Justices reflected disagreement as to whether the legislation that Congress had enacted was, in fact, appropriate. All of the Justices agreed that when Congress is acting to combat racial discrimination, it can legitimately regulate state elections, and none of them expressed the slightest reservation about extending the ban on literacy tests to presidential elections. In fact, the ultimate outcome in Mitchell suggests that congressional power to regulate presidential elections through the Voting Rights Act is, if anything, greater than its power to regulate state elections. Mitchell thus presents a powerful case for rejecting a strict reading of McPherson. ${ }^{177}$

169. Id. at 131-34 (opinion of Black, J.); see also id. at 144-47 (Douglas, J., concurring in part and dissenting in part); id. at 216-17 (Harlan, J., concurring in part and dissenting in part) (finding literacy test ban to be valid exercise of congressional power under Fifteenth Amendment); id. at 231-36 (Brennan, White \& Marshall, JJ., concurring in part and dissenting in part); id. at 282-84 (Stewart, J., concurring in part and dissenting in part).

170. Id. at 134 (opinion of Black, J.).

171. Id. at 285-87 (Stewart, J., concurring in part and dissenting in part).

172. Id. at 291 (Stewart, J., concurring in part and dissenting in part).

173. Id. at 292 (Stewart, J., concurring in part and dissenting in part).

174. Id. at 150 (Douglas, J., concurring in part and dissenting in part).

175. Id. at 236-39 (Brennan, White \& Marshall, JJ., concurring in part and dissenting in part).

176. Id. at 213-16 (Harlan, J., concurring in part and dissenting in part).

177. The continuing vitality of the holding in Mitchell is illustrated by two recent decisions upholding the constitutionality of the National Voter Registration Act, 42 U.S.C. $\$ \S 1973 g g$ to $1973 \mathrm{gg}-10$ (Supp. 1993), popularly known as the "motor-voter" act. Under this statute, states are required to implement a number of procedures designed to make it easier for people to register to vote in "federal elections," 42 U.S.C. \$ 1973gg-1(2) (1994), a term that is defined to include both congressional and presidential elections. see 2 U.S.C. $\$ 431(3)$ (1994). 
Of course, Article II does place some important limits on the power of the federal government to determine the manner of appointment of presidential electors. Even under a loose reading of McPherson, it would be hard to argue that Congress or the federal courts have the authority to supersede the state legislatures entirely and require a particular mode of election. The principle that the ultimate responsibility for adopting a valid electoral scheme rests with the state is well established in voting rights cases involving both the Voting Rights Act and the Equal Protection Clause. ${ }^{178} \mathrm{~A}$ court may find that a particular scheme is illegal and enjoin its further use, but absent extraordinary circumstances, such as a state's willful failure to remedy the problem, it may not institute its own plan as a remedy. Proper respect for principles of federalism would dictate that, while Congress might place restrictions on the electoral system, neither Congress nor the federal courts could dictate that all states employ a particular system-say, for example, the proportional system. ${ }^{179}$ Restricting the use of racially discriminatory voting systems, however, is well within the scope of congressional power.

In both Association of Community Organizations for Reform Now v. Edgar, 56 F.3d 791 (7th Cir. 1995), and Voting Rights Coalition v. Wilson, 60 F.3d 1411 (9th Cir. 1995), courts upheld the constitutionality of these provisions. Both courts specifically held that congressional power to regulate presidential elections is coextensive with its power to regulate congressional elections under Article I. See id. at 1414; Edgar, 56 F.3d at 793. Neither court relied on Mitchell, however. Instead, they relied, like Justice Black in Mitchell, on Burroughs v. United States, 290 U.S. 534 (1934). As noted above, Burroughs dealt with a federal statute requiring officials of political committees involved in presidential campaigns to report contributions and other financial information, and providing criminal penalties for noncompliance. The Court held that these provisions did not violate the language of Article II granting legislatures the power to determine the manner of appointment of presidential electors. Id. at 544-45. The Court did not mention Article I, but instead found that Congress had a residual power "to preserve the departments and institutions of the general government from impairment or destruction, whether threatened by force or by corruption." Id. at 545 .

Burroughs thus does not appear to provide any strong support for Judge Posner's holding in Edgar that congressional power over presidential elections is coextensive with its Article I power or the similar pronouncement in Wilson. If these decisions are correct, then McPherson is no longer good law, and Congress has essentially plenary power over the time, place, and manner of presidential elections, just as it does over congressional elections.

Interestingly, the only reference to Mitchell in either Edgar or Wilson is a reference to Justice Black's conclusion that Article I, Section 2 of the Constitution precludes Congress, as a general matter, from setting voter qualifications for state offices. See Wilson, 60 F.3d at 1414 (citing Mitchell, 400 U.S. at 123-25).

178. See, e.g., Growe v. Emison, 113 S. Ct. 1075, 1081 (1993) (holding that district court erred in $\$ 2$ case by enjoining state redistricting process); Chapman v. Meier, 420 U.S. 1, 27 (1975):

We say once again what has been said on many occasions: reapportionment is primarily the duty and responsibility of the State through its legislature or other body, rather than of a federal court. ... If [the legislature] fails in that task, the responsibility falls on the District Court and it should proceed with dispatch to resolve ... [the] problem.

179. This approach to congressional authority is similar to that taken by one recent commentator on the electoral system, who concluded that Congress would have power under the Fourteenth Amendment to enact a statute specifically banning the winner-take-all system. See O'Sullivan. supra note 12, at $2446-47$. O'Sullivan's proposal, however, overlooks the possibility that Congress may already have passed such a statute in $\S 2$ of the Voting Rights Act. 


\section{B. Statutory Authority}

The mere fact that Congress has constitutional authority to regulate the electoral system does not, of course, imply that Congress has actually exercised that authority. Whether $\S 2$ of the Voting Rights Act applies to these processes involves questions of statutory interpretation. At the outset of this analysis, however, it is worth reiterating that the winner-take-all system is precisely the kind of electoral scheme that Congress was contemplating when it passed the 1982 amendments: an at-large scheme over which a majority faction can exercise complete control. ${ }^{180}$ Thus the case for applying $\S 2$ to the winnertake-all system is much stronger than the case for applying it to a gerrymandered system of single-member districts, a practice the Supreme Court has explicitly approved on several recent occasions. ${ }^{181}$

As noted above, the text of Article II authorizes the states to "appoint" electors. Although all of the states have now instituted popular election as a mode of appointment, the term "appoint" poses a possible problem for the $\S 2$ analysis because most courts hold that the statute does not apply to appointive offices. ${ }^{182}$ One might therefore argue that the statute does not apply to a state's "appointment" of presidential electors, whether it exercises that authority directly or delegates it to its citizens.

The logical response to this argument is that, while states need not exercise their appointment power through a popular vote, when they do choose to hold popular elections, they become subject to all of the constitutional and statutory rules that govern elections-including the Voting Rights Act. The text of $\S 2$ (a) tends to support this analysis. Congress drafted $\S 2$ in extremely broad language, to apply to any "voting qualification or prerequisite to voting or standard, practice, or procedure."183 In literal terms, the statute does not even require that the "standard, practice, or procedure" be related to voting. ${ }^{184}$

180. The legislative history of $\$ 2$ makes it clear that Congress primarily intended to overturn City of Mobile v. Bolden, 446 U.S. 55 (1980), and restore the "results" test that courts had previously employed. See S. REP. No. 417, supra note 135, at 15-17. Like Mobile, the line of cases that Congress was attempting to restore dealt exclusively with the problem of vote dilution in at-large systems. See White v. Regester, 412 U.S. 755 (1973); Whitcomb v. Chavis, 403 U.S. 124 (1971); Zimmer v. McKeithen, 485 F.2d 1297 (5th Cir. 1973), aff'd on other grounds sub nom. East Carroll Parish Sch. Bd. v. Marshall, 424 U.S. 636 (1976); see also S. REP. No. 417, supra note 135, at 19-24 (analyzing these and other cases involving atlarge elections).

181. See supra note 138 and accompanying text.

182. See, e.g., African-American Citizens for Change v. St. Louis Bd. of Police Comm'rs, 24 F.3d 1052, 1053-54 (8th Cir. 1994).

Section 5 of the Voting Rights Act would apply in situations where a covered jurisdiction changed the mode of selection for an office from election to appointment, or vice versa. See supra note 135 . Without preclearance from either the Justice Department or the U.S. District Court for the District of Columbia, such a change would be unenforceable. See Allen v. State Bd. of Elections, 393 U.S. 544, 549-50 (1969); see also Presley v. Etowah County Comm'n, 502 U.S. 491, 501 (1992) (reaffirming Allen with respect to change from elective to appointive office).

183. 42 U.S.C. $\$ 1973($ a) (1994).

184. Cf. Voting Rights Act $\$ 5,42$ U.S.C. $\$ 1973 c$ (1994) (covering any "standard, practice, or procedure with respect to voting"). 
Does a binding election to fill the post of presidential elector meet this standard? The Supreme Court's analysis of $\S 2$ 's applications to judicial elections provides a helpful comparison. Like presidential electors, judges do not exercise a legislative function, and need not be elected. In general, a state has absolute freedom to decide at any point that any judicial position on any court be filled by appointment. One might therefore plausibly argue that judicial elections do not come within the ambit of $\S 2$.

The Supreme Court, however, soundly rejected that argument with respect to both trial and appellate judges. In Chisom v. Roemer ${ }^{185}$ and Houston Lawyers' Association v. Attorney General, ${ }^{186}$ the defendants argued that $\S 2$ did not apply to at-large elections for judicial positions, on the theory that judges are supposed to dispense justice evenhandedly, and hence are not "representatives" within the meaning of $\$ 2$ (b). In analyzing this argument, the Court first concluded that $\S 2$, including the 1983 amendments, applies to judicial elections. ${ }^{187}$ It then considered whether the use of the term "representative" in § 2(b) operated to limit the applicability of the totality-ofthe-circumstances test in judicial elections. Noting that Congress modeled the language of $\S 2$ (b) on the Court's language in White v. Regester, ${ }^{188}$ the Court focused on a crucial distinction: the substitution-made at the behest of Senator Robert Dole, a key backer of the 1982 amendments-of the word "representatives" for the word "legislators." 189 The Court held that if the term "representatives" applied to executive officers, as the state conceded it did, then it should also apply to judicial officers. ${ }^{190}$ The Court continued:

The [Fifth Circuit] was, of course, entirely correct in observing that "judges need not be elected at all" and that ideally public opinion should be irrelevant to the judge's role because the judge is often called upon to disregard, or even to defy, popular sentiment.... Louisiana, however, ... . has decided to elect its judges and to compel judicial candidates to vie for popular support just as other political candidates do.

... When each of several members of a court must be a resident of a separate district, and must be elected by the voters of that district,

Justice Thomas has recently expressed the view that the words "standard, practice, or procedure" in $\S 2$ should be understood to mean "standard, practice, or procedure with respect to voting"-rather a strange reading for a supposed textualist. See Holder v. Hall, 114 S. Ct. 2581, 2603 (1994) (Thomas, J., concurring in judgment).

185. 501 U.S. 380 (1991).

186. 501 U.S. 419 (1991).

187. Chisom. 501 U.S. at 395-96. Prior to its decision in Chisom. the Court had held that $\$ 5$ of the Voting Rights Act, which requires judicial or administrative preclearance of any change in any "standard, practice, or procedure with respect to voting," did apply to judicial elections. Clark v. Roemer, 500 U.S. 646,652 (1991).

188. 412 U.S. 755 (1973).

189. Chisom, 501 U.S. at 398 \& n.26.

190. Id. at 398-400. 
it seems both reasonable and realistic to characterize the winners as representatives of that district. ${ }^{191}$

The Court rejected an alternative interpretation of "representative" offered by Justice Scalia, who, in a dissent joined by Chief Justice Rehnquist and Justice Kennedy, argued that "the ordinary meaning of 'representatives' does not include judges," because judges do not act "on behalf of the people"-at least not in the ordinary sense of those words. ${ }^{192}$

Even under Justice Scalia's more restrictive definition, it is hard to see how presidential electors would not be "representatives" when they are chosen by popular vote. Unlike judges, electors do not customarily exercise any independent judgment. Their sole function in the modern system is to serve as proxies for actual voters. In Justice Scalia's language, they cast their ballots "on behalf of" the people of their state. Chisom thus strongly suggests that presidential electors are "representatives" within the meaning of the statute. So long as the state chooses to exercise its appointment power through a popular vote, it remains subject to the Voting Rights Act.

The Court faced a related question concerning the scope of $\S 2$ in Holder v. Hall. ${ }^{193}$ That case involved the applicability of the Act to single-member offices: specifically, a single-commissioner form of government used by a rural county in central Georgia. Under this form of government, the commissioner performs all legislative and executive functions. ${ }^{194}$ With racially polarized voting patterns, the single-commissioner form of government, like an at-large system, can give the majority complete control over the political structure. The typical remedy for vote dilution in an at-large system, however, is to break it up into single-member districts. Obviously, that could not be done in Holder without increasing the size of the governing body. That move, however, would have raised potentially significant problems. Suppose, for example, that the minority population of a county is big enough to enable it to constitute a majority in one district in an eleven-member system, but not big enough to enable it to constitute a majority in one district in a five-member system. Is that county required to adopt an eleven-member system, rather than a fivemember system? If so, can the county next door, which already has a fivemember system, be compelled to adopt an eleven-member system? Can another county with an even smaller black population be forced to adopt a twentymember system?

Faced with these questions, the Court rejected the Holder plaintiffs' claim but divided sharply in its reasoning. Justice Kennedy, joined by Chief Justice Rehnquist and joined in pertinent part by Justice O'Connor, held that plaintiffs

191. Id. at 400-01 (citation omitted).

192. Id. at 410 (Scalia, J., dissenting).

193. 114 S. Ct. 2581 (1994).

194. Id. at 2584 (plurality opinion). 
cannot challenge the size of a governing body under $\S 2$ because there is no "objective and workable standard for choosing a reasonable benchmark by which to evaluate a challenged voting practice ...."195 Justice O'Connor, in a separate opinion, reiterated the need for a "reasonable alternative practice as a benchmark." 196 Justice Kennedy and Justice O'Connor differed slightly as to the threshold coverage of $\S 2$, however. Noting that the Court's $\S 5$ cases may be interpreted to assert that a change in the size of a governing body is a "standard, practice, or procedure with respect to voting" that must be precleared in a jurisdiction covered by $\S 5$, Justice Kennedy argued that a voting practice that can be challenged under $\S 5$ is not necessarily subject to challenge under the similar language of $\S 2 .{ }^{197}$ Justice O'Connor, however, argued that the similarity in language between $\S 2$ and $\S 5^{198}$ of the Voting Rights Act compelled the conclusion that the threshold coverage of the two is the same: "As a textual matter, I cannot see how a practice can be a 'standard, practice, or procedure with respect to voting,' yet not be a 'standard, practice, or procedure."'199 Justices Scalia and Thomas provided the two votes necessary to complete the majority. In a lengthy opinion by Justice Thomas, however, they endorsed a radically different interpretation of the Act. They suggested that the words "standard, practice, or procedure" should apply only to direct barriers to the right to vote, notwithstanding twenty-five years of contrary precedent and Congress's repeated reenactment of the same language during that period. ${ }^{200}$ The remaining four Justices, in a dissenting opinion by Justice Blackmun, accepted in principle the requirement of a reasonable alternative benchmark but felt that, under the particular facts of the case, a five-member commission was an appropriate benchmark. ${ }^{201}$ They also agreed with Justice O'Connor's conclusion that size was a "standard, practice, or procedure" subject to challenge under $\S 2$. $^{202}$

Several holdings that relate to the electoral system can be drawn from this rather tangled web of judicial explication. First, in the view of five Justices, the "standard, practice, or procedure" language of $\S 2$ is to be construed broadly. Congress intended the statute to apply to any standard, practice, or procedure, or at least to any standard, practice, or procedure within the meaning of $\S 5$. The winner-take-all system clearly falls within this statutory language and hence within the ambit of the Act.

Second, elections for single-member offices generally cannot be challenged under $\S 2$. At first glance, this holding might seem to bar any challenge to

195. Id. at 2586 (plurality opinion).

196. Id. at 2589 (O'Connor. J.. concurring).

197. Holder, $114 \mathrm{~S}$. Ct. at 2586-87 (plurality opinion).

198. For a description of $\S 5$, see supra note 135 .

199. Holder, 114 S. Ct. at 2589 (O'Connor, J., concurring).

200. Id. at 2592 (Thomas, J., concurring).

201. Id. at 2622 (Blackmun, J., dissenting).

202. Id. at 2621 (Blackmun, J., dissenting). 
presidential elections. As a matter of law, however, ordinary citizens do not and may not vote for President. They vote for presidential electors, to whom our Constitution entrusts the task of choosing the Chief Executive. The office of presidential elector is not a single-member office in any jurisdiction. Rather, the number of electors to be chosen is fixed by the Constitution in a manner that ensures that each state will choose at least three electors.

Third, a plaintiff challenging a "standard, practice, or procedure" under $\$ 2$ must be able to identify a reasonable alternative benchmark. In the case of a winner-take-all system, either the proportional or the congressional-district system will always be available as a benchmark. In some respects, the district system might seem to be the most appropriate benchmark, since it is similar to the single-member-district standard the Court has consistently used in other challenges to at-large systems. Neither of these standards creates the kind of open-ended problems that a challenge to the size of a governing body necessitates. In the Court's language, both benchmarks are simple, objective, workable, and reasonable.

In sum, there is no constitutional or statutory reason to think that $\S 2$ of the Voting Rights Act does not apply to a state's decision to use the winnertake-all system for the appointment of presidential electors. The next question to be answered is whether, and where, the winner-take-all system violates $\S 2$.

\section{THE § 2 ANALYSIS}

The mere fact that a jurisdiction operates an at-large or multimember electoral system is not sufficient to establish a violation of $\S 2 .^{203}$ Instead, the amended statute directs courts to look at the totality of the circumstances in making this determination. A finding of vote dilution must rest on specific evidence that a particular electoral scheme actually operates to cancel or minimize the voting strength of a protected minority group: "The essence of a $\S 2$ claim is that a certain electoral law, practice, or structure interacts with social or historical conditions to cause an inequality in the opportunities enjoyed by black and white voters to elect their preferred representatives."204 It is thus entirely possible for an electoral system to be legal in one state and yet, as a result of different social, economic, or political characteristics, to be illegal in another. Determining whether the winner-take-all system violates the Act therefore requires a highly fact-specific inquiry that is intensely sensitive to the peculiarities of various states.

203. Thornburg v. Gingles, 478 U.S. 30, 48 (1986) ("Multimember districts and at-large election schemes . . . are not per se violative of minority voters' rights."); see also Rogers v. Lodge, 458 U.S. 613 , 617 (1982) (holding that although at-large and multimember schemes may potentially violate rights of minority voters, they are not per se violative of Equal Protection Clause).

204. Gingles, 478 U.S. at 47. 
This Article does not attempt a definitive analysis of voting patterns in each of the fifty states. It does, however, attempt to identify those states that are potentially vulnerable to a $\$ 2$ challenge. To that end, this part makes use of exit poll data from both nationwide and statewide surveys. It also provides a somewhat more detailed analysis of voting patterns in four states: Alabama, California, Illinois, and New York. These states differ from one another in terms of demographics, history, and political characteristics. One might therefore expect to see significant differences in voting behavior among them that might affect the $\$ 2$ inquiry. Alabama, for example, lies in the heart of the Deep South, where discrimination against African-Americans has been most severe. It is one of only two states-Mississippi being the other-whose electors cast votes for Strom Thurmond in 1948, Harry Byrd in 1960, and George Wallace in 1968. Moreover, in the last three elections, Alabama has consistently voted Republican.

In contrast, the histories of official discrimination in California, Illinois, and New York are not as extensive; however, each state has a large minority community that historically has faced substantial barriers to social and political equality. California and New York, moreover, both have significant Hispanic populations-largely Mexican-Americans in the case of California, and Puerto Ricans in the case of New York. The presence of two or more minority groups, whose interests and voting behavior may or may not coincide, can pose complicated questions for the vote-dilution inquiry. Moreover, the political histories of these states are quite different. California and Illinois have historically been "swing" states, considered crucial to the success of any political campaign, while New York has tended to be a Democratic stronghold.

Before proceeding to an analysis of these states, however, it is necessary to examine the legal framework that courts have developed for analyzing § 2 claims. Section A sets out these standards and analyzes voting behavior at the national level in an attempt to determine which states, if any, might be vulnerable to a $\$ 2$ challenge. Section $B$ then examines statewide patterns in the four states listed above and attempts to determine whether a $\S 2$ challenge in those states would be likely to succeed.

\section{A. Legal Standards}

The most important legal standards for analyzing vote-dilution claims under $\S 2$ derive from the Supreme Court's 1986 decision in Thornburg $v$. Gingles, ${ }^{205}$ the first case in which the Court addressed the scope of the 1982 amendments. In Gingles, the Court identified a set of three threshold 
conditions that plaintiffs must meet in order to demonstrate a violation of the Act. The three "Gingles factors" are as follows:

First, the minority group must be able to demonstrate that it is sufficiently large and geographically compact to constitute a majority in a single-member district. If it is not, as would be the case in a substantially integrated district, the multimember form of the district cannot be responsible for minority voters' inability to elect candidates. Second, the minority group must be able to show that it is politically cohesive. If the minority group is not politically cohesive, it cannot be said that the selection of a multimember electoral structure thwarts distinctive minority group interests. Third, the minority group must be able to demonstrate that the white majority votes sufficiently as a bloc to enable it ... usually to defeat the minority's preferred candidate. ${ }^{206}$

The underlying rationale for these conditions is straightforward. The Gingles analysis limits $\S 2$ relief to those minority groups that can demonstrate a potential to elect candidates: "Unless minority voters possess the potential to elect representatives in the absence of the challenged structure or practice, they cannot claim to have been injured by that structure or practice."207

The three-part Gingles analysis is now firmly established in the Court's $\S 2$ jurisprudence. ${ }^{208}$ Proof of the Gingles factors, however, is not sufficient to establish liability under $\S 2$. In accordance with the explicit language of $\S 2(b)$, plaintiffs must still demonstrate that, given the totality of the circumstances, they have "less opportunity than other members of the electorate to participate in the political process and to elect representatives of their choice." 209 Accordingly, this section reviews the application of each of the three Gingles factors as well as the "totality of the circumstances" test.

\section{Numerosity and Geographical Compactness}

The first of the three Gingles factors seems relatively straightforward. To make out a $\$ 2$ violation, a minority group must be able to show that it is possible to draw a single-member district in which members of the group constitute a majority. In the background, however, lurk several complicated

206. $I d$. at 50-51 (footnotes and citations omitted). These factors were derived from a law review article written in response to the Mobile decision. See James U. Blacksher \& Larry T. Menefee, From Reynolds v. Sims to City of Mobile v. Bolden: Have the White Suburbs Commandeered the Fifteenth Amendment?, 34 HASTINGS L.J. 1, 51-60 (1982).

207. Gingles, 478 U.S. at 50 n.17.

208. See Johnson v. De Grandy, 114 S. Ct. 2647, 2657 (1994) (applying "now-familiar" Gingles analysis to single-member districting scheme); Voinovich v. Quilter, $113 \mathrm{~S}$. Ct. 1149, 1157-58 (1993) (criticizing court for failure to apply Gingles factors); Growe v. Emison, $113 \mathrm{~S}$. Ct. 1075. 1083-85 (1993) (same).

209. De Grandy, 114 S. Ct. at 2656 (quoting 42 U.S.C. § 1973(b) (1988)). 
questions of interpretation that bear directly on any analysis of the electoral system.

The first question is what it means for a minority group to constitute a "majority" in a district. Does that term mean a majority of the total population-a figure that typically includes numerous people who are ineligible to vote-or does it refer to a majority of some other population measurement? In analyzing the first Gingles factor, courts have usually focused on voting-age population (VAP) because of the Supreme Court's emphasis on the need for minority groups to demonstrate an ability to elect candidates. Since VAP is typically the best available indicator of the number of potential voters in a jurisdiction, courts have reasoned that a minority group does not have an independent ability to elect candidates if it does not constitute a voting-age majority of a district. ${ }^{210}$ Although the Supreme Court has declined to rule that VAP is always the appropriate criterion to use, ${ }^{211}$ it has tended in recent years to go along with the holdings of lower courts on this issue. ${ }^{212}$

The second question is whether the establishment of single-member districts is the only available remedy for a $\$ 2$ violation. The Court's formulation of the first Gingles factor defines liability in terms of this remedy, ${ }^{213}$ but nothing in the text of $\S 2$ indicates that other remedies are not permissible. Several other remedies are possible, and many advocates of minority voting rights claim that these remedies are in fact preferable. ${ }^{214}$

210. See, e.g., McNeil v. Springfield Park Dist., 851 F.2d 937, 945 (7th Cir. 1988), cert. denied, 490 U.S. 1031 (1988); see also GROFMAN ET AL., supra note 118, at 62-64 (noting that VAP has generally been found to be the appropriate measurement for purposes of first Gingles factor).

211. See De Grandy, 114 S. Ct. at 2655-56. The De Grandy case involved a claim by Hispanic voters in Florida. Unlike the Hispanic population in the Northeast, which is largely composed of Puerto Ricans eligible to vote because of their status as U.S. citizens, the Hispanic population of Florida contains large numbers of noncitizens who are ineligible to vote. The state contended in $D e$ Grandy that citizen voting-age population, or "CVAP," was therefore the appropriate measurement for purposes of the first Gingles factor. Id. The Court neither reached the issue of the appropriate measurement of population nor based its ruling on the first Gingles factor, which it assumed had been satisfied in this case. See id.

212. Compare id. at 2658,2663 (examining voting-age population figures) with Gingles, 478 U.S. at 74 n.35 (examining total population figures).

213. See Gingles, 478 U.S. at $50 \mathrm{n} .17$ ("The single-member district is generally the appropriate standard against which to measure minority group potential to elect because it is the smallest political unit from which representatives are elected.").

214. Perhaps the most prominent of these reformers is Lani Guinier, who has argued that singlemember districts tend to produce only token representation. Guinier has advocated a modified at-large system known as cumulative voting as a remedy for vote dilution in at-large systems. See, e.g., Lani Guinier, No Two Seats: The Elusive Quest for Political Equality, 77 VA. L. REv. 1413, 1502-04 (1991). Other modified at-large systems that could be used as remedies are limited voting and the single transferable vote.

Under a cumulative voting system, candidates run for election at large, and each voter can cast as many votes as there are seats to be filled. More than one vote can be cast for a single candidate. Thus, in a nine-member city council race, each voter would receive nine votes and would have the option of casting them all for one candidate or splitting them among several candidates. This system allows minority voters to aggregate their votes behind a limited number of candidates.

Under a limited voting system, candidates also run for election at large. Each voter receives a fixed number of votes, which is less than the total number of seats to be filled. Each ballot must be cast for a different candidate, however. Thus, in a nine-member city council race, each voter might receive five votes, 
Although courts have generally adhered to the single-member-district remedy, a few courts have begun to experiment with alternative remedies as settlement options in $\S 2$ challenges to local government election systems. Should the first Gingles factor be modified to take account of the possibility of alternative remedies?

This question is particularly pressing in the context of the electoral system. A "pure" single-member-district system would be an impractical remedy for vote dilution in a state's electoral college. ${ }^{215}$ It would require every state to develop two redistricting plans: one for its House districts and one for its presidential electors. Because every state has two more presidential electors than it has Representatives, the two plans would have to be different. This would be a very expensive proposition, for redistricting is almost always a time-consuming, politically charged process, and it frequently leads to lengthy litigation. By contrast, the congressional-district system and the proportional system outlined above in Section II.B impose almost no additional expense and would not require states to develop new redistricting plans.

If a district system is the remedy, then any state that currently has a congressional district with a majority of racial minorities in its voting-age population would satisfy the first Gingles factor. Currently, sixteen states have one or more majority-African-American House districts: Alabama, Florida, Georgia, Illinois, Louisiana, Maryland, Michigan, Mississippi, New Jersey, New York, North Carolina, Ohio, Pennsylvania, South Carolina, Tennessee, and Virginia. ${ }^{216}$ Five states have voting-age majority-Hispanic districts:

which could be cast for five different candidates. This limits the majority's ability to fill all nine council seats.

Both cumulative voting and limited voting are usually described as "semiproportional" systems. By contrast, the single transferable vote is frequently described as a "proportional" system. See, e.g., GROFMAN ET AL., supra note 118, at 124-27. Under this method, candidates are elected at large, and voters rank their choices in order of preference. Authorities then determine the threshold number of votes needed for election, based on the number of votes cast. Candidates above the threshold are then declared elected, and their surplus votes are transferred to other candidates, in order of preference, as expressed on the ballots. For various methods of transferring surplus votes, see DOUGLAS J. AMY, REAL CHOICES, NEW VoICES 237-38 (1993). Votes from the remaining candidates with the lowest vote totals are then transferred as well, and any candidate who reaches the threshold is elected. This process continues until the necessary number of candidates are elected. For an interesting account of the use of this system in the United States, see Leon Weaver, The Rise, Decline, and Resurrection of Proportional Representation in Local Governments in the United States, in ELECTORAL LAWS AND THEIR POLITICAL CONSEQUENCES, supra note 130, at 139; see also KathleEn L. BARber, PROPORTIONAL REPRESENTATION \& ELECTORAL REFORM in OHIO (1993).

One unifying feature of all of these systems is that they allow voters to vote for individual candidates, rather than for parties. While this may be a virtue in the typical voting rights case, it is a defect if one is seeking a remedy for vote dilution in a state's electoral college, where the identity of the party-and the candidate at its head-is more important than the identity of the individual elector.

215. For the distinction between the pure single-member-district system and the congressional-district system, see supra Section II.B.

216. CONGRESSIONAL QUaRTERLy INC., CONGRESSIONAL DisTRICTS IN THE 1990S: A PORTRAIT OF AMERICA 19, 166, 203, 234, 318, 338, 373, 415. 465, 496-97, 549, 575, 627, 669, 686, 762 (1993) [hereinafter CONGRESSIONAL DISTRICTS IN THE 1990s].

The Supreme Court recently held that Georgia's congressional districts were unconstitutional because the state intentionally drew the districts to benefit minorities and lacked any compelling state interest. See Miller v. Johnson, 115 S. Ct. 2475 (1995). As a result, the state is currently revising its districts. Similar 
California, Florida, Illinois, New York, and Texas. ${ }^{217}$ Thus, at least eighteen states satisfy the first Gingles criterion. ${ }^{218}$

Considering the proportional system as a possible remedy requires a redefinition of the first Gingles factor. To have the clear ability to elect a candidate of choice as a presidential elector under a proportional system, a minority group's proportion of a given state's voting-age population would have to be greater than or equal to the total voting-age population divided by the number of votes that state casts in the electoral college. ${ }^{219}$ Nineteen states meet this criterion with respect to African-Americans: the eighteen states previously identified, plus Missouri. ${ }^{220}$ Eight states meet the criterion with respect to Hispanics: the five with majority-Hispanic congressional districts, plus Arizona, New Jersey, and New Mexico. ${ }^{221}$

All together, then, a total of twenty-one states potentially satisfy the first Gingles factor. Perhaps more significant than the number of states is the number of electoral votes that these states represent: a grand total of 361 -more than two-thirds of the 538 votes cast. A successful $\S 2$ challenge to the winner-take-all system would thus have the potential to alter dramatically the way in which Presidents are chosen.

challenges are currently under way in several other states. Thus, many of these states may ultimately have fewer majority-minority districts than it would otherwise be possible to draw. However, so long as each of these states retains at least one such district, they will automatically satisfy the first Gingles criterion.

217. CONGRESSIONAL DISTRICTS IN THE 1990s, supra note 216 , at 57-58, 166, 234, 496-97, 703.

218. These states also clearly satisfy the first Gingles factor under the traditional formulation. If it is possible to draw a majority-minority district in an electoral scheme with $N$ House districts, it is also possible to draw a majority-minority district in an electoral scheme with $N+2$ presidential-elector districts.

219. This formulation actually requires a larger statewide minority population than the traditional Gingles formulation. Under the traditional formulation, a group need only be large enough to constitute a majority in a single-member district. Theoretically, in a state of 1000 voters with 10 seats to be filled, a district containing 51 minority voters, or $5.1 \%$ of the population, would be sufficient to satisfy the traditional Gingles criterion. Under the proportional formulation, the minority group would need to make up at least $10 \%$ of the population to be assured of gaining an elector, although it might be possible for a smaller group to choose an elector under certain circumstances.

The difference between these two formulations is minimized, however, by the Court's recent gloss on the first Gingles factor in Johnson v. De Grandy, 114 S. Ct. 2647 (1994). In De Grandy, the Court held that $\$ 2$ does not require states to draw the maximum possible number of majority-minority districts. Id. at $2659-60$. Instead, it usually only requires them to draw a number of majority-minority districts that is roughly proportional to the number of members of the minority group in the relevant population. Id. at 2658 \& n.1 I, 2660-63 (upholding redistricting plans that achieved substantial proportionality, but rejecting rule that proportionality of plan automatically grants state a "safe harbor"); see also id. at 2664 (O'Connor, J., concurring) ("[P]roportionality . . . is always relevant evidence in determining vote dilution, but is never itself dispositive. Lack of proportionality is probative evidence of vote dilution.").

220. CONGRESSIONAL DISTRICTS IN THE 1990s, supra note 216 , at 425 .

221. Arizona, New Jersey, and New Mexico would also probably satisfy the traditional formulation of the first Gingles factor. Although none of them has a majority-minority House district, each of them has at least one substantial minority-influence district. Arizona has a $44.8 \%$ Hispanic district; Missouri has a 48.0\% African-American district; and each of New Mexico's three districts are roughly one-third Hispanic. CONGRESSIONAL DISTRICTS IN THE 1990s, supra note 216 , at $35,425,487$. It is thus very likely that one could draw a pure single-member-district presidential-elector scheme with at least one majority-minority district in each of these states. Because it is unlikely that any state would want to implement a pure singlemember-district scheme, the proportional formulation makes more sense. 


\section{Political Cohesion}

The political-cohesion prong of Gingles is satisfied by a showing that "a significant number of minority group members usually vote for the same candidates." 222 Thus, the political-cohesion inquiry focuses primarily on the voting behavior of the minority group, rather than on the differences between minority and majority voters. Although other factors may be relevant, such as evidence of shared socioeconomic characteristics and efforts to engage in concerted political activity, the most important data for determining whether a minority group is cohesive are the results of past elections. Typically, a showing that at least $60 \%$ of minority voters support the same candidate establishes cohesion for the purposes of the Gingles inquiry. ${ }^{223}$

Courts have generally held that the most probative elections for the purposes of the Gingles analysis are contests involving viable minority candidates. ${ }^{224}$ Similarly, elections for the office that is the subject of the litigation ("endogenous" elections, to use the term that courts frequently employ) are considered somewhat more probative than contests involving other offices ("exogenous" elections). ${ }^{225}$ Additionally, the Supreme Court held in Gingles that "the fact that statistics from only one or a few elections are available for examination does not foreclose a vote dilution claim." 226 In jurisdictions with very few endogenous elections involving minority candidates, courts have attached significant probative value to the results of exogenous elections. ${ }^{227}$ Moreover, the $\S 2$ analysis does not necessarily presume that a candidate must be a member of a minority group in order to be a minoritypreferred candidate. Consequently, elections involving only white candidates may also have significant probative weight, if the plaintiffs can establish that a white candidate is truly the minority group's representative of choice. ${ }^{228}$

222. Thornburg v. Gingles, 478 U.S. 30, 56 (1986). The Court's opinion does not intimate that analysis of voting patterns is the only way of demonstrating cohesiveness. Instead, it describes it as "one way." Id.

223. Allan J. Lichtman \& J. Gerald Hebert, A General Theory of Vote Dilution, 6 LA RAZA L.J. 1, 5 (1993) (noting that, based on American political history, $60 \%$ margin of support in two-way race represents victory of "landslide proportions").

224. See, e.g., Jenkins v. Red Clay Consol. Sch. Dist. Bd. of Educ., 4 F.3d 1103, 1128 (3d Cir. 1993) ("As a general matter ... elections involving white candidates only are much less probative of racially polarized voting than elections involving both black and white candidates."), cert. denied, $114 \mathrm{~S}$. Ct. 2779 (1994); Citizens for a Better Gretna v. City of Gretna, 834 F.2d 496, 503 (5th Cir. 1987) ("[W]e conclude that Gingles is properly interpreted to hold that the race of the candidate is in general of less significance than the race of the voter-but only within the context of an election that offers voters the choice of supporting a viable minority candidate."), cert. denied, 492 U.S. 905 (1989).

225. Magnolia Bar Ass'n v. Lee, 994 F.2d 1143, 1149 (5th Cir.), cert. denied sub nom. Magnolia Bar Ass'n v. Hawkins, 114 S. Ct. 555 (1993).

226. Gingles, 478 U.S. at 57 n.25.

227. See Rangel v. Morales, 8 F.3d 242, 246-47 (5th Cir. 1993); Westwego Citizens for Better Gov't v. City of Westwego, 872 F.2d 1201, 1208-10 (5th Cir. 1939); Citizens for a Better Gretna, 834 F.2d at 502-03.

228. See Jenkins, 4 F.3d at 1125 (noting that "there may be majority candidates who truly may be the minority community's representative of choice"); Sanchez v. Bond, 875 F.2d 1488, 1494-95 (10th Cir. 1989), cert denied, 498 U.S. 937 (1990); City of Carrollton Branch of the NAACP v. Stallings, 829 F.2d 
How do courts determine the level of support among minority voters for particular candidates? In Gingles, the Court relied on two basic statistical techniques for measuring both political cohesion and racial bloc voting: homogenous-precinct analysis (also known as extreme-case analysis) and bivariate ecological regression analysis. ${ }^{229}$ These two techniques are now standard features of $\S 2$ cases. ${ }^{230}$ Homogeneous-precinct analysis involves examining voting precincts that are almost entirely composed of voters from one race. The total vote for a particular candidate in such a precinct is taken to offer a rough estimate of how voters of that race cast their ballots. Of course, it is quite possible that voters in racially mixed precincts have different preferences from those in homogenous precincts. ${ }^{231}$

Ecological regression analysis avoids this problem by examining all voting precincts. A helpful way to visualize this process is to picture a scatterdiagram, in which each precinct is represented by a point on a graph. ${ }^{232}$ The $\mathrm{X}$-axis of the graph measures the percentage of minority voters in that precinct, and the $\mathrm{Y}$-axis represents the percentage of voters in the precinct who voted for a particular candidate. If a high correlation exists between race and voter preference, the various precincts will be closely clustered about a line, as the districts with higher proportions of minorities will yield higher numbers in favor of the candidate. By running a regression analysis, one can determine the slope of that line, and the point at which it intercepts the Y-axis. ${ }^{233}$ From this information, it is possible to estimate the proportion of minority voters who voted for a particular candidate..$^{234}$

In the context of presidential elections, however, another very powerful source of information about voting behavior is available. Newspapers and television networks conduct extensive exit polls of voters throughout the nation. In these surveys, investigators ask a random sample of voters to fill out a questionnaire as they leave the polls. The questionnaire asks voters about basic demographic information, such as age, sex, race, and party affiliation, as well as how they voted in major elections. The responses are then weighted to take account of differences in the probability that a particular respondent will be selected. For example, if only 500 people vote at one polling location, and

1547, 1557 (11th Cir. 1987) (adopting Justice Brennan's assertion in Gingles that "[u]nder Section 2, it is the status of the candidate as the chosen representative of a particular racial group, not the race of the candidate that is important"), cert. denied, 485 U.S. 936 (1988).

229. For a detailed description of these methods and their use in the racially polarized voting inquiry, see GROFMAN ET AL., supra note 118, at 82-108.

230. See, e.g., id. at 74. Grofman, who has written and edited several books on techniques for measuring vote dilution, was the principal expert witness in Gingles. See 478 U.S. at 52-53.

231. GROFMAN ET AL., supra note 118, at 89.

232. See id. at 91 ("There is no substitute for careful visual inspection of the data in graphical form, that is, a plot of votes for the minority candidates against percentage minority in the precinct.").

233. The regression analysis also produces a comelation coefficient, which measures how good a "fit" exists between the hypothetical line and the observed data points.

234. The formula for these calculations is given in GROFMAN ET AL, supra note 118, at 86-90. 
1000 people vote at another, the likelihood that any particular respondent will be selected at the first site is twice as great as the likelihood that a particular respondent will be selected at the second. This imbalance can be corrected by assigning a response at the second site twice the weight of a response at the first. The accuracy of such polls depends on the sampling method used and on the size of the sample. ${ }^{235}$

When presented with relevant exit poll data, courts have shown no reluctance to rely on them in the Gingles analysis. ${ }^{236}$ Courts have indicated, in fact, that such data, when available, are a reliable and perhaps superior indicator of the degree of minority political cohesion and racially polarized voting. ${ }^{237}$ Unfortunately, such data are rarely available for state and local elections. ${ }^{238}$ Properly used, however, exit poll data can yield valuable insights into a jurisdiction's voting patterns-patterns that, at the very least, are strongly suggestive of the results that the more traditional forms of analysis might reveal.

Elections for the position of presidential elector are unusual in one very important respect. In nearly all of the states, the names of candidates for presidential elector are not listed on the ballot. The overwhelming majority of voters neither know nor care who those candidates are. In the context of presidential elections, then, the relevant criterion is not the identity of the candidates for the office of presidential elector, but the candidates for the office of President. The post-Gingles case law thus suggests that the most probative recent elections to examine are the 1984 and 1988 Democratic presidential primaries, in which an African-American candidate, Jesse Jackson, staged prominent campaigns for his party's nomination. There has never been a viable minority candidate for President in a general election. Data from the

235. See generally WAYNE C. CURTIS, STATISTICAL CONCEPTS FOR ATTORNEYS: A REFERENCE GUIDE 93-96 (1983) (discussing effects of "systematic sampling," "stratified random sampling," and "cluster sampling" on poll results); GARY T. HENRY, PRACTICAL SAMIPLING 34-46 (1990) (noting potential sources of error in sampling design).

236. See Hall v. Holder, 955 F.2d 1563, 1571 \& nn.14-15 (11th Cir. 1992) (relying in part on exit poll data to reach conclusion that county experienced racially polarized voting, and noting that regression analysis figures were nearly identical to exit poll results), rev'd on other grounds, 114 S. Ct. 2581 (1994); Romero v. City of Pomona, 883 F.2d 1418, 1426-27 (9th Cir. 1989) (relying on exit poll from city council primary election to conclude that district court had adequate basis to conclude that blacks and Hispanics were not cohesive as single group); DeBaca v. County of San Diego, 794 F. Supp. 990,999 (S.D. Cal. 1992) (relying on exit polls from 1988 presidential primary to conclude that blacks and Hispanics were not cohesive as single group), aff'd, 5 F.3d 535 (9th Cir. 1993).

237. See Chisom v. Roemer, No. 86-4057, 1989 U.S. Dist. LEXIS 108I6, at *14-15 (E.D. La. Sept. 13, 1989) ("In analyzing statistical data, the Court finds that the best available data for estimating the voting behavior of various groups in the electorate would come from exit polls . . . but such evidence is not available."), remanded, 917 F.2d 187 (5th Cir. 1990), rev'd on other grounds, 501 U.S. 380 (1991); Monroe v. City of Woodville, 688 F. Supp. 255, 258 (S.D. Miss. 1988) ("The best data would have been actual turn-out data as might have been collected by exit polls. This data was non-existent."), aff'd, 881 F.2d 1327 (5th Cir. 1989), vacated on other grounds, 493 U.S. 915 (1989), modified, 897 F.2d 763 (5th Cir. 1990), cert. denied, 498 U.S. 822 (1990).

238. See GROFMAN ET AL., supra note 118 , at $84 \&$ n.6 (noting that relevant survey data is usually only available in presidential or statewide contests). 
general elections, however, should also be significant, provided that it provides some adequate basis for demonstrating that a particular candidate is the minority community's representative of choice. In addition, data from exogenous elections, such as gubernatorial or senatorial contests involving minority candidates, should be significant.

What do the presidential election exit polls tell us about minority political cohesion? As noted in the introduction, exit polls from presidential elections show that an overwhelming majority of African-American voters-ranging from $82 \%$ to $90 \%$ - have preferred Democratic presidential candidates over the last twenty years. By contrast, the majority of white voters nationally have voted Republican during this same period. In the past three elections, white voters have preferred George Bush to Bill Clinton by a margin of $41 \%$ to $39 \%$, Bush to Michael Dukakis by a margin of 59\% to $40 \%$, and Ronald Reagan to Walter Mondale by a margin of $64 \%$ to $35 \% .{ }^{239}$ As Section B of this part demonstrates, similar patterns hold true in many statewide polls.

Results from the 1988 and 1984 presidential primaries also demonstrate a high level of racial cohesion. In state after state in those races, AfricanAmerican candidate Jesse Jackson consistently outpolled his rivals for the Democratic nomination by overwhelming margins among African-American voters, frequently by as much as $90 \%{ }^{240}$ In 1988 , these margins were large enough to enable him to win primaries in several Southern states, as well as a caucus in the key Northern state of Michigan. ${ }^{241}$ But he did very poorly among white voters in nearly every state, rarely getting as much as $10 \%$ of the vote. ${ }^{242}$ Courts have often used these sorts of results as evidence of political cohesion in other elections. ${ }^{243}$ Viewed in conjunction with the consistent and overwhelming support of African-American voters for Democrats in the general election, they leave little doubt as to the political cohesiveness of African-American voters in presidential elections. ${ }^{244}$

239. See sources cited supra note 9.

240. For figures from specific states, see infra Section IV.B.

241. See, e.g., GERMOND \& WITCOVER, supra note 123, at 289, 299-300.

242. For figures from specific states, see infra Section IV.B.

243. See, e.g., Hall v. Holder, 955 F.2d 1563, 1571-73 (11th Cir. 1992) (basing finding of racially polarized voting and black political cohesion in part on showing that $60.8 \%$ of black voters supported Jackson in 1984 and more than 90\% supported him in 1988), rev'd on other grounds, $114 \mathrm{~S}$. Ct. 2581 (1994); Citizens for a Better Gretna v. City of Gretna, 834 F.2d 496. 502 n.15 (5th Cir. 1987) (finding black voter cohesion based in part on results of local exit poll showing more than $95 \%$ support among African-Americans for Jackson in 1984 election).

244. It is harder to generalize about the cohesiveness of Hispanic voters, since the demographic characteristics of these voters vary significantly from one region to the next. For example, Puerto Ricans in the Northeast and Mexicans in the Southwest tend to be liberal Democrats, while Cubans in Florida are generally conservative Republicans. 


\section{White Bloc Voting}

Proof of white bloc voting is perhaps the most complicated of the three Gingles factors. Like the political-cohesion prong, it requires a careful analysis of past voting patterns. ${ }^{245}$ The proper interpretation of these voting patterns, however, is currently the subject of much dispute among the courts. Courts all agree that, at a minimum, plaintiffs must show that white voters and minority voters tend to prefer different candidates, and that as a result minority voters are unable to elect their candidates of their choice. Still partially unresolved, however, is the question of whether plaintiffs must also undertake some investigation of the reasons why white voters reject minority-preferred candidates and prove that those reasons are somehow linked to race.

Under Gingles, the standard for legally significant white bloc voting is that "the white majority votes sufficiently as a bloc to enable it-in the absence of special circumstances, such as the minority candidate running unopposedusually to defeat the minority's preferred candidate." ${ }^{246}$ This much of Gingles is binding law, announced in a section of the opinion that commanded majority support, and twice reaffirmed by a unanimous Court. ${ }^{247}$

This standard is flexible and fact-intensive; the level of bloc voting necessary to satisfy the $\S 2$ threshold may vary significantly from one case to the next. ${ }^{248}$ The key element is that the majority must usually-not necessarily always-be able to defeat the minority's preferred candidate. Hence, the white bloc voting inquiry generally requires courts to examine a series of elections. The absence of legally significant racially polarized voting in particular elections does not necessarily mean that it is not present in others. ${ }^{249}$ Thus, the fact that minority voters are occasionally able to elect candidates of their choice does not necessarily preclude them from $\S 2$ relief. ${ }^{250}$ Evidence of sustained proportional representation of minority voters over a series of elections, however, demonstrates a lack of significant white bloc voting. ${ }^{251}$

One major section of Justice Brennan's opinion in Gingles dealing with the standard for legally significant white bloc voting was signed by only three

245. Thomburg v. Gingles, 478 U.S. 30, 56 (1986) ("[T]he question whether a given district experiences legally significant racially polarized voting requires discrete inquiries into minority and white voting practices.").

246. Id. at 51 (citations omitted).

247. See Voinovich v. Quilter, 113 S. Ct. 1149, 1157 (1993); Growe v. Emison, 113 S. Ct. 1075, 1084 (1993); see also Johnson v. De Grandy, 114 S. Ct. 2647, 2651 (1994).

248. Gingles, 478 U.S. at 55-56 ("[T]he degree of bloc voting which constitutes the threshold of legal significance will vary from district to district.").

249. Id. at 57.

250. Id.

251. Id. at 77 (Brennan, J.); see also id. at 101-02 (O'Connor, J., concurring in judgment) (agreeing with Justice Brennan's conclusion that no $\$ 2$ violation occurred in district with "sustained and virtually proportional minority electoral success"). 
other Justices, however. In that section, Justice Brennan expressed the view that, under the results test of $\S 2$, the reasons why white voters reject minoritypreferred candidates are legally irrelevant. In his view, what matters is simply evidence of a significant correlation between race and voting preference. ${ }^{252}$ Thus, evidence that voting patterns are motivated by racial animus is not required..$^{253}$ Similarly, in Justice Brennan's view, the race of a candidate is irrelevant to the white bloc voting inquiry. ${ }^{254}$

Justice O'Connor, joined by three other Justices, concurred in Justice Brennan's judgment, but expressed a somewhat different view of racially polarized voting. She agreed that, under amended $\S 2$, plaintiffs need not demonstrate that a particular jurisdiction adopted or maintained a political system with any intent to discriminate. ${ }^{255}$ She expressed some reservations, however, as to whether the statute's emphasis on results implies that evidence concerning the causes of voter behavior is irrelevant:

Insofar as statistical evidence of divergent racial voting patterns is admitted solely to establish that the minority group is politically cohesive and to assess its prospects for electoral success, I agree that defendants cannot rebut this showing by offering evidence that the divergent racial voting patterns may be explained in part by causes other than race .... I do not agree, however, that such evidence can never affect the overall vote dilution inquiry. Evidence that a candidate preferred by the minority group in a particular election was rejected by white voters for reasons other than those which made that candidate the preferred choice of the minority group would seem clearly relevant in answering the question whether bloc voting by white voters will consistently defeat minority candidates. Such evidence would suggest that another candidate, equally preferred by the minority group, might be able to attract greater white support in future elections. ${ }^{256}$

Justice O'Connor's analysis thus suggests that legally cognizable vote dilution occurs only when white voters reject a candidate because of race. To pick a realistic example, suppose that African-American voters overwhelmingly preferred Jesse Jackson for a particular office, but that white voters consistently voted against him. Justice O'Connor's model of vote dilution would then ask whether white voters rejected Jackson because of his race, or

252. Id. at 63 (" $[\mathrm{W}]$ e reject [the] argument that racially polarized voting refers to voting patterns that are in some way caused by race, rather than to voting patterns that are merely correlated with the race of. the voter....").

253. Id. at $70-73$.

254. Id. at 68 (Brennan, J., with three Justices concurring) ("Under $\$ 2$, it is the status of the candidate as the chosen representative of a particular racial group, not the race of the candidate, that is important.").

255. See id. at 83 (O'Connor, J., concurring in judgment) ("Amended $\$ 2$ is intended to codify the 'results' test ... . and to reject the 'intent' test ....."); id. at 43-44.

256. Id. at 100 (O'Connor, J., concurring in judgment). 
whether some other factor, such as his lack of political experience, was the decisive factor. If the latter were the case, then another candidate-Colin Powell, for example-might fare equally well among African-American and white voters. $^{257}$ Thus, Justice O'Connor's opinion clearly suggests that courts may have to undertake some inquiry into the reasons why different racial groups have different voting preferences. The precise scope of this inquiry is unclear, however.

Several interpretations of Justice O'Connor's language are possible. The most extreme interpretation-one that, thus far, no court has adopted-would be that minority plaintiffs must affirmatively prove that their candidate's defeat at the polls was "on account of race or color," that is, that white voters reject the minority-preferred candidate for reasons related to race. ${ }^{258}$ There is an important methodological corollary to this position. Under Justice Brennan's analysis, plaintiffs may prove white bloc voting by a bivariate ecological regression analysis of the sort discussed above. The extreme interpretation of Justice O'Connor's position, in contrast, would require plaintiffs to perform a multivariate regression analysis, examining the correlation between voter preference and other factors in addition to race. ${ }^{259}$

Thus far, however, courts have almost uniformly relied on bivariate regression analysis to demonstrate vote dilution. Justice Brennan's opinion in Gingles remains the predominant analytical framework for evaluating white bloc voting. Nevertheless, both the Fifth and the Eleventh Circuits have shown signs recently that they are moving toward a vote-dilution standard based on slightly less extreme interpretations of Justice O'Connor's language. A minority of the Eleventh Circuit recently argued that plaintiffs may make out a prima facie case of vote dilution merely by showing significant disparities in voting patterns, but that defendants can rebut that showing by demonstrating that racial animus is not responsible for the defeat of minority-preferred candidates. ${ }^{260}$ This position is directly contrary to Justice Brennan's

257. It should be noted, however, that Colin Powell's experience in elective office is precisely the same as Jesse Jackson's. Neither man has any.

258. This view was advocated by the defendants in Gingles, and rejected by Justice Brennan. Gingles, 478 U.S. at 62 n.31 (Brennan, J., with three Justices concurring).

259. As a minority of the Fifth Circuit has noted, this approach is problematic from a social science perspective. Although a regression analysis can identify a correlation between race and other variables, on one hand, and voter preference, on the other, it cannot determine whether that correlation results from a causal relationship. See League of United Latin Am. Citizens v. Clements, 999 F.2d 831, 907-09 (5th Cir. 1993) (King, J., dissenting).

260. See Nipper v. Smith, 39 F.3d 1494, 1513 (11th Cir. 1994) (Tjoflat, C.J.) ("A defendant in a vote dilution case may always attempt to rebut the plaintiff's claim by introducing evidence of objective, nonracial factors under the totality of the circumstances standard."), cert. denied, 115 S. Ct. 1795 (1995); Solomon v. Liberty County, 899 F.2d 1012, 1022 (11th Cir. 1990) (en banc) (Tjoflat. C.J., specially concurring) ("[I]f a section 2 defendant can affirmatively show. under the totality of the circumstances, that the community is not motivated by racial bias in its voting, a case of vote dilution has not been made out.").

Defendants have attempted to introduce the results of multivariate analysis to rebut evidence of racially polarized voting in several cases. Most of these efforts have been unsuccessful. See, e.g., Romero 
conclusion in Gingles that "defendants may not rebut [plaintiffs'] case with evidence of causation or intent."

The leading case that holds expressly that proof of disparities in voting patterns is not sufficient to demonstrate legally significant white bloc voting comes from the Fifth Circuit. In League of United Latin American Citizens $v$. Clements (LULAC), ${ }^{262}$ an en banc court overturned a finding of vote dilution in judicial elections in several Texas counties, notwithstanding significant disparities between the preferences of minority voters and white voters. It concluded that "the evidence in most instances unmistakably shows that divergent voting patterns among white and minority voters are best explained by partisan affiliation," not race. ${ }^{263}$ The LULAC court carefully stopped short of holding that plaintiffs must demonstrate that their inability to elect candidates is the result of racial animus. ${ }^{264}$ Nor did it explain whether it was placing a new burden on the plaintiffs, or simply allowing defendants to rebut their showing of racial disparities with evidence of partisan influence. ${ }^{265}$ $L U L A C$ appears to hold, however, that plaintiffs in $\S 2$ cases must be prepared to prove, either directly or in rebuttal, that minority-preferred candidates do not lose elections primarily as a result of partisan preferences-or, if they do, that party affiliation is a mere "proxy" for race. ${ }^{266}$ Thus far no other circuit has endorsed this analysis. ${ }^{267}$

At a minimum, then, minority plaintiffs challenging the winner-take-all feature of the electoral system must demonstrate that white voters and minority voters tend to have different preferences. They must also demonstrate that as a result of this disparity, minority voters are usually-but not necessarily

v. City of Pomona, 665 F. Supp. 853, 859-60 (C.D. Cal. 1987) (rejecting validity of multivariate analysis), aff'd, 883 F.2d 1418 (9th Cir. 1989); see also GrofMAN ET AL., supra note 118, at 75 (noting that "lower courts have thus far concluded that a regression analysis that considers explanatory factors other than race is irrelevant to a Section 2 vote dilution claim"). But see Sanchez v. Colorado, 861 F. Supp. 1516, 1527

(D. Colo. 1994) (accepting multivariate analysis as rebuttal evidence).

261. Gingles, 478 U.S. at 74 (Brennan, J.).

262. 999 F.2d 831 (5th Cir. 1993) (en banc), cert. denied, 114 S. Ct. 878 (1994).

263. Id. at 861 .

264. See id. at 859 ("We need not hold that plaintiffs must supply conclusive proof that a minority group's failure to elect representatives of its choice is caused by racial animus in the white electorate ....").

265. See id. at 860 ("[W] need not resolve the debate today. Whether or not the burden of plaintiffs to prove bloc voting includes the burden to explain partisan influence, the result is the same.").

266. See id. (noting that "even partisan affiliation may serve as a proxy for illegitimate racial considerations").

267. Chief Judge Tjoflat's opinion in Nipper adopts a similar analysis, and cites $L U L A C$ with approval. See 39 F.3d at 1524-25 (holding that defendants may rebut showing of disparities in voting behavior with evidence of causation in totality-of-the-circumstances inquiry). However, that section of the en banc opinion was not joined by the four concurring judges. See id. at 1547 (Edmonson, J., concurring in part and concurring in result) (concurring in part of Chief Judge Tjoflat's opinion, but expressing no opinion as to whether the remainder is correct, arguing that conclusions reached in that section were not essential to deciding case). 
always-unable to elect candidates of their choice to the office of presidential elector. Under the holding of LULAC, they may also be required to show that the disparities in voting behavior are not simply the result of partisan affiliation. Again, however, it should be noted that $L U L A C$ remains something of an outlier in $\S 2$ caselaw, and that the prevailing mode of analysis is that employed by Justice Brennan in Gingles.

The exit poll results cited in the previous discussion clearly establish that, at least at the national level, white voters do tend to have substantially different preferences from minority voters. These figures strongly suggest, in fact, that many states are experiencing legally significant white bloc voting in presidential elections. Accordingly, the remainder of this subsection will examine whether partisan affiliations can adequately explain these disparities. The extent of racially polarized voting in specific states will then be considered in Section B.

As a preliminary matter, it is worth noting that it would be extremely anomalous for a court to find that a pattern of disparities in presidential voting could be better explained by partisan preferences than by race. Indeed, one of the dominant trends in presidential politics of the past half century has been the decline of political party influence. Presidential campaigns are increasingly marked by what political scientist Martin P. Wattenberg and others have termed "candidate-centered politics," emphasizing a candidate's character and record rather than party affiliation. ${ }^{268}$

One symptom of this decline in party influence has been a decrease in the number of people who strongly identify with one political party or the other, and a corresponding rise in the number of people who consider themselves independents. ${ }^{269} \mathrm{~A} 1990$ Gallup poll showed that some $30 \%$ of respondents identified themselves as independents, compared to $39 \%$ who considered themselves Democrats and $31 \%$ who considered themselves Republicans. ${ }^{270}$ A 1992 study revealed a continuation of this trend, with nonpartisans outnumbering both major political parties for the first time: $38 \%$ independent, $36 \%$ Democrat, and 25\% Republican. ${ }^{271}$ Another symptom of waning party allegiances is the increasing practice of "split ticket" voting. ${ }^{272}$ In 1952 , only $12 \%$ of voters cast a ballot for a presidential candidate of a different party than

268. See Martin P. Wattengerg, The Rise of Candidate-Centered Politics: Presidential ELECTIONS OF THE 1980S (1991).

269. HaROLD W. STANLEY \& RICHARD G. Niemi, Vital Statistics ON AMERICAN Politics 159-60 (3d ed. 1992).

270. Id. at 161 .

271. WATTENBERG, supra note 139 , at 173.

272. See id. at 17-23, 177-78; Amar \& Amar, supra note 40, at 915-16. 
their choice for the House of Representatives. By 1992, that number had climbed to $36 \%{ }^{273}$ Perhaps the most significant indicator of the decline in the importance of parties, however, is the success in the 1992 election of independent candidate Ross Perot. Despite his lack of an established campaign organization and his avoidance of traditional campaign methods, Perot received $19 \%$ of the national vote - the best popular vote showing by any third-party candidate since Theodore Roosevelt in 1916. ${ }^{274}$

I do not mean to suggest that parties are irrelevant to contemporary American political behavior. Indeed, partisan affiliation remains one of the best predictors of individual voting behavior. ${ }^{275}$ This should not be surprising, because individuals define their partisan identification on the basis of which candidates they tend to favor. Rather, I am suggesting that, at least at the national level, political parties are much less influential now than at any time in recent history. At the same time, exit polls from the past three elections indicate that racial polarization in voting has remained quite constant.

Indeed, at the national level, race and party identification appear to be inextricably intertwined. In the 1992 presidential election, nearly $69 \%$ of black voters surveyed in a national exit poll identified themselves as Democrats, compared with only $7 \%$ who identified themselves as Republicans. ${ }^{276}$ As discussed in Part II, the gap between black and white voters in terms of party identification is no accident. Instead, it is in large part due to the positions that the two major parties have taken on racial issues as a result of their efforts to secure the Southern electoral vote.

Furthermore, data from the past three elections demonstrate that significant racial disparities exist even among voters of the same party. Regardless of their partisan identification, white voters in these elections have been much more likely to support the Republican candidate for President, while black voters

273. WATTENBERG, supra note 139, at 174; see also Richard E. Cohen, What Coattails, 25 NAT'L J. 1285 (1993) (noting that 99 of 435 House districts in 1992 elected Representative from one party and voted for candidate of other party for President).

274. WATTENBERG, supra note 139 , at 170 .

275. Id. at 7.

276. My calculations are based on data contained in VOTER RESEARCH \& SURVEYS, GENERAL ELECTION EXIT POLLS, 1992 (2d ed. 1993) [hereinafter GENERAL ELECTION ExIT POLL 1992] (surveying 1539 black voters). This exit poll is available as a computer file from the Inter-University Consortium for Political and Social Research, Ann Arbor, Michigan. 
have been more likely to support the Democratic candidate. Data from three polls are summarized in the following table:

\begin{tabular}{||l|l|c|c|c|c|c|c||}
\hline \multicolumn{2}{|c|}{} & \multicolumn{2}{|c|}{ Democrats } & \multicolumn{2}{c|}{ Republicans } & \multicolumn{2}{c|}{ Independents } \\
\cline { 2 - 8 } \multicolumn{2}{|c|}{} & White & Black & White & Black & White & Black \\
\hline \multirow{3}{*}{1984} & Walter Mondale & $69 \%$ & $95 \%$ & $6 \%$ & $43 \%$ & $33 \%$ & $78 \%$ \\
\cline { 2 - 8 } & Ronald Reagan & $30 \%$ & $3 \%$ & $93 \%$ & $51 \%$ & $67 \%$ & $18 \%$ \\
\hline \multirow{3}{*}{1988} & Michael Dukakis & $78 \%$ & $94 \%$ & $8 \%$ & $34 \%$ & $41 \%$ & $73 \%$ \\
\cline { 2 - 8 } & George Bush & $21 \%$ & $4 \%$ & $92 \%$ & $60 \%$ & $57 \%$ & $20 \%$ \\
\hline \multirow{3}{*}{1992} & Bill Clinton & $73 \%$ & $91 \%$ & $10 \%$ & $28 \%$ & $35 \%$ & $64 \%$ \\
\cline { 2 - 9 } & George Bush & $11 \%$ & $5 \%$ & $72 \%$ & $52 \%$ & $32 \%$ & $17 \%$ \\
\cline { 2 - 9 } & Ross Perot & $15 \%$ & $4 \%$ & $17 \%$ & $17 \%$ & $30 \%$ & $18 \%$ \\
\hline
\end{tabular}

TABLE 1. National Election Results by Race ${ }^{277}$

As Table 1 indicates, the majority of both Democratic and Republican voters, regardless of their race, do tend to support their party's nominee. The level of crossover voting in both major parties, however, differs markedly according to race. Black Democrats have remained overwhelmingly loyal to their party's nominees, while anywhere from $21 \%$ to $30 \%$ of white Democrats have been willing to cross party lines. Similarly, white Republicans have shown a high degree of loyalty to their party and, in the case of the 1992 election, a strong aversion to voting for Democrats. In each election, however, black Republicans have shown a strong inclination to cross party lines to vote for the Democratic nominee. Since these racial disparities occur within political parties, they cannot be explained on partisan grounds.

Even among independent voters, similar patterns hold true. The common thread among independents is that they do not identify themselves with any political party, even though as individuals they may have distinct political preferences. One might therefore expect not to see significant differences in voting behavior between black and white independent voters. Even among

277. Id. (surveying 4350 white Democrats, 1086 black Democrats, 4377 white Republicans, 100 black Republicans, 3637 white independents, and 236 black independents); CBS NEWS/NEW YORK TIMES, GENERAL ELECTION EXIT POLL: NATIONAL FILE, 1988 [hereinafter CBS NEWS EXIT POLL 1988] (surveying 3052 white Democrats, 1067 black Democrats, 3339 white Republicans, 100 black Republicans, 2565 white independents, and 189 black independents); CBS NEwS/NEw YORK TiMES. ELECTION SURVEY, 1984: EleCtion DaY National SuRvey (3d ed. 1986) [hereinafter CBS NEwS Exit Poll 1984] (surveying 2532 white Democrats, 874 black Democrats, 2987 white Republicans, 71 black Republicans, 2148 white independents, and 160 black independents).

My calculations are based on data contained in these three exit polls, which are available as computer files from the Inter-University Consortium for Political and Social Research, Ann Arbor, Michigan. 
independents, however, such differences do exist. Black voters who identify themselves as independents have voted overwhelmingly for Democratic presidential candidates, while strong majorities of white independents voted Republican in both 1984 and 1988. In 1992, when the vote of white independents was split among three candidates, black independents were almost twice as likely as their white counterparts to vote for Bill Clinton. Again, it is impossible to explain these disparities on partisan grounds, since independents, by definition, do not identify with any political party.

Thus, while party identification appears to be a fairly good predictor of voter preference, it cannot fully explain the consistent pattern of disparities between black and white voter preferences in modern presidential elections. Moreover, these statistics must be viewed in light of the fact that none of these elections involved a viable minority candidate. The results of the 1984 and 1988 presidential primaries, which revealed wide disparities between black and white voters in their support for Jesse Jackson, suggest that if an AfricanAmerican were in the general election, the pattern of racial polarization might be much more pronounced. White Democrats, for example, would have been even more likely to crossover to vote Republican in 1988 if Jackson had been their party's nominee. ${ }^{278}$ The results of those elections suggest that the disparities between white and black voters are in fact closely linked to race, and that, at the national level at least, voting in presidential elections is highly racially polarized. ${ }^{279}$

\section{The Totality of the Circumstances}

Proof of the three Gingles factors is not sufficient to establish $\S 2$ liability. Courts must also examine the totality of the circumstances to determine whether, in light of all the relevant facts, minority voters have an equal opportunity to participate in the political process. ${ }^{280}$ This inquiry can help to determine whether, beyond statistical disparities that seem to support a claim of vote dilution, a particular election practice shuts minorities out of the political process.

278. See infra text accompanying note 326 .

279. Because such analysis is, at present, legally irrelevant to the $\$ 2$ inquiry, this Article does not undertake any analysis of race in comparison to other factors that might influence voting preference, such as income level, age, or education. It is worth noting, however, that detailed multivariate studies of voting behavior in congressional and state legislative elections indicate that race is the factor that best explains the different levels of success enjoyed by white candidates and African-American candidates. See Richard Pildes, The Politics of Rage, 108 HARV. L. REV. 1359, 1369-70 (1995) (reviewing QUiET REVOLUTION. supra note 2) (citing published and unpublished studies).

280. Johnson v. De Grandy, 114 S. Ct. 2647, 2657-58 (1994); NAACP v. City of Niagara Falls, 65 F.3d 1002 (2d Cir. 1995) (upholding district court finding that plaintiffs failed to prove $\$ 2$ violation. despite their proof of all three Gingles factors). 
The totality-of-the-circumstances inquiry typically focuses on several factors that were enumerated in the Senate report accompanying the 1982 amendments to $\S 2$ :

1. the extent of any history of official discrimination in the state or political subdivision that touched the right of the members of the minority group to register, to vote, or otherwise to participate in the democratic process;

2. the extent to which voting in the elections of the state or political subdivision is racially polarized;

3. the extent to which the state or political subdivision has used unusually large election districts, majority vote requirements, antisingle-shot provisions, or other voting practices or procedures that may enhance the opportunity for discrimination against the minority group;

4. if there is a candidate slating process, whether the members of the minority group have been denied access to that process;

5 . the extent to which members of the minority group in the state or political subdivision bear the effects of discrimination in such areas as education, employment and health, which hinder their ability to participate effectively in the political process;

6. whether political campaigns have been characterized by overt or subtle racial appeals;

7. the extent to which members of the minority group have been elected to public office in the jurisdiction. ${ }^{281}$

The report identified two additional factors that may have some probative value: a lack of responsiveness on the part of elected officials to the "particularized needs" of minority voters and a "tenuous" justification for the policy underlying the challenged practice. ${ }^{282}$ These factors were initially derived from the Supreme Court's decision in White v. Regester ${ }^{283}$ and the subsequent decision of the Fifth Circuit in Zimmer v. McKeithen. ${ }^{234}$

The totality-of-the-circumstances test occupies a somewhat nebulous position in the overall vote-dilution inquiry. Gingles makes it clear that, with the exception of those factors incorporated in the three-part threshold test, no particular combination of the Senate factors is essential to a plaintiff's case. ${ }^{285}$ Yet the Supreme Court's recent decision in De Grandy v. Johnson makes it equally clear that courts cannot find vote dilution under $\S 2$ without some consideration of the totality of the circumstances. ${ }^{286}$ Courts have generally recognized, however, that "it [will] be a highly unusual case in which

281. S. REP. No. 417 , supra note 135 , at $28-29$.

282. Id. at 29.

283. 412 U.S. 755 (1973).

284. 485 F.2d 1297 (5th Cir. 1973), aff'd sub nom. East Carroll Parish Sch. Bd. v. Marshall, 424 U.S. 636 (1976).

285. See Thomburg v. Gingles, 478 U.S. 30, 48-51 (1986).

286. See 114 S. Ct. 2647, 2657 (1994). 
a plaintiff successfully prove[s] the existence of the three Gingles factors and still fail[s] to establish a violation [of § 2]."287

Whatever role the Senate factors play in the overall inquiry, it seems clear that several of these elements are present in modern-day presidential elections. First, as noted in Part II, presidential elections in the United States during the last fifty years have repeatedly been marked by both overt and subtle racial appeals, including three clear attempts to manipulate the electoral college machinery to further an explicitly racist agenda. Although these efforts focused on the South, their effects have been felt throughout the nation. Second, no member of a minority group has ever been elected President or Vice President, or won the nomination of a major party for either position. The one candidate who has staged a credible run for a major party nomination, Jesse Jackson, floundered due to his inability to attract the support of white voters. ${ }^{288}$ Third, minority citizens throughout the country "bear the effects of discrimination" in many walks of life, including education, employment, health, and housing. These persistent inequalities clearly have the potential to hinder minority voters' ability to participate in the political process. Taken together, then, several of the Senate factors suggest that, given the totality of the circumstances, the winner-take-all system may operate to deprive minority voters of an equal opportunity to participate in the selection of the nation's Chief Executive.

One factor that could weigh against application of $\S 2$ to the electoral college under the totality-of-the-circumstances analysis is the legitimate interest of a state in maintaining the winner-take-all rule. Here again the Voting Rights Act case law regarding judicial elections provides an interesting analogy. In Houston Lawyers' Association v. Attorney General, ${ }^{289}$ the Supreme Court

287. Jenkins v. Red Clay Consol. Sch. Dist. Bd. of Educ., 4 F.3d 1103, 1116 n.6 (3d Cir. 1993), cert. denied, 114 S. Ct. 2779 (1994); accord NAACP v. City of Niagara Falls, 65 F.3d 1002 (2d Cir. 1995).

Niagara Falls apparently was such an unusual case. The Second Circuit held there that, although the plaintiffs had proved the three Gingles factors, the district court's determination that the totality of the circumstances did not demonstrate vote dilution was not clearly erroneous. However, the court noted its general agreement with the Third Circuit's observation in Jenkins. It also required that

[i]n such cases, the district court must explain with particularity why it has concluded . . . that

an electoral system that routinely results in white voters voting as a bloc to defeat the candidate of choice of a politically cohesive minority group is not violative of $\S 2$ of the Voting Rights Act.

Id. at 1019 n.2l.

288. Critics of this Article will no doubt point to General Colin Powell, whose firtation with a presidential bid is discussed above. See supra note 126 and accompanying text. Powell, however, has never run for any office, and has now decided not to run for President in 1996. See, e.g., Francis X. Clines, Powell Rules Out '96 Race; Cites Concerns for Family and His Lack of 'a Calling,' N.Y. TIMES, Nov. 9, 1995, at Al. It is certainly possible that, had Powell run, he would have been an attractive candidate to both white and black voters. That is by no means certain, however. See, e.g., Richard L. Berke, Powell Record is Criticized by Conservatives in GOP. N.Y. TIMES. Nov. 2, 1995, at A26.

Since no American, black or white, has ever cast a ballot for Powell, the strength of his candidacy remains a matter of pure conjecture. Political realities are often quite different from preliminary forecasts, and $\$ 2$ requires an analysis of historical fact, rather than hypothetical possibility.

289. S0I U.S. 419, 426-27 (1991). 
noted that a state might have a legitimate interest in maintaining a link between the area over which a judge exercised jurisdiction and the electoral base from which that judge was selected. Lower courts have since amplified this concept. In $L U L A C$, however, the Fifth Circuit rejected the argument that this "linkage" interest automatically precluded $\S 2$ liability, but decided nonetheless that Texas had a substantial interest in maintaining linkage and that plaintiffs could not override this interest without an equally substantial showing of legally significant vote dilution. ${ }^{290}$

In Nipper v. Smith, ${ }^{291}$ Chief Judge Tjoflat of the Eleventh Circuit took a somewhat different tack. He concluded that the state's linkage interest was of "little, if any" relevance to the totality-of-the-circumstances inquiry. ${ }^{292} \mathrm{He}$ joined the majority of the en banc panel, however, in concluding that the state's linkage interest precluded the court from granting relief under $\S 2$. The rationale for this decision was that the remedies proposed by the plaintiffs-including subdistricting and cumulative voting-would seriously undermine the administration of justice in the state. ${ }^{293}$

"Linkage," of course, is a concept that does not make any sense outside the context of judicial elections. Nonetheless, it is possible that states may have a related interest in preserving the winner-take-all feature of the electoral college. By casting their electoral votes in a bloc, states may arguably increase their political influence relative to other states and maximize the voting power of their individual citizens. This interest could conceivably be significant enough to preclude implementation of any alternate system.

This argument has several significant flaws, however. First, in states that experience significant vote dilution, use of the winner-take-all system does not increase the voting power of the citizenry. Rather, it increases the voting power of certain citizens, at the expense of others. In his mathematical analysis of the electoral college in the 1960s, John F. Banzhaf pointedly noted that he had not taken into account the dynamics of group behavior within states. ${ }^{294}$ Rather, he assumed that all citizens within a state had equal voting power. As the analysis in the next section suggests, however, in a state like Alabama, this assumption is false. Because of severely racially polarized voting, AfricanAmerican voters in Alabama have virtually no influence over the outcome of a statewide election.

Second, it is by no means clear that states necessarily increase their political influence relative to other states by maintaining the winner-take-all

290. 999 F.2d 831, 876 (5th Cir. 1993) (en banc), cert. denied, 114 S. Ct. 878 (1994) ("We hold that proof of dilution, considering the totality of the circumstances, must be substantial in order to overcome the state's interest in linkage established here.").

291. 39 F.2d 1494 (11th Cir. 1994).

292. Id. at 1542 (Tjoflat, C.J.). This portion of the Nipper opinion was not joined by the four concurring judges. See id. at 1547 (Edmondson, J., concurring).

293. Id. at 1546-47 (Edmondson, J., concurring).

294. Banzhaf, supra note 39 , at $304,308,328$. 
system. Quite the opposite may be true. If a state consistently tends to favor one major party or the other, under a winner-take-all rule, candidates from both parties may have an incentive to ignore that state.

In 1992, for example, the Florida legislature considered a bill that would have replaced the winner-take-all rule with a congressional-district system. ${ }^{295}$ Although one of the primary motives behind the bill was undoubtedly the desire of Democratic lawmakers to break the Republican party's apparent "lock" on Florida's electoral votes, supporters of the measure argued that it would increase the state's political influence and ability to compete for federal funds by giving both Democrats and Republicans an incentive to campaign in Florida. ${ }^{296}$ Republicans in the legislature ultimately managed to block the bill, which clearly ran counter to their party's interests. Thus, with respect to Florida, it seems quite possible that the continued dominance of the winnertake-all rule is the product of partisan maneuvering, rather than the result of any concrete benefits it produces for the state.

Furthermore, it is important to remember that the totality-of-thecircumstances analysis is a balancing test which, like the Gingles factors, may lead to different results in different jurisdictions. Ėven if a state could demonstrate a legitimate state interest in maintaining the winner-take-all rule, that interest should be weighed against other factors-most significantly, the degree to which race is a factor in campaigns and the ability of minority voters to choose presidential electors. In a jurisdiction in which minority voters are essentially denied any voice in the selection of the President, any policy justifications offered by the state will have a hollow ring.

\section{B. Some Specific Examples}

Presidential electors are chosen at the state level. As a result, the ability of minority voters to choose electors will necessarily vary from state to state. Hence the winner-take-all system may be illegal in some states and perfectly legal in others. ${ }^{297}$ The preceding section established both that several states contain enough minority voters to satisfy the first Gingles factor and that racial bloc voting and minority political cohesion are evident in nationwide voting patterns. This section examines patterns of racially polarized voting in a few selected states to determine whether they meet the $\S 2$ threshold for legally significant bloc voting.

295. See GLENNON, supra note 24 , at 12-13.

296. See, e.g., Electoral Reform: A Good Bill, ST. PETERSBURG Times, Mar. 2, 1992, at 10A.

297. See Thomburg v. Gingles, 478 U.S. 30,79 (1986) (requiring "intensely local" appraisal of challenged scheme). 


\section{Alabama}

The South's long history of discrimination against African-Americans in all walks of life suggests that the Southern states would be particularly vulnerable to a $\S 2$ challenge based on the use of the winner-take-all system. This subsection undertakes a $\S 2$ analysis of one state where racially polarized voting has been particularly severe: Alabama. ${ }^{298}$ For the purposes of this Article, Alabama provides a particularly interesting study because of the central role it played in Strom Thurmond's 1948 campaign, the 1960 freeelector movement, and George Wallace's 1968 campaign.

Alabama currently has seven congressional districts and therefore casts nine electoral votes in presidential elections. At the time of the 1990 census, the state had a voting-age population of $2,981,799$, of which $75.9 \%$ was nonHispanic white and $22.7 \%$ - slightly more than two-ninths-was AfricanAmerican. ${ }^{299}$ Six of the congressional districts have substantial white votingage majorities; the seventh has a $63.4 \%$ African-American voting-age majority. ${ }^{300}$ Thus, under a congressional-district scheme, African-American voters would have the clear ability to choose one of the state's nine presidential electors, while under a proportional scheme, they might be able to choose two of the nine. Under any of the formulations outlined above, Alabama therefore satisfies the first Gingles factor.

Furthermore, the evidence of racially polarized voting in Alabama is unmistakable. African-American voters exhibit a high degree of political cohesion, while white voters tend to vote sufficiently as a bloc to prevent African-Americans from choosing even a single presidential elector. In the 1984 Democratic primary, the African-American vote was split between Jesse Jackson and Walter Mondale. ${ }^{301}$ Jackson received approximately 50\% of the African-American vote, while Mondale received about $47 \%$. The white vote was split between Mondale, Senator John Glenn, and Senator Gary Hart. Hart received 37\% of the vote, Glenn received 32\%, and Mondale received $29 \%$. Jackson received less than $1 \%$ of the white vote. ${ }^{302}$ These figures clearly indicate a disparity between the preferences of African-American and white

298. For a detailed discussion of the history of vote-dilution litigation in Alabama and the persistence of racially polarized voting patterns there, see Peyton McCrary et al., Alabama, in QUIET REVOLUTION, supra note 2, at 38 .

299. THE Election Data BoOK: A Statistical Portrait of Voting IN AMERICA 1992, at 7 (Kimball W. Brace ed., 1993) [hereinafter ELECTION DATA BOOK].

300. Id. at 43.

301. Many Afiican-American political leaders had urged their constituents to support Mondale, rather than Jackson. See JACK W. GERMOND \& JULeS WITCOVER, WAKE US WHEN IT'S OVER: PRESIDENTIAL Politics of 1984, at 68-85 (1985); Bill Peterson \& Milton Coleman, Black Voters Back Jackson. Aid Mondale, WASH. POST, Mar. 14, 1984. at A1. A12.

302. My calculations are based on data contained in CBS NEwS/NEw YORK TIMES, PRIMARY ELECTION DAY EXIT POLLS, 1984 (1985) (computer file available from Inter-University Consortium for Political and Social Research, Ann Arbor, Mich.) [hereinafter CBS NEWS PRIMARY ELECTION EXIT POLLS 1984] (Alabama file) (surveying 704 white voters and 596 black voters). 
voters. Such a disparity is also evident in the results of the 1988 primary. In that race, Jackson received $96 \%$ of the African-American vote, but only $6 \%$ of the white vote. Among white voters, Tennessee Senator Al Gore was a clear favorite, with $64 \%$ of the vote. About $12 \%$ of whites voted for Michael Dukakis, and another $12 \%$ for Representative Richard Gephardt. ${ }^{303}$ Jackson's nearly unanimous support among African-American voters enabled him to win the state. ${ }^{304}$

Results from these primary elections are perhaps the most relevant to the vote-dilution inquiry because they were the only ones that offered AfricanAmerican voters an opportunity to support a viable African-American candidate. They suggest that black Democrats in Alabama are highly cohesive and that they have very different preferences from white Democrats. Data from the past three general elections confirm this impression. In all three elections, the Republican presidential candidate won the state despite near-unanimous black support for the Democratic candidate. The margins of support for the major party candidates by black and white voters in Alabama are summarized in the following table:

\begin{tabular}{||l|l|c|c||}
\hline \multicolumn{2}{|c|}{} & $\begin{array}{c}\text { White } \\
\text { Vote }\end{array}$ & $\begin{array}{c}\text { Black } \\
\text { Vote }\end{array}$ \\
\hline \multirow{3}{*}{1984} & Walter Mondale & $14 \%$ & $92 \%$ \\
\cline { 2 - 4 } & Ronald Reagan & $86 \%$ & $8 \%$ \\
\hline \multirow{3}{*}{1988} & Michael Dukakis & $34 \%$ & $89 \%$ \\
\cline { 2 - 4 } & George Bush & $64 \%$ & $11 \%$ \\
\hline & Bill Clinton & $30 \%$ & $91 \%$ \\
\cline { 2 - 4 } & George Bush & $56 \%$ & $3 \%$ \\
\cline { 2 - 4 } & Ross Perot & $12 \%$ & $4 \%$ \\
\hline \hline
\end{tabular}

TABLE 2. Alabama Election Results by Race $e^{305}$

303. My calculations are based on data contained in CBS NEwS/NEw YORK TIMES, SUPER TUESDAY PRIMARY ELECTION EXIT POLLS, 1988 (1989) (computer file available from Inter-University Consortium for Political and Social Research, Ann Arbor, Mich.) [hereinafter CBS NEwS SUPER TUESDAY ExIT POLLS 1988] (Alabama Democratic primary file) (surveying 835 white voters and 486 black voters).

304. Jackson also won the primaries in Georgia, Alabama, Louisiana, Mississippi, and Virginia, all with strong support from African-American voters. See, e.g., GERMOND \& WITCOVER, supra note 123, at 289.

305. My calculations are based on data contained in GENERAL ELECTION EXIT POLL 1992, supra note 276 (Alabama file) (surveying 597 white voters and 200 black voters); CBS NEws EXIT POLL 1988, supra note 277 (national file) (surveying 161 white voters and 41 black voters); CBS NEwS ExIT POLL 1984, supra note 277 (national file) (surveying 168 white voters and 117 black voters). 
These figures indicate a pattern of severely racially polarized voting, with nearly unanimous African-American support for Democratic candidates and extremely strong white support for Republican candidates. Moreover, under Gingles, the figures clearly indicate a legally significant level of white bloc voting. A large number of African-American voters tend to vote for the same candidate, and white voters vote sufficiently as a bloc to enable them consistently to defeat all of the minority's preferred candidates. ${ }^{306}$

It is worth pausing a moment to consider the implications of these figures. They demonstrate that, no matter how strong African-American support for a particular presidential candidate may be in Alabama, African-American voters have no opportunity to elect even a single presidential elector pledged to support that candidate. They also suggest that a candidate who hopes to win in Alabama has virtually no incentive to court black voters. Their votes simply do not figure in the selection of presidential electors. The overall effect is the same as it would be if the Alabama authorities simply took the presidential ballots of black voters and threw them into the trash heap.

Can this situation be dismissed as an unfortunate accident, a necessary consequence of majority rule? In Alabama, where state authorities for decades resorted to the most horrific forms of brutality to keep African-Americans from voting, such explanations are hard to swallow. They become even more suspect when one considers that three times in the past fifty years, Alabama electors have cast their ballots for overtly racist and segregationist candidates. Viewed in this context, the winner-take-all rule appears little different from literacy tests, the white primary, and the poll tax-nothing more nor less than an instrument of white supremacy.

\section{California}

In California, the evidence of racially polarized voting is clearly not as strong as it is in Alabama. Nonetheless, the available evidence strongly suggests that California meets all three of the Gingles conditions with respect to African-American voters. With respect to Hispanics, the state's largest minority group, the evidence is much less conclusive, although it provides some basis for a finding of vote dilution.

California is currently our nation's largest state, with fifty-four electoral votes-twenty-one more than its closest rival, New York-and it has been carried by the winning presidential candidate in every election since 1980. Like the South, California has a large African-American population. Unlike most of the Southern states, however, it also has significant Asian-American and

306. See Thomburg v. Gingles, 478 U.S. 30, 56 (1986) (discussing inquiries relevant to finding legally significant levels of racially polarized voting). 
Hispanic populations. ${ }^{307}$ According to the 1990 census, $61.2 \%$ of the state's VAP is non-Hispanic white, $6.7 \%$ is African-American, $8.9 \%$ is non-Hispanic Asian, and $22.5 \%$ is Hispanic. ${ }^{308}$ Of the state's fifty-two congressional districts, five have Hispanic voting-age majorities, and several others have large Hispanic influence blocs. ${ }^{309}$ None of the fifty-two has an AfricanAmerican or Asian-American voting-age majority. There are, however, four districts with large African-American influence blocs, ranging from $28.5 \%$ of the VAP to $41.9 \%$ of the VAP, ${ }^{310}$ and several districts have elected AfricanAmerican members of Congress.

It is thus clear that California satisfies the first Gingles factor with respect to Hispanics. It is somewhat less clear with respect to African-Americans or Asian-Americans, since the state has not actually drawn any majority-AfricanAmerican or majority-Asian-American districts. Nonetheless, it seems almost obvious that it would be possible to draw a majority-black district in either a fifty-two or a fifty-four member scheme, thereby satisfying the first Gingles factor in its traditional formulation. If one employs the alternative proportional formulation outlined above, California meets the first Gingles factor with respect to both Asian-Americans and African-Americans. Since the state has fifty-four electoral votes, a group only needs to constitute one fifty-fourth of the VAP, or about $1.9 \%$, in order to have the clear opportunity to choose one elector. Both minority groups easily meet this threshold.

Because no viable Hispanic or Asian-American candidate has run for President, it is difficult to draw accurate conclusions about the cohesiveness of these groups. African-Americans, however, exhibited strong political cohesion in both the 1984 and 1988 presidential primaries. In 1984, Jackson received $78 \%$ of the black vote, compared to only $9 \%$ of the white vote. ${ }^{311}$ In 1988 , he received $89 \%$ of the black vote and $14 \%$ of the white vote. ${ }^{312}$ These figures provide an ample basis for a finding of African-American political cohesion.

General election results again confirm the political cohesiveness of African-Americans in California and provide some basis for a finding of

307. The Hispanic population in California is largely comprised of Mexican-Americans, some of whom are non citizens and thus ineligible to vote. See CAL. CONST. art. II, § 2 (restricting right to vote to U.S. citizens).

308. ELECTION DATA BOOK, supra note 299 , at 7.

309. Id. at 113-14.

310. Id.

311. My calculations are based on data contained in CBS NEwS PRIMARY ELECTION EXIT POLLS 1984, supra note 302 (California file) (surveying 1768 white voters and 390 black voters).

312. My calculations are based on data contained in CBS NEWS/NEW YORK TIMES, PRIMARY ELECTION EXIT POLLS, 1988 (1989) (computer file available from Inter-University Consortium for Political and Social Research, Ann Arbor, Mich.) [hereinafter CBS NEWS PRIMARY ELECTION ExIT POLLS 1988] (Califomia file) (surveying 2274 white voters and 504 black voters). 
cohesiveness among Hispanic voters. The results of the past three elections are as follows:

\begin{tabular}{||l|l|c|c|c||}
\hline \hline \multicolumn{2}{||c|}{} & $\begin{array}{c}\text { White } \\
\text { Vote }\end{array}$ & $\begin{array}{c}\text { Black } \\
\text { Vote }\end{array}$ & $\begin{array}{c}\text { Hispanic } \\
\text { Vote }\end{array}$ \\
\hline \multirow{2}{*}{1984} & Walter Mondale & $35 \%$ & $80 \%$ & $63 \%$ \\
\cline { 2 - 5 } & Ronald Reagan & $64 \%$ & $16 \%$ & $37 \%$ \\
\hline \multirow{2}{*}{1988} & Michael Dukakis & $41 \%$ & $85 \%$ & $70 \%$ \\
\cline { 2 - 6 } & George Bush & $57 \%$ & $11 \%$ & $28 \%$ \\
\hline \multirow{3}{*}{1992} & Bill Clinton & $42 \%$ & $81 \%$ & $64 \%$ \\
\cline { 2 - 6 } & George Bush & $35 \%$ & $8 \%$ & $23 \%$ \\
\cline { 2 - 6 } & Ross Perot & $23 \%$ & $8 \%$ & $12 \%$ \\
\hline
\end{tabular}

TABLE 3. California Election Results by Race $e^{313}$

Although African-American support for the Democratic candidates is not quite as high as it is in Alabama, black voters in California remain overwhelmingly partial to the Democratic ticket. Hispanic voters also appear to be extremely loyal Democrats, but not to the same degree as black voters.

The third Gingles factor, white bloc voting, is more problematic. The results of the 1992 election indicate that, at least in certain circumstances, enough white voters will vote for the minority-preferred candidate to enable that candidate to win the state contest. Thus, in 1992, African-American voters did get to elect their candidates of choice as presidential electors.

Do the results of the 1992 election foreclose a finding of vote dilution in California? Under the prevailing $\S 2$ analysis, they clearly do not. Under Gingles and its progeny, the relevant inquiry in any $\S 2$ vote-dilution case is not what happened in any one election, but what usually happens. ${ }^{314}$ The inquiry does not look to isolated instances, but to patterns. Indeed, the Court specifically noted that "the success of a minority candidate in a particular

313. My calculations are based on data contained in GENERAL ELECTION EXIT POLL 1992, supra note 276 (California file) (surveying 1618 white voters, 264 black voters and 268 Hispanic voters); CBS NEws EXIT POLL 1988, supra note 277 (national file) (surveying 856 white voters, 210 black voters and 102 Hispanic voters); CBS NEWS EXIT POLL 1984, supra note 277 (national file) (surveying 693 white voters, 215 black voters and 121 Hispanic voters).

Asian-Americans were not included as a separate category in the 1984 or 1988 CBS general election polls. In 1992, Asian-Americans in California were split among the three candidates, with $39 \%$ voting for Clinton, $39 \%$ for Bush, and $22 \%$ for Perot. My calculations are based on data contained in GENERAL ELECTION EXIT POLL 1992, supra note 276 (California file) (surveying 81 Asian-American voters).

314. Thomburg v. Gingles, 478 U.S. 30, 48-49 (1986) ("Stated succinctly, a bloc voting majority must usually be able to defeat candidates sponsored by a politically cohesive, geographically insular minority group."); see also Johnson v. De Grandy, 114 S. Ct. 2647, 2657 (1994) (quoting same language). 
election does not necessarily prove that the district did not experience polarized voting in that election; special circumstances ... may explain minority electoral success in a polarized contest." ${ }^{315}$

The unusual three-way race of 1992 provides a good example of the kind of "special circumstances" that can influence the outcome of a particular election. Whereas, in 1984 and 1988, a solid majority of whites voted Republican, in 1992, white voters were split between three candidates. Bill Clinton received roughly the same percentage of the white vote as Michael Dukakis did in 1988, but was able to win because of this split. Thus, even though the majority of whites did not vote for the minority-preferred candidate, his margin of support among whites was high enough to enable him to win a three-way race. Since three-way races are, for the moment, an anomaly in presidential politics, and since the Republican candidate has won California in every other presidential election since 1968 , the pattern strongly suggests that the minority-preferred candidate usually loses.

The underlying problem is that, in California, white support for the Republican candidates, while far from unanimous, is strong enough to negate the African-American vote. If white "crossover" voting for Democrats were stronger, African-Americans might potentially be able to act as a bloc of swing voters, pushing the election one way or the other. However, the results of the 1984 and 1988 elections suggest that, in a two-way race, there simply are not enough African-Americans to affect the outcome in a winner-take-all race. ${ }^{316}$

\section{Illinois}

Illinois has historically been a bellwether state in American presidential elections. It has voted for the winning presidential candidate in every presidential election for the last 100 years, with two significant exceptions: Jimmy Carter in 1976 and Woodrow Wilson in 1916. From a political standpoint, then, it is in some ways similar to California, functioning as an important "swing" state. With twenty-two electoral votes, it is currently the fifth largest state, after California, New York, Texas, and Pennsylvania.

315. Gingles, 478 U.S. at 57. The Court cited the absence of an opponent, incumbency, and the utilization of bullet voting as factors that might constitute special circumstances, but cautioned that this list is "illustrative, not exclusive." Id. at 57 n.26.

316. Furthermore, the general election results may not reflect the true level of racially polarized voting, since none of these elections offered minority voters an opportunity to support a viable minority candidate. If, for example, Jesse Jackson had run as a third-party candidate in any of these elections, the primary election exit polls suggest that he might have received overwhelming black support, but almost no white support.

Indeed, the fact that there are no general elections involving minority candidates itself suggests that there is a problem. In a state where voting is polarized along racial lines, the winner-take-all rule tends to discourage members of racial minorities from running as third-party candidates. since they have little hope of winning the plurality that they need to gain a seat in the electoral college. 
Like those states, Illinois has a large African-American population. The 1990 census indicates that $13.3 \%$ of the state's VAP is African-American and $6.8 \%$ is Hispanic. ${ }^{317}$ Of the state's twenty congressional districts, three-or $15 \%$ - have African-American voting-age majorities, and one-or 5\%-has a Hispanic voting-age majority. ${ }^{318}$ The number of districts each group controls is thus roughly proportional to its percentage of the state's VAP. Illinois therefore clearly satisfies the first Gingles factor in either its traditional formulation or the alternative formulation with respect to both AfricanAmerican and Hispanic voters.

Again, it is difficult to draw any clear conclusions about the cohesiveness of Hispanic voters in Illinois elections. African-American voters, however, are strongly cohesive-perhaps slightly more so than in California. Exit polls indicate that Jesse Jackson was the overwhelming favorite among black voters in the 1984 and 1988 primaries, garnering $81 \%$ of the black vote in his first bid for the Democratic nomination and $90 \%$ in his second. By contrast, Jackson won only $3 \%$ of the white vote in 1984 and $7 \%$ in $1988 .{ }^{319}$ The past three general elections also show signs of racially polarized voting:

\begin{tabular}{||l|l|c|c||}
\hline \hline \multicolumn{2}{||c|}{} & $\begin{array}{c}\text { White } \\
\text { Vote }\end{array}$ & $\begin{array}{c}\text { Black } \\
\text { Vote }\end{array}$ \\
\hline \multirow{2}{*}{1984} & Walter Mondale & $33 \%$ & $96 \%$ \\
\cline { 2 - 4 } & Ronald Reagan & $65 \%$ & $0 \%$ \\
\hline \multirow{2}{*}{1988} & Michael Dukakis & $36 \%$ & $88 \%$ \\
\cline { 2 - 4 } & George Bush & $63 \%$ & $13 \%$ \\
\hline \multirow{3}{*}{1992} & Bill Clinton & $42 \%$ & $88 \%$ \\
\cline { 2 - 4 } & George Bush & $38 \%$ & $5 \%$ \\
\cline { 2 - 4 } & Ross Perot & $18 \%$ & $4 \%$ \\
\hline
\end{tabular}

TABLE 4. Illinois Election Results by Race ${ }^{320}$

317. ELECTION DATA BOOK, supra note 299 , at 7.

318. Id. at 271.

319. My calculations are based on data contained in CBS NEWS PRIMARY ELECTION EXIT POLLS 1984, supra note 302 (Illinois file) (surveying 937 white voters and 280 black voters); CBS NEWS PRIMARY ELECTION EXIT POLLS 1988, supra note 312 (Illinois file) (surveying I196 white voters and 374 black voters).

320. My calculations are based on data contained in GENERAL ELECTION EXIT POLL 1992, supra note 276 (Illinois file) (surveying 1402 white voters and 232 black voters); CBS NEWS EXIT POLL 1988, supra note 277 (national file) (surveying 528 white voters and 69 black voters); CBS NEWS ExIT POLL 1984, supra note 277 (national file) (surveying 432 white voters and 83 black voters). 
With respect to the white bloc voting prong of Gingles, Illinois appears very similar to California. The only recent election in which minority voters have been able to elect presidential electors is the three-way race of 1992. In that election, the white vote split between the three candidates, allowing Bill Clinton to win the state. That race, however, is clearly something of an anomaly, given the fact that Republicans have won the state in two-way races in every other election since 1968 . Based on the 1984 and 1988 results, white support for the Republican candidate is extremely high, and in neither of these elections did black voters operate as a swing constituency. Thus, the pattern of election results in Illinois suggests that it is really the white voters whose choices determine the outcome of the election. Again, African-Americans can vote, but their votes do not play any role in determining the outcome of the election.

\section{New York}

New York, unlike either California or Illinois, is frequently considered a Democratic bastion. Although Ronald Reagan won the state in 1980 and 1984, New York was the only big state to vote for Michael Dukakis in 1988, and Bill Clinton carried it handily in 1992. In those two most recent elections, minority voters arguably did elect the candidates of their choice. Thus New York, at first glance, would appear to be much less vulnerable to a $\S 2$ challenge.

Nonetheless, like the other states considered thus far, New York satisfies the first Gingles factor fairly easily. The 1990 census indicates that the state's population is $71.5 \%$ non-Hispanic white, $13.3 \%$ African-American, and $11.2 \%$ Hispanic. ${ }^{321}$ Of the state's thirty-one congressional districts, three have African-American voting-age majorities, and two have Hispanic majorities. In another two districts, no single racial or ethnic group constitutes a majority, but African-Americans and Hispanics combined do form a voting-age majority. ${ }^{322}$ Using either the traditional formulation or the proportional alternative, it is therefore clear that minority voters could control the choice of several presidential electors in a non-winner-take-all system.

New York elections also show strong signs of African-American political cohesion. Jesse Jackson received $85 \%$ of the black vote in 1984, but only $6 \%$

321. Election DATA BOoK, supra note 299 , at 7.

322. Id. 
of the white vote. ${ }^{323}$ And in 1988, he received $93 \%$ of the black vote, and $15 \%$ of the white vote. ${ }^{324}$ (Jackson also ran strongly among New York's Hispanic voters-largely Puerto Ricans-in the 1988 race, receiving $61 \%$ of the Hispanic vote. $)^{325}$

An exit poll in the 1988 primary also asked Democrats how they would vote in three hypothetical general election matchups: Dukakis vs. Bush, Gore vs. Bush, and Jackson vs. Bush. The disparities between white and black voters in response to these questions are highly suggestive of a pattern of racially polarized voting. When asked to choose between Jackson and Bush, $36 \%$ of white Democrats said they would vote for Bush, and only $33 \%$ said they would vote for Jackson. ${ }^{326}$ Among black Democrats, $86 \%$ said they would vote for Jackson, and only $3 \%$ said they would vote for Bush. ${ }^{327}$ But when asked to choose between Dukakis and Bush, $79 \%$ of white Democrats said they would vote for Dukakis and only $11 \%$ said they would vote for Bush. Similarly, when asked to choose between Gore and Bush, $61 \%$ of white Democrats said they would vote for Gore, and only $16 \%$ said they would vote for Bush. ${ }^{328}$ Black Democrats, however, showed no inclination to vote for Bush under any circumstances. Only $5 \%$ of respondents said they would vote for Bush in a Dukakis-Bush race, and only $8 \%$ said they would vote for him in a Gore-Bush race. ${ }^{329}$ These figures do not just demonstrate that black and white Democrats have different presidential preferences. They suggest that those preferences, along with the degree of party loyalty that a Democratic candidate in New York can expect, are closely tied to that candidate's race. In the 1988 election, at least, white Democrats in that state would have preferred to cross party lines or to sit the election out entirely, rather than vote for the lone African-American in the race.

323. My calculations are based on data contained in CBS NEWS PRIMARY ELECTION EXIT POLLS 1984, supra note 302 (New York file) (surveying 1483 white voters and 400 black voters).

324. My calculations are based on data contained in CBS NEWS PRIMARY ELECTION EXIT POLLS 1988, supra note 312 (New York file) (surveying 1482 white voters and 491 black voters).

325. My calculations are based on data contained in $i d$. (surveying 80 Hispanic voters).

326. My calculations are based on data contained in id. (surveying 1482 white voters and 491 black voters). In response to this question, $19 \%$ of white Democrats said they would not vote. Id.

327. Id. Only $2 \%$ of black respondents said they would not vote in a Bush-Jackson race. Another $9 \%$ failed to answer the question, which was on the back of the questionnaire.

328. Id.

329. Id. 
With respect to the white bloc voting prong of Gingles, however, New York presents a somewhat different picture than either California or Illinois:

\begin{tabular}{|c|l|c|c|}
\hline \hline \multicolumn{2}{|c|}{} & $\begin{array}{c}\text { White } \\
\text { Vote }\end{array}$ & $\begin{array}{c}\text { Black } \\
\text { Vote }\end{array}$ \\
\hline \multirow{3}{*}{1984} & Walter Mondale & $45 \%$ & $94 \%$ \\
\cline { 2 - 4 } & Ronald Reagan & $54 \%$ & $6 \%$ \\
\hline \multirow{3}{*}{1988} & Michael Dukakis & $47 \%$ & $85 \%$ \\
\cline { 2 - 4 } & George Bush & $53 \%$ & $10 \%$ \\
\hline \multirow{3}{*}{1992} & Bill Clinton & $45 \%$ & $85 \%$ \\
\cline { 2 - 4 } & George Bush & $36 \%$ & $8 \%$ \\
\cline { 2 - 4 } & Ross Perot & $17 \%$ & $6 \%$ \\
\hline
\end{tabular}

TABLE 5. New York Election Results by Race R30 $^{330}$

As in both California and Illinois, white voters in New York tended to favor the Republican candidate in both the 1984 and 1988 races. The margin of support among these voters for the Republican candidate, however, was much smaller: 54\% for Ronald Reagan in 1984, compared with $65 \%$ in Illinois and $64 \%$ in California, and $53 \%$ for George Bush in 1988, compared with $63 \%$ in Illinois and $57 \%$ in California.

The generally higher level of white support for the minority-preferred candidates in New York indicates that it should be easier for African-American voters in that state to choose presidential electors. The results of the 1988 election confirm this. In New York, as in California and Illinois, George Bush was the favorite among white voters, though only by a slim margin. Nonetheless, he lost the state, in large part because of the overwhelming support of African-American voters for Michael Dukakis. Thus in this election, African-American voters did function as a swing constituency, and their votes were not irrelevant to the outcome of the election. Taken in conjunction with the results of the 1992 election, the evidence of a pattern of vote dilution seems much weaker than it does in either California or Illinois.

This sort of $\S 2$ analysis might seem unfair from a purely partisan standpoint. One likely short-term effect of a successful vote-dilution case in the South would be to peel a few electoral votes away from the Republicans and place them in the Democratic column. It would certainly seem anomalous if

330. My calculations are based on data contained in GENERAL ELECTION EXIT POLL 1992, supra note 276 (New York file) (surveying 1676 white voters and 172 black voters); CBS NEWS EXIT POLL 1988, supra note 277 (national file) (surveying 473 white voters and 88 black voters); CBS NEWS EXIT POLL 1984, supra note 277 (national file) (surveying 611 white voters and 109 black voters). 
courts were unwilling to make a finding of vote dilution in New York, which has tended to vote Democratic. It is important to remember, however, that partisan fairness is not the object of $\S 2$. Instead, the statute is expressly directed toward racial discrimination in voting. What makes New York different from California or Illinois is not that it votes Democratic, but that its level of racially polarized voting is much less severe.

\section{REMEDIES}

The preceding analysis indicates that severe racially polarized voting is a hallmark of presidential elections in states throughout the nation. Moreover, in many states, this racially polarized voting works in combination with the winner-take-all system to deny minority voters any opportunity to choose presidential electors-a clear violation of $\S 2$. But what is the proper remedy for this vote dilution? Under the prevailing $\S 2$ analytical framework, this question is difficult to answer. The Gingles test presumes that courts will address vote dilution in at-large voting schemes by dividing states up into congressional districts, with a single elector representing each district. But states are unlikely to favor a pure single-member-district system as a means of choosing presidential electors, for reasons already discussed..$^{331}$

In an age in which citizens are accustomed to voting for President, legislative appointment is no longer a viable system for choosing electors. ${ }^{332}$ That leaves two basic remedial possibilities: the congressional-district system and the proportional system. The congressional-district system is in many ways similar to the single-member-district system, but it retains an at-large component and it does not require states to develop new districting plans. Under this system, each congressional district would choose one presidential elector, and an additional two would be chosen according to the statewide vote. In a proportional system, electors would be allocated to the various candidates according to their statewide popular vote. ${ }^{333}$ As we shall see, each of these

331. See supra Section II.B.

332. Furthermore, a state's decision to resort to legislative appointment specifically to avoid compliance with the Voting Rights Act would be highly questionable, reminiscent of the decision by some Southern counties to close their public schools rather than comply with the integration decrees of the federal courts. See Griffin v. County Sch. Bd., 377 U.S. 218 (1964). In states covered by $\$ 5$ of the Voting Rights Act, such a move would require preclearance either from the Justice Department or from the U.S District Court for the District of Columbia.

333. The proportional system that this Article envisions works as follows: The total number of votes cast in a state would be divided by the number of electoral votes to which that state is entitled, yielding a threshold figure. Each candidate's vote total could then be uniquely expressed as a constant multiplied by the threshold figure, plus a remainder, where the remainder would be smaller than the threshold. Each candidate would then be entitled to a number of electors equal to that constant, and any remaining electors would be allotted to the candidates with the greatest remainders.

As an example, assume that in a state with 10 electoral votes, 1000 votes are cast. Candidate $A$ receives 320 votes, candidate $B$ receives 545 votes, and candidate $C$ receives 135 votes. Candidate $A$ would then be entitled to three electors, B to six, and $C$ to one. On the other hand, if B received 535 votes and $\mathrm{C}$ received 145 , then $\mathrm{B}$ would get only five electors and $\mathrm{C}$ would get two. 
systems has its own virtues and defects. From a Voting Rights Act perspective, however, either method is superior to the winner-take-all system.

One point needs to be reemphasized here. Article II of the Constitution specifically vests the states with the power to choose the manner of appointment of presidential electors. ${ }^{334}$ While I have argued that Congress has authority to place limits on state discretion over the appointment of electors, it is important to recognize that Congress may not entirely supersede that discretion by requiring a particular mode of election. ${ }^{335}$ Federal courts, therefore, should ordinarily allow states to choose the remedy they feel is most appropriate-provided, of course, that it sufficiently addresses the $\S 2$ violation.

\section{A. The Congressional-District System}

One of the principal virtues of the congressional-district system is that it is firmly rooted in historical precedent. Prior to 1836 , at least one state selected electors by the district method in every presidential election, ${ }^{336}$ and two states-Maine and Nebraska-use it today. ${ }^{337}$ One recent commentator on the electoral college has argued that more states should be encouraged to adopt the congressional-district system, as a superior alternative to a direct vote. ${ }^{338}$ Moreover, the Supreme Court has expressly upheld the constitutionality of the congressional-district system, ${ }^{339}$ and good historical evidence suggests that the Framers contemplated that a district system would be the prevalent mode of election in states that instituted a popular vote. ${ }^{340}$ Finally, the congressional-district system is, at its root, little different from the singlemember-district electoral schemes that are familiar to most Americans.

From a Voting Rights Act perspective, the greatest strength of the district system as a remedy is that it can be tailored specifically to address racial minorities' vote dilution, rather than barriers faced by other minority political interest groups. In a majority-black district, African-American voters would be able to elect a presidential elector of their choice. Other interest groups-such as environmentalists or anti-tax protesters-would enjoy no such protection, since states typically do not draw congressional-district lines so as to give those groups a majority. Indeed, under the Voting Rights Act as currently

334. See U.S. CONST. art. II, \$ 1, cl. 2.

335. See supra Section III.A.

336. PEIRCE \& LONGLEY, supra note 3, at 247.

337. See supra note 42 and accompanying text.

338. See GLENNON, supra note 24, at 74-75. Interestingly, the congressional-district system was also supported by some Southem segregationists after the failure of the free-elector movement of 1960 . See JEANSONNE, supra note 66 , at 323-25.

339. See McPherson v. Blacker, 146 U.S. I (1892); see also supra notes 146-51 and accompanying text.

340. See Peirce \& Longley, supra note 3, at $45-46$ (noting that Jefferson, Hamilton, Madison, Andrew Jackson, John Quincy Adams, and Daniel Webster favored congressional-district system). 
interpreted, states have an obligation to draw congressional districts in a way that does not dilute minority voting strength.

The corresponding defect in the district system is that it is potentially inadequate as a remedy. The problem lies in the fact that each state has two more electoral votes than it does congressional districts. The district system addresses this disparity by providing that two electors will be chosen statewide. Thus, for two of a state's electoral votes, a winner-take-all system would be in effect. To the extent that the winner-take-all system dilutes minority voting strength, the district system would retain a discriminatory component. Hence the remedy would be incomplete.

How severe is the dilutive impact of those two statewide votes? Like any question of vote dilution, that depends on the circumstances. Although singlemember districts are the preferred remedy for dilutive at-large systems, courts have often approved "hybrid" remedial plans that involve some combination of district-based and at-large voting. One objective factor that is critical to any assessment of the district system as a remedy is the size of the state. The smaller the state, the fewer congressional districts it will have. Consequently, the two statewide electoral votes will constitute a larger portion of the state's electoral vote. Under a district system in Alabama, two-ninths of the state's electoral votes would be chosen statewide. In New York, only two-thirty-thirds would be chosen statewide. Hence the discriminatory impact of the district system would be smaller. This suggests that the district system may be a more appropriate remedy for large states than for smaller ones.

Another potential flaw of the district system is that it depends on the existence of viable majority-minority districts. If there are no such districts, the system will not work. In the 1990 s, states have gone to great lengths to draw majority-minority congressional districts. During the past two years, however, courts have struck down several of these districts as unconstitutional "racial gerrymanders." ${ }^{341}$ The Supreme Court's recent decision in Miller $v$. Johnson, ${ }^{342}$ holding that Georgia's congressional districts violated the Equal Protection Clause, now threatens to place severe limits on the ability of states to create majority-minority districts. Without such districts, the congressionaldistrict system will cease to be fully effective as a remedy.

The district system may also be problematic in states with two or more distinct minority groups. Redistricting efforts in those states are sometimes characterized by competition between minority groups. In Florida voting rights cases, for example, courts have documented a "keen hostility" between African-American and Hispanic voters. ${ }^{343}$ In such a situation, a court's or a legislature's decision to draw a majority-minority district for one group may

341. See Miller v. Johnson, 115 S. Ct. 2475, 2483, 2494 (1995); Vera v. Richards, 861 F. Supp. 1304, 1309, 1311 n.7 (S.D. Tex. 1994), prob. juris. noted sub nom. Bush v. Vera, 115 S. Ct. 2639 (1995).

342. 115 S. Ct. 2475 (1995).

343. See Meek v. Metropolitan Dade County, 985 F.2d 1471, 1481-82 (11th Cir. 1993). 
result in a failure to draw a majority-minority district for another group. ${ }^{344}$ California, for example, has five majority-Hispanic districts, but no majorityAfrican-American districts, despite a significant African-American voting-age population. ${ }^{345}$

\section{B. The Proportional System}

The proportional system of choosing presidential electors has been advocated by various reformers for more than a century. ${ }^{346}$ Its basic virtue is its fairness. A proportional system treats every voter within a state almost exactly alike. ${ }^{347}$ The dilutive effect of the two at-large seats is eliminated. Every voter has roughly the same ability as every other voter in that state to influence the outcome of the election. ${ }^{348}$ By contrast, even the fairest possible district system results in significant inequalities among voters. Congressional districts, for example, must be roughly equal in total population. The number of eligible voters in each district may vary significantly, and the proportion of those voters who actually vote in any given election may fluctuate wildly. Furthermore, the district system requires states to manipulate district lines in order to achieve a racially "fair" result-a process that clearly has left a bitter taste in the mouths of many of the Justices.

The principal virtue of the proportional system is also its greatest defect as a $\S 2$ remedy. Where the district system is carefully tailored to address the effects of racial vote dilution, the proportional system is wildly overbroad. It potentially would allow members of any cohesive political minority-not just racial minorities - within a state to gain a seat in that state's electoral college. Environmentalists, anti-abortion activists, gay rights groups, and white supremacists all could benefit, as could numerous other political special interest groups.

The three-way election of 1992 illustrates this problem. In that race, independent candidate Ross Perot garnered $19 \%$ of the vote nationwide.

344. See De Grandy v. Wetherell, 815 F. Supp. 1550, 1578 (N.D. Fla. 1992) (three-judge court) (finding that remedy for Hispanic vote-dilution claim and remedy for African-American vote-dilution claim were mutually exclusive), aff'd in part and rev'd in part sub nom. Johnson v. De Grandy, 114 S. Ct. 2647 (1994).

345. ConGResSIONAL DISTRICTS IN THE 1990s, supra note 216, at 57-58. The most heavily black districts in California have $44.0 \%$ and $39.9 \%$ African-American voting-age pluralities, respectively. Id.

346. See PEIRCE \& LONGLEY, supra note 3, at 144-57 (detailing proposals to adopt proportional system by constitutional amendment from 1878 through 1960s). For a 1926 proposal urging adoption of the proportional system, written by two advocates of proportional representation, see HOAG \& HALLETT, supra note 143 , at 320-28.

347. Because electoral votes cannot be divided, the "proportional method" will not produce exact proportionality, but only rough proportionality. See discussion supra note 333 . In theory, these variations might be thought to violate the one-person-one-vote rule mandated by the Equal Protection Clause. The Supreme Court, however, has never interpreted this Clause to require absolute equality of votes.

348. Voters in different states, of course, would not have equal voting power. See Banzhaf, supra note 39 , at 318-19. This is a basic inequality that cannot be changed without a constitutional amendment. 
Because of the prevalence of the winner-take-all system, however, he failed to receive a single electoral vote. (Ironically, Perot had his best showing in Maine, one of the two states that does not employ the winner-take-all system.) Bill Clinton won the election with 370 electoral votes to George Bush's 168. A congressional-district scheme would have led to a similar result. Perot did not win any of the nation's 435 congressional districts. Clinton won 32 states, or 257 districts, as well as the District of Columbia. Bush won the remaining 18 states, or 178 congressional districts. ${ }^{349}$ Under a congressional-district scheme, then, Clinton would have received 324 electoral votes to Bush's 214. Perot, once again, would have gotten nothing.

Under a proportional system, however, the fifty states and the District of Columbia would have appointed 197 Bush electors, 236 Clinton electors, and 105 Perot electors. ${ }^{350}$ These results would be roughly proportional to the nationwide popular vote. But while this might be a more democratic alternative, it certainly is not what Congress had in mind when it passed the 1982 amendments to $\S 2$. The Voting Rights Act exists specifically for the benefit of racial and language minorities, not to help political special interest groups more generally. The proportional system would thus potentially reach much further than Congress ever intended.

How serious a flaw is the overbreadth problem? Again, that depends on specific factual circumstances, most notably the size of the state. One of the key limitations on the electoral system is that it depends on actual electors to cast votes. Thus there can be no fractional votes. In this respect, the smaller the state, the more difficult it will be for a political fringe group to capture an electoral college seat. In a state with 40 electoral votes, for example, a candidate receiving $2.5 \%$ of the vote would be entitled to one elector. In a state with 10 electoral votes, that same candidate might need to receive as much as $10 \%$ of the vote. ${ }^{351}$ This places an important limitation on the ability of fringe groups to receive votes in small states, but not in large ones, suggesting that the proportional system might be appropriate in Alabama or Mississippi, but not in California or New York.

349. Alice V. MCGILlivraY \& RichaRd M. SCAMMON, AMERICA AT THE POLLS, 1960-1992, at 3 (1994) (reporting state-by-state election results); Cohen, supra note 273, at 1285 (reporting results of 1992 election by district).

350. My calculations are based on election results reported in MCGILLIVRAY \& SCAMMON, supra note 349 , at 3 .

The distinction between electors and electoral votes is crucial here, since it is by no means certain that all of these electors would vote as planned under these circumstances. In this situation, Perot might well have chosen to throw his electors to one candidate or the other, in exchange for particular concessions. Alternatively, he might have released them to vote as they pleased. If the electors were to vote faithfully, however, each candidate would have received roughly the same percentage of the electoral vote as he did of the popular vote. No one candidate would have had a majority, and the election would have gone to the House.

351. Under the proportional system I have described, a group might be able to capture a single elector with less than $10 \%$ of the vote. However, it would need to receive at least $10 \%$ to be assured of getting one elector. 
Of course, given a choice between the two systems, one might expect that most states would opt for a congressional-district scheme. Several factors suggest this conclusion. First, the congressional-district system allows a state to keep a bloc of two statewide votes, thus increasing that state's influence in the electoral college, if only marginally. As Akhil Amar and Vik Amar have argued, the dominance of the winner-take-all scheme can largely be attributed to a "prisoners' dilemma." No state wants to be the first to break up its bloc of electoral votes. ${ }^{352}$ Thus, the same factors that have led states to prefer the winner-take-all system over the congressional-district system might lead them to favor the congressional-district system over the proportional system. Second, the congressional-district system would tend to be less disruptive of the existing two-party system. The two major political parties are therefore likely to see it as less of a threat.

Nonetheless, the potential defects of a congressional-district scheme as a remedial plan in a small Southern state are worrisome. In those states, courts should be extremely wary of approving the congressional-district method as a $\$ 2$ remedy because of its potentially dilutive effect. I have previously argued that, under Article II, states may not be compelled to adopt a particular remedial scheme. It would therefore be inappropriate for a court to mandate that Alabama, Mississippi, and similarly situated states adopt a proportional system, on the grounds that it would provide the most complete remedy for minority vote dilution. It might not be inappropriate, however, for a court to find that the congressional-district system would not afford a complete remedy, leaving the state with the alternative of instituting a proportional district system, a pure single-member-district scheme, or a legislative-appointment scheme. ${ }^{353}$ Given this choice, states would be likely to opt for the proportional scheme, for reasons I have already described. Nonetheless, a court's decision to offer such a limited menu of remedial options would clearly be treading very close to the constitutional boundary line set by Article II.

\section{RETHINKING WINNER-TAKE-ALL: SOME POSSIBLE EFFECTS}

The analysis in the preceding part suggests that different methods of choosing presidential electors might be appropriate in different states. Several states, for example, are immune from $\S 2$ challenge because they do not have enough minority voters to enable them to satisfy the Gingles numerosity requirement. These states have a strong incentive to retain the winner-take-all system. The smaller Southern states might conceivably be compelled to adopt the proportional method, while the largest states-California, New York,

352. See Amar \& Amar, supra note 40, at 927-29.

353. See supra Section V.A. A pure single-member-district scheme would eliminate the dilutive effect of the two at-large seats involved in the congressional-district scheme. 
Texas, and so on-might prefer to adopt the congressional-district system. The result would be not a uniform plan, but a patchwork of different plans in different states.

What effect would such a system have on our political culture? If the experience of the Framers teaches us anything, it is that we should be wary of making such predictions. As we have seen, the Framers initially failed to anticipate the development of a national two-party system, leading to a serious breakdown of the electoral machinery in the election of $1800 .{ }^{354}$ Changes in complex systems invariably bring about results that cannot be predicted with any degree of accuracy. Nonetheless, it is possible to hazard some rough guesses about the effects that a move away from the winner-take-all system might have on the American political system.

\section{A. Political Realignments}

The short-term partisan beneficiaries of the patchwork system I have described would likely be the Democrats. Elimination of the winner-take-all rule in the South would tend to peel some electoral votes away from the Republicans and place them in the Democratic column. Whether such an effect would continue into the long term, however, is uncertain. A move to a proportional system in the South, for example, might give Republican presidential candidates an incentive to court African-American voters more aggressively, while encouraging Democratic candidates to be less protective of their base. A moderation in the racial policies of the two major parties could lead to a significant political realignment. ${ }^{355}$

Alternatively, a move away from the winner-take-all system might give minority voters an incentive to break away from the Democratic party and run their own candidates for President. The formation of a new political party to represent minority interests might serve to further weaken the Democrats in presidential contests.

Of course, there can only be one President at any given time. And it is highly unlikely that a third party representing minority political interests would ever be able to attract enough support to allow its candidate to win the Presidency. But in a close election, a minority political party might be able to elect enough presidential electors to deprive either of the major-party

354. See supra note 33.

355. See EDSALL, supra note 60 , at 30 :

Partisan competition for the votes of black America has been absent for over a generation, and its absence has corrupted both parties. For the Democratic party, a secure base of support among black voters has stiffed innovation, and has eliminated pressure to develop policies that productively reinforce the loyalty of the party's most reliable electorate. The GOP, in turn, has built its success for the past twenty-five years on the basis of racial and cultural flight from the Democratic party, becoming in the process a de facto white party.

This lack of competition can be attributed in large part to the dominance of the winner-take-all system. 
candidates of an electoral majority. Electors from the minority party would then be in a position to throw their support to one major-party candidate or the other in exchange for particular political concessions: a Cabinet seat for their candidate, perhaps, or a promise to pursue particular legislative initiatives. In effect, this would be a variation on the strategy employed by George Wallace in $1968,{ }^{356}$ this time used to advance minority political interests rather than to stifle them. The concept of deal making between political parties to determine who will become President may seem alien to many Americans. Of course, similar arrangements take place all the time in multiparty parliamentary systems such as those in Europe. If we are to have a government that truly represents all of the people, we must be willing to accept some occasional accommodation of minority interests.

Critics of proportional representation systems frequently claim that efforts to accommodate multiple political interests tend to have a detrimental impact, producing political fragmentation and government instability. ${ }^{357}$ Although these charges may be overstated - certainly the sky has not fallen in Germany, Ireland, Australia, or many other democracies that incorporate an element of proportional representation ${ }^{358}$ - they represent important concerns about the kind of coalition governments that a hybrid electoral scheme might produce in a three-party race. ${ }^{359}$

With respect to our presidential election scheme, however, these concerns are somewhat misplaced. Presidential electors do not exercise any governmental function other than the selection of the President. The separation of their function from all of the other tasks of government is an integral part of the electoral scheme envisioned by the Framers. ${ }^{360}$ This tends to minimize the risk of government instability. Once the electors vote, they go home. Whether they choose a President or not, they exercise no further influence. In

356. See supra text accompanying note 114.

357. See, e.g., Peter H. Schuck, The Thickest Thicket: Partisan Gerrymandering and Judicial Regulation of Politics, 87 CoLUM. L. REV. 1325, 1363 (1987) (arguing that proportional representation produces "fragmenting effect on the party system and the legislative process, ... encouragement of ideological, single-issue political appeals, ... promotion of coalition govemment and instability, and ... relative unresponsiveness to local constituents and individual voters' needs").

358. See, e.g., Maurice Duverger, Duverger's Law: Forty Years Later, in Electoral LawS AND THEIR POLITICAL CONSEQUENCES, supra note 130, at 69,71-76 (noting tendency toward two-party system despite elements of proportional representation in West Germany, Austria, and Ireland); Peter Mair, Districting Choices under the Single-Transferable Vote, in EleCTORAL LAWS AND THEIR POLITICAL CONSEQUENCES, supra note 130, at 289, 294-99 (discussing stability of PR government in Ireland); Jack F.H. Wright, Australian Experience with Majority-Preferential and Quota-Preferential Systems, in ELECTORAL LAWS AND THEIR POLITICAL CONSEQUENCES, supra note 130, at 124, 134-37 (noting that proportional representation methods probably reduce confrontational style of politics). With the exception of France and Britain, every single European democracy now includes some element of proportional representation in its parliament. MATTHEW COSSOLOTO, THE ALMANAC OF EUROPEAN POLITICS 1995, at 4 (1995).

359. For a response to the most common objections to proportional representation, see AMY, supra note 214, at 153-82.

360. See supra text accompanying note 25 . 
a typical parliamentary system, the government depends on the sustained support of the legislators for its continuance in office. By contrast, a new President chosen by a divided electoral college would still exercise all of the constitutional prerogatives of his office for the full duration of his term.

Furthermore, voters in this country are widely dissatisfied with the existing two-party system, as evidenced by the strong 1992 showing of Ross Perot. In one recent poll, 57\% of those surveyed said they favored creation of a third party to compete with the Democrats and Republicans. ${ }^{361}$ In keeping with this mood, Perot recently announced the formation of a new "Independence Party."362 The two-party model of government has been dominant for nearly two centuries in this country. Perhaps it is time for a different model of government-one that gives minority voters some voice in the executive branch.

My comments in this section should not be misconstrued. I am not advocating a system in which electors would exercise independent judgment. Such a system would run contrary both to common sense and American political tradition. Rather, I am suggesting that the candidates, in their capacities as representatives of the voters, might be able to strike deals after the popular vote for the support of their electors. Electors would then merely cast their votes according to the instructions of the candidate to whom they were pledged. ${ }^{363}$ Absent extraordinary circumstances, the electors would remain ciphers.

Nor am I suggesting that such deal making would, or should, become a commonplace occurrence in our presidential elections. Even if the winner-takeall system were to be abandoned in a large number of states, minority voters would only be in a position to affect the outcome of the election if the race were relatively close in the electoral college. Thus, in the typical election, minority voters might do much better by casting their lot with one of the two major parties than by running their own candidate. My suggestion here is that the mere possibility of a minority-backed candidate being able to attract electoral votes could significantly alter the dynamics of the American political system.

361. David Broder, Country May Be Ripe for a Third Party, DaLlas MORNing NEws, Apr. 23, 1995, at 5J; see also Debbie Howlett, 'Perot Movement' for Third Party Growing, USA ToDAY, Apr. 12, 1995, at $8 \mathrm{~A}$.

362. See, e.g., B. Drummond Ayres Jr., Perot is Starting Third-Party Drive, N.Y. Times, Sept. 26, 1995, at A1. It is as yet unclear whether this new organization, with its somewhat self-contradictory title, will function as a true political party or merely as a vehicle for Perot to seek the presidency a second time.

363. In many states, electors are pledged by either party rule or state law to vote for a particular candidate. In the system I am envisioning, these pledges would be slightly modified. Rather than pledging to vote for a candidate, electors would pledge to vote in accordance with that candidate's instructions. 


\section{B. Biases, "Wrong Winners," and the Direct-Vote Alternative}

No system of voting is perfect. A move away from the winner-take-all system would fail to remedy two of the most frequently criticized quirks of the current electoral system. First, under a winner-take-all system, voters in large states have a greater ability to affect the outcome of presidential races than do voters in small states. ${ }^{364}$ Under a proportional or a district system, that inequality would be reversed, and votes in small states would count for more than votes in large states. ${ }^{365}$ To some degree this might be an improvement, since the small states do not represent enough electoral votes to determine the outcome of elections on their own. Nonetheless, some inequality would remain.

Furthermore, a hybrid system would not ensure that the winner of the popular vote would always be elected President. Quite the opposite, in fact. By encouraging third-party candidates to run, it might increase the possibility that a runner-up in the popular vote would receive a majority of the electoral vote. Under the winner-take-all system, this has happened at least twice, in the elections of 1876 and $1888 .{ }^{366}$ Whether this is actually a flaw is subject to debate. There can be no doubt, however, that a scheme designed to give minorities an effective voice in the selection of the President is fundamentally incompatible with a view of democracy premised on absolute majority rule.

These problems-to the extent that they are really problems-can be remedied, but only by a constitutional amendment to eliminate the electoral system entirely and substitute a direct popular vote for President. A direct vote would ensure that every voter would have the same opportunity-at least on

364. See Banzhaf, supra note 39 , at 306. Banzhaf demonstrates mathematically that any winner-take-all system will create inequalities among voters. This is not simply a consequence of the way in which votes are allocated among states, but derives from the fact that an individual voter's ability to influence the outcome of an election varies inversely with the square root of the state's population. Id. at 314 .

365. See id. at 319,321 . The inequalities under the congressional-district system and the proportional system arise from the fact that electoral votes are not allocated in proportion to population. Each state, large or small, is allowed to elect two Senators, and thus has two corresponding electoral votes. Banzhaf notes that if electoral votes were allocated on a strict population basis, the inequalities in the proportional system would disappear. Id. at 319. That analysis is not entirely accurate, however, because it assumes that everyone counted in the population will actually vote or will vote at the same rate in every state. For extensive criticisms of the winner-take-all rule, see ABBOTT \& LEVINE, supra note 3; PEIRCE \& LONGLEY, supra note 3.

366. ABBoTT \& LEVINE, supra note 3, at 25-26. John Quincy Adams, who won a House contingency election in 1824, finished second in both the electoral and the popular vote. Since many states still employed legislative selection of electors at that time, id. at 51, the popular vote did not reflect the preferences of the entire electorate.

The 1960 election may also have produced a "wrong winner"-to use the somewhat loaded term employed by Abbott and Levine. Because of the difficulty in interpreting votes cast for uncommitted electors in Alabama, the popular vote total that John F. Kennedy received is subject to dispute. See PEIRCE \& LONGLEY, supra note 3, at 65-67. Under either a proportional system or a district system, Nixon would have defeated Kennedy in 1960. ABBOTT \& LEVINE, supra note 3, at 123; PEIRCE \& LONGLEY, supra note 3, app.M at 294-95. A proportional system would have produced "wrong winner" outcomes in 1880 and 1896 , but not in 1876 or 1888 . Id. app.M at 294 . Figures on the district system are not available prior to 1952. In 1976, however, a district system would have created an electoral college tie between Jimmy Carter and Gerald Ford. Id. app.M at 295. 
paper-to influence the outcome of an election, and it would ensure that the popular vote winner would always be elected President.

No electoral system, however, is perfect. Many arguments against the direct-vote scheme have been made, and they need not be repeated here. ${ }^{367}$ But one point requires special emphasis because it relates directly to the question of minority vote dilution. As a result of the strong patterns of racially polarized voting in presidential elections, a direct vote could work to minimize minority voting strength almost as severely as the winner-take-all system. This problem is illustrated by the facts of Holder v. Hall, ${ }^{368}$ the recent Supreme Court case involving a challenge to a single-member-commissioner form of government in a rural Georgia county. ${ }^{369}$ In Holder, the Eleventh Circuit found that racially polarized voting prevented African-Americans from having any significant voice in the selection of their sole local governmental officer. Direct election of the President could have similar consequences. If voting continued to be polarized along racial lines, the white majority would always be able to choose the President. A direct vote might simply be a winner-takeall scheme on a national scale, in which African-Americans would be able to vote, but their votes would never affect the outcome.

\section{CONCLUSION}

The winner-take-all method now used to select presidential electors in forty-eight states and the District of Columbia severely dilutes AfricanAmerican voting power. In the Southern states, where racially polarized voting patterns are particularly intense, this system effectively denies minority voters an opportunity to choose even a single presidential elector. In effect, these voters have no voice in the selection of the President. Nor is this problem necessarily limited to the South-or to African-American voters. The winnertake-all system denies minority voters in states throughout the country a full and fair opportunity to participate in presidential elections.

In many states, this type of discriminatory voting system is not only undemocratic, but potentially illegal. The winner-take-all rule is precisely the kind of discriminatory electoral scheme that Congress had in mind when it amended $\S 2$ in 1982. Under the now-accepted statutory framework for analyzing $\S 2$ claims, twenty-one states are potentially susceptible to $\S 2$ challenges: Alabama, Arizona, California, Florida, Georgia, Illinois, Louisiana, Maryland, Michigan, Mississippi, Missouri, New Jersey, New Mexico, New York, North Carolina, Ohio, Pennsylvania, South Carolina, Tennessee, Texas, and Virginia. Altogether, these states appoint 361 of the 538 presidential

367. See GLENNON, supra note 24, at 73 (arguing that direct vote could unleash "chaos and potential for electoral fraud"); see also BEST, supra note 4; DIAMOND, supra note 16.

368. 114 S. Ct. 2581 (1994).

369. See supra Section III.B. 
electors. While the winner-take-all system is not necessarily illegal in all of these states, patterns of racially polarized voting across the country are remarkably constant, suggesting that many states are, at the very least, skirting the edge of the law.

There are at least two viable remedies for this problem: a proportional system of choosing electors and a system based on existing congressional districts. From a $\$ 2$ perspective, these methods have complementary strengths and weaknesses. The proportional remedy is more appropriate for smaller states, such as those in the South, while the congressional-district system is better suited to larger states. Except in the most extreme cases, however, established principles of equity dictate that states should have discretion to choose the appropriate remedy, subject to a court's determination that a proposed remedy will give minority voters an equal opportunity to participate in the selection of presidential electors.

Implementation of these remedies would likely have far-reaching effects on our political system. It would almost certainly lead to a significant political realignment, and possibly to the creation of one or more new political parties. The long-term effects of such a change are difficult to foresee.

Defenders of the status quo will doubtless point out that the alternative electoral schemes contemplated in this Article will undercut the principle of majority rule. This view is correct, but it is a critique premised on the notion that majority rule is the ultimate goal of democratic government. The very fact that we currently do not select a President in a manner that assures majority rule-witness the elections of 1876 and 1888-suggests that majority rule is merely one of many principles on which our democracy rests. The Framers recognized this, and provided for a form of government in which the interests of states were balanced with the interests of the people. The electoral college reflects this balancing act. Perhaps today's political climate calls for a different kind of balancing, based not on regional ties, but on recognition of the different interests that different segments of society have consistently expressed in voting booths across the nation. If administered in a fair and nondiscriminatory manner, the electoral college system might help us to find that balance. 


\section{.}

